\title{
Material Use in the United States- Selected Case Studies for Cadmium, Cobalt, Lithium, and Nickel in Rechargeable Batteries
}

Scientific Investigations Report 2008-5141 


\section{Material Use in the United States- Selected Case Studies for Cadmium, Cobalt, Lithium, and Nickel in Rechargeable Batteries}

By David R. Wilburn

Scientific Investigations Report 2008-5141 


\title{
U.S. Department of the Interior \\ KEN SALAZAR, Secretary
}

\author{
U.S. Geological Survey \\ Suzette M. Kimball, Acting Director
}

U.S. Geological Survey, Reston, Virginia: 2009

For more information on the USGS - the Federal source for science about the Earth, its natural and living resources, natural hazards, and the environment, visit http://www.usgs.gov or call 1-888-ASK-USGS

For an overview of USGS information products, including maps, imagery, and publications, visit http://www.usgs.gov/pubprod

To order this and other USGS information products, visit http://store.usgs.gov

Any use of trade, product, or firm names is for descriptive purposes only and does not imply endorsement by the U.S. Government.

Although this report is in the public domain, permission must be secured from the individual copyright owners to reproduce any copyrighted materials contained within this report.

Suggested citation:

Wilburn, D.R., 2008, Material use in the United States—Selected case studies for cadmium, cobalt, lithium, and nickel in rechargeable batteries: U.S. Geological Survey Scientific Investigations Report 2008-5141, 19 p. 


\section{Contents}

Abstract
Introduction.
Study Methodology
Case Study 1-Cell Phones
Case Study 2-Cameras and Camcorders
Case Study 3-Portable Computers
Case Study 4-Hybrid Vehicles
Summary and Conclusions
References Cited
Appendix

\section{Figures}

1. Graph showing percentage of global rechargeable battery sales for the principle battery types from 1994 through 2005 .

2. Graph showing U.S. cell phone subscription and import data compared with estimates for the number of cell phones available for disposal at the end of life

3. Graphs showing estimated U.S. net imports of cameras and camcorders by battery type

4. Graph showing estimated amounts of cadmium, cobalt, lithium, and nickel contained in rechargeable camera and camcorder batteries used in the United States from 1996 through 2005

5. Graph showing estimated imports of portable computers by battery type and amounts of cobalt, lithium, and nickel contained in rechargeable portable computer batteries used in the United States from 1996 through 2005.

\section{Tables}

1. Content of key material components contained in hybrid electric vehicle batteries

2. Reported U.S. apparent consumption for selected metals and the content of these metals in batteries used in popular consumer products for the period 1996 through 2005 


\section{Conversion Table}

\begin{tabular}{lcl}
\hline \multicolumn{1}{c}{ Multiply } & \multicolumn{1}{c}{ By } & \multicolumn{1}{c}{ To obtain } \\
\hline & \multicolumn{2}{c}{ Mass } \\
\hline ounce, avoirdupois $(\mathrm{oz})$ & 28.35 & gram $(\mathrm{g})$ \\
pound, avoirdupois $(\mathrm{lb})$ & 0.4536 & kilogram $(\mathrm{kg})$ \\
ton, short $(2,000 \mathrm{lb})$ & 0.9072 & megagram $(\mathrm{Mg})$ \\
\hline
\end{tabular}




\title{
Material Use in the United States-Selected Case Studies for Cadmium, Cobalt, Lithium, and Nickel in Rechargeable Batteries
}

\author{
By David R. Wilburn
}

\section{Abstract}

Consumer preferences, environmental regulations, new end-use markets, reduced production costs, and technological advances have contributed to the consumption and substitution patterns of rechargeable batteries, particularly in automotive and consumer electronic product applications; therefore, a thorough understanding of the use and disposal of the metals used in such batteries is warranted. Four case studies assessing the material use patterns for cadmium, cobalt, lithium, and nickel contained in cell phone, camera and camcorder, portable computer, and hybrid vehicle batteries were conducted for 1996 through 2005 based on an analysis of U.S. International Trade Commission trade data.

The cadmium content of camcorder, camera, and cell phone batteries used annually in the United States declined to about 7 metric tons (t) in 2005 from about $100 \mathrm{t}$ in 1995, as a result of the implementation of regulations affecting nickelcadmium battery recycling and disposal and the introduction of technological advancements in lithium-ion and nickelmetal-hydride (NiMH) batteries that are increasingly used as alternatives. An analysis of cell phone recycling data suggests that up to $91 \mathrm{t}$ of cadmium contained in cell phone batteries was available for recovery between 1996 and 2005. Some of this material resides in storage.

The cobalt content of rechargeable batteries used annually in camcorders and cameras, cell phones, and portable computers in the United States increased to about 2,300 $t$ in 2005 from $55 \mathrm{t}$ in 1996 because of increased demand and technological improvements that have reduced the cost of these products while making them more efficient. Analysis of cell phone data suggests that 410 t of cobalt may have been recovered from recycled cell phone batteries, and about 4,700 $\mathrm{t}$ of cobalt contained in cell phone batteries was available for recovery during the 10 -year study period.

The lithium content of rechargeable batteries used annually in consumer electronic products in the United States increased to about $290 \mathrm{t}$ in 2005 from about $87 \mathrm{t}$ in 1996. Estimates of U.S. lithium apparent consumption, which exclude products such as batteries that are contained in imported manufactured products, decreased during much of this period. Lithium used in cell phone batteries in the United States increased between 1996 and 2005 to about $170 \mathrm{t}$ in 2005 from $1.8 \mathrm{t}$ in 1996. Lithium used in portable computer batteries increased for this same period to about $99 \mathrm{t}$ in 2005 from $3.3 \mathrm{t}$ in 1996. Technological developments in camcorder and camera technology for the period had the net effect of reducing the lithium content per battery for these applications, but the increasing popularity of the digital camera led to an increase to 19 t of lithium in camera batteries in 2005 from 100 kilograms in 1996. Less than 10 t of lithium contained in cell phone batteries was recycled during the 1996-2005 period, suggesting that up to $580 \mathrm{t}$ of lithium in cell phone batteries was available for recovery, primarily after 2001 .

Nickel content in batteries used annually in camcorders and cameras, cell phones, and portable computers in the United States increased to about 3,000 t in 2005 from $280 \mathrm{t}$ in 1996, mostly a result of increased use of the NiMH battery in these applications. Estimates of nickel use in batteries for hybrid vehicles increased to 2,700 t in 2005 from a negligible amount in 1996. By the year 2010, it is estimated that the amount of nickel used in hybrid vehicle batteries could exceed 7,300 t. Cobalt content of hybrid vehicle batteries used in the United States is expected to reach about $210 \mathrm{t}$ in 2010. An analysis of cell phone recycling data suggests that about 410 t of nickel in batteries was recycled between 1996 and 2005; about 3,100 t was likely available for recovery, although some of this material resides in storage.

\section{Introduction}

This report examines the changes that have taken place in the consumer electronic product sector as they relate to the use of cadmium, cobalt, lithium, and nickel contained in batteries that power camcorders, cameras, cell phones, portable (laptop) computers and the use of nickel in vehicle batteries for the period 1996 through 2005 and discusses forecasted changes in their use patterns through 2010. Market penetration, material substitution, and technological improvements among nickel- 
cadmium (NiCd), nickel-metal-hydride (NiMH), and lithiumion (Li-ion) rechargeable batteries are assessed. Consequences of these changes in light of material consumption factors related to disposal, environmental effects, retail price, and serviceability are analyzed in a series of short case studies.

This study supplements U.S. Geological Survey (USGS) mineral commodity production and consumption statistics by providing estimates of the amount of materials consumed by important market sectors. It provides information that allows government, nongovernmental organizations, and the public to gain a better understanding of how much and where these materials are used and to draw inferences on how the substitution of different battery chemistries may affect the amount of these materials available for disposal or recycling. The study is part of a series of USGS materials flow assessments on cell phones (Sullivan, 2006), lead-acid batteries (Wilburn and Buckingham, 2006), and NiCd batteries (Wilburn, 2007) and draws in part on data collected for and estimates derived from these previous studies.

Environmental regulations, new end-use markets, and technological advances all have played a role in the changing consumption and substitution patterns of rechargeable batteries, particularly in automotive and consumer electronic product applications. Figure 1 illustrates how the nonautomotive rechargeable battery sector has changed since 1994. In 1994, NiCd batteries accounted for about 88 percent of the world market for rechargeable batteries in terms of the number of batteries sold. By 1999, the market share for NiCd batteries had dropped to below 50 percent, and the NiMH battery market share had grown to about 40 percent. By 2005, the market share of $\mathrm{NiCd}$ battery sales had declined to about 34 percent, the NiMH market share had decreased to about 23 percent, and a new battery technology - the Li-ion battery-had developed a market share of almost 40 percent.

In 2002, it was estimated that 350 million rechargeable batteries were purchased annually in the United States (U.S. Environmental Protection Agency, 2002a). The number of batteries has since increased to provide power for the increasing number of cell phones, portable (laptop) computers, and other electronic consumer products used in the United States. The large quantity of batteries in use makes a quantitative assessment of the use and flow of the mineral constituents contained in these batteries essential to understanding the level of risk to human health and the ecosystem associated with these materials.

Some materials contained in batteries can potentially cause harm to the environment and humans if they are manufactured, used, or discarded improperly. In 1992, the U.S. Environmental Protection Agency classified cadmium as a Group B1 probable human carcinogen (U.S. Environmental Protection Agency, 2000). In that same year, about 146,000 t of consumer batteries of all types, some of which contained cadmium, was discarded in the United States (Klimasauskas and others, 2006). NiCd batteries accounted for an estimated 75 percent of the cadmium found in U.S. municipal solid waste (MSW) landfills in 1995 (U.S. Environmental Protection Agency, 2002b); however, the leaching of cadmium into the soil over time from NiCd batteries that are deposited in properly designed landfills is mitigated by lining the landfills with impenetrable materials. In recognition of the potential environmental hazards associated with cadmium metal exposure, some States have limited cadmium use in some consumer

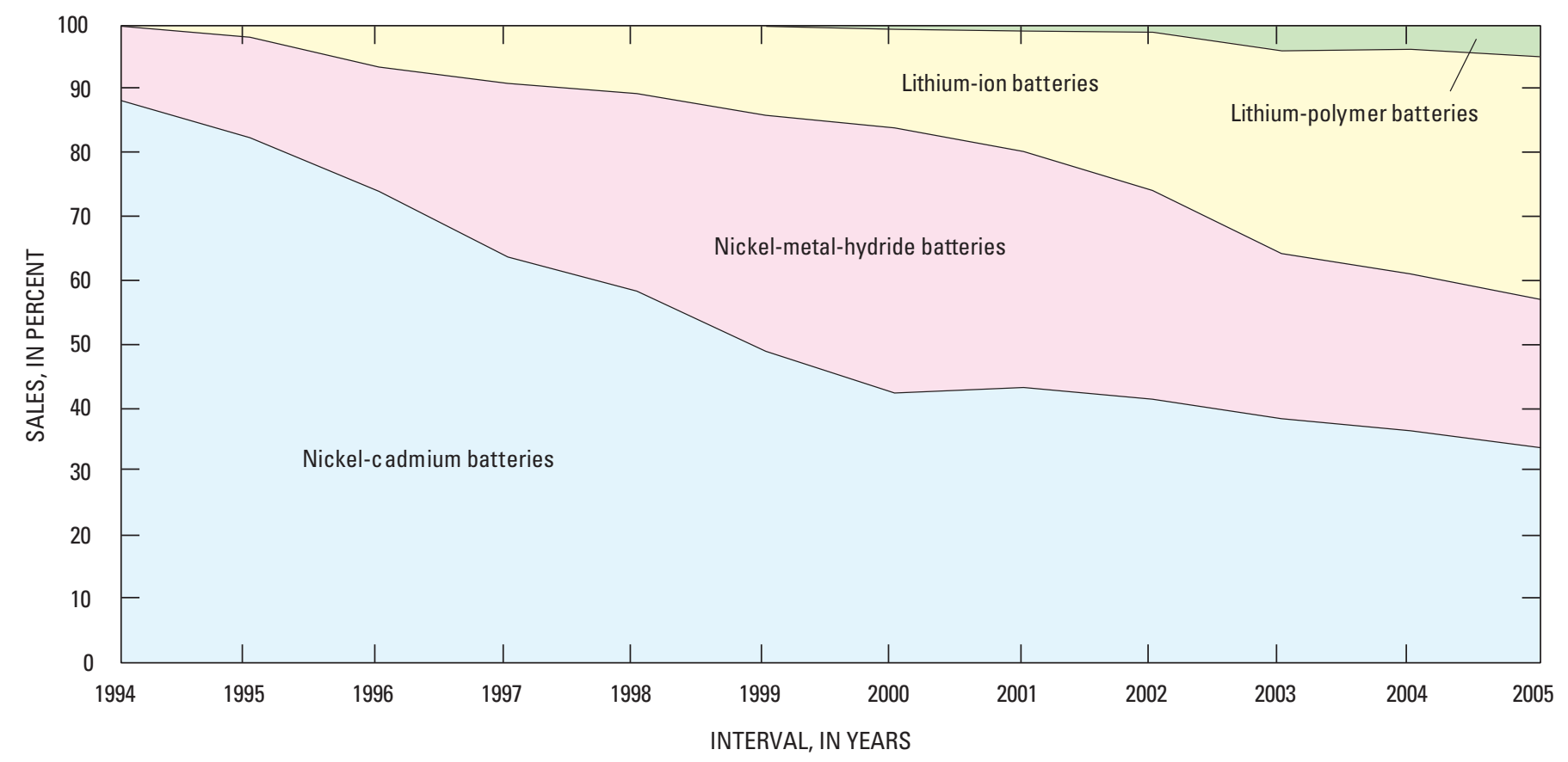

Figure 1. Graph showing percentage of global rechargeable battery sales for the principle battery types from 1994 through 2005. (Data from Pillot, 2005b, p. 19.) 
products and are regulating cadmium battery disposal (Klimasauskas and others, 2006). The U.S. Congress passed the Mercury Containing and Rechargeable Battery Act (referred to as the Battery Act) in 1996 to facilitate the recycling of $\mathrm{NiCd}$ and other rechargeable batteries by standardizing the collection, disposal, and labeling requirements previously enforced by State agencies (U.S. Environmental Protection Agency, 2002a). The battery industry is expected to be further affected by European Union directives issued in 2000 (2000/52/EC) and 2006 (2006/66/EC) that are designed to limit the use of batteries containing cadmium and mercury and to regulate the disposal and recycling of batteries.

The development and subsequent growth in the number and use of new products that require batteries have provided (and likely will continue to provide) opportunities for technological development within the battery sector. The use of cell phones in the United States, which grew to about 180 million units in 2004 from 340,000 units in 1985, is just one example where the growth of an industry has led to technological improvements in batteries designed to supply that end use (Most, 2003; Charny, 2005). Similarly, statistics reported by the U.S. International Trade Commission (ITC) show that significant expansion has transpired in the number of U.S. imports of portable computers $(1,200$ percent growth from 1996 to 2005), digital cameras (5,600 percent growth from 1996 to 2005), and other electronic games, toys, and music devices (data not reported separately). In the automotive sector, the development of advanced battery technology is expanding and is supported by industry and the U.S. Government. The Advanced Energy Initiative, announced in 2006 by President Bush, proposed to provide $\$ 31$ million toward advanced battery research (National Economic Council, 2006). Studies suggest that U.S. sales of hybrid vehicles powered by rechargeable $\mathrm{NiMH}$ and Li-ion batteries are likely to achieve 550,000 units by 2010, which is up from the 2005 level of about 190,000 units (U.S. Department of Energy, 2006). Consumer acceptance, cost considerations, energy requirements, supply issues, and size considerations of such products often determine which batteries will best meet the needs of such new applications. Technological changes by product manufacturers can lead to battery substitution from one type to another. Battery substitutions result in material use changes associated with these batteries; therefore, understanding the material requirements of available options is essential in order to assess present and future changes in material use, environmental consequences, and source of supply.

Environmental regulation and product end-use research and development have led to changes in battery composition, efficiency, and size. To date, however, no single battery technology has the cost, power, and efficiency requirements to meet the needs of the consumer for all applications. Consequently, battery manufacturers develop batteries that fit the requirements of a broad spectrum of products, thereby maximizing the power and efficiency profiles of the batteries to fit the requirements of those products. Technological advances further change the materials used in consumer batteries. As a result, batteries with a broad range of chemistries, shapes, and sizes are produced. Industry competition, rapid technological change, and the wide variety of batteries available all create challenges to gathering data about batteries used in the United States.

Because U.S. production of rechargeable batteries is limited to small-scale, high-profit-margin niche markets, such as medical, military, or space applications, most of the rechargeable batteries used in applications considered in this analysis are imported, primarily from China, Japan, and the Republic of Korea (Brodd, 2005). Comprehensive information on U.S. battery consumption, composition, recycling, and trade by end-use application often is not compiled or not made available to the public. The ITC reports data on the number of individual batteries imported into and exported from the United States annually and separately reports data on the number of manufactured products that use batteries. The ITC does not report the material content of these batteries. Battery recycling data have been reported since 1994 by the Rechargeable Battery Recycling Corporation (RBRC), but RBRC data are reported in terms of pounds of batteries recycled, and statistics on specific batteries collected and their material content are not reported over the range of years studied in this report. Although the RBRC is the largest U.S. rechargeable battery recovery organization, some municipalities, armed services, and government agencies also have conducted battery collection programs; and some larger battery manufacturers collect batteries and send them either to the International Metals Reclamation Company (INMETCO), the principal U.S. battery recycler, or to Asian or European recyclers (Boehme and Panero, 2003, p. 41).

Because comprehensive data on rechargeable battery use by type are not uniformly available, selected case studies were performed to provide the reader with several sets of data pertaining to material consumption issues related to the rechargeable battery industry. Each case study of selected battery end uses provides complementary assessments of the rechargeable battery industry. A more comprehensive picture of the industry can be developed by looking at a composite of these case studies.

\section{Study Methodology}

To gain a more complete understanding of the amount of material derived from mineral commodities that is used in the United States over time, it is useful to assess the amount of the material used both in its raw forms (ore, concentrate, or refined metal) and in manufactured products. The USGS reports annual production and consumption statistics for many mineral commodities in such annual publications as the Mineral Commodity Summaries and the Minerals Yearbook. The USGS does not, however, include in its annual assessments materials contained in manufactured products that are imported into or exported from the United States. Collection 
or estimation of these data is often impractical because of the number and variety of products involved and the amount of time required to collect and publish the data. Estimating the amount of a specific mineral commodity used in a product is difficult if that product comes in a variety of sizes and is produced using a variety of chemistries (as in the case of rechargeable batteries). Estimates can be made, however, if the industry uses a high percentage or large tonnage of the targeted mineral constituent in the end-use product, the product has a well-defined market structure, and data useful for estimating material usage of that mineral commodity are available.

Most of the rechargeable batteries used for consumer electronics and hybrid vehicles in the United States are imported, so a thorough study of the rechargeable battery sector requires data on the quantity of batteries, by type, which are imported and exported by the United States. The author selected data collected by the U.S. Bureau of the Census and reported by the ITC (U.S. International Trade Commission, 2006); these data are based on Harmonized Tariff Schedule of the United States (HTS) product classifications. The reported trade data are for batteries of different chemistries and are expressed in terms of the number of batteries or the number of products that contain batteries. The author used annual import and export data for 8 types of nonrechargeable (primary) batteries as indicated by the HTS code and 15 types of rechargeable (storage) batteries, as well as trade data for selected manufactured products that typically contain a battery as part of the prepackaged product. Products considered in this report include battery-powered automobiles and other vehicles, camcorders, cameras, cell phones, clocks and watches of different types, portable computers, power tools, and other small consumer devices.

Because ITC data are most often expressed in terms of the quantity of batteries, an estimate for the average amount of cadmium, cobalt, lithium, or nickel contained within each HTS battery classification or product code (which depends on the end use) was developed. Generalized material content specifications for each major battery chemistry or end-use application were developed from data reported in published material safety data sheets by selected manufacturers that produce the specified battery. Representative mineral content values were assigned by averaging the generalized material content data reported by these manufacturers. Based on the reported description for each HTS classification, a specific battery or group of batteries was selected to depict the "representative" battery for that classification. Cadmium, cobalt, lithium, and nickel content were estimated for each HTS classification on the basis of average weight of all batteries included in that classification as reported by the manufacturers and estimates of the typical material content for that battery type (Vangheluwe and others, 2005, p. 11). The HTS classifications for each battery chemistry and end-use application used in this study are included in the appendix. In cases where an HTS classification was thought to contain multiple battery chemistries or shapes, a determination was made as to what percentage of the classifica- tion was attributable to each battery chemistry or shape based on the reported worldwide distribution of batteries by application (Pillot, 2004, p. 29-31; 2005b, p. 14). Annual worldwide rechargeable battery sales data were used as an approximation for the types of batteries included in each of the major U.S. end-use applications (Pillot, 2004, p. 29-31).

Details on the estimation methods and the estimates of the average amount of cadmium, cobalt, lithium, and nickel contained in representative battery chemistries by end-use application for this report are summarized in the appendix. Not all battery constituents were assessed for this study; only the content of cadmium, cobalt, lithium, or nickel as metals or selected compounds was considered. Of the principal battery chemistries, $\mathrm{NiCd}$ batteries of a type used in selected end-use applications were evaluated for cadmium, cobalt, and nickel content; NiMH batteries were evaluated for their cobalt and nickel content; and primary lithium and Li-ion batteries types were evaluated for their cobalt and lithium content.

Although a variety of battery chemistries exist and other battery chemistries are being developed, only a select number of battery chemistries was analyzed for their cadmium, cobalt, lithium, and nickel content in this study. It should be noted that there is no lithium metal in the Li-ion batteries analyzed in this study; lithium occurs primarily in the form of lithium cobalt oxide $\left(\mathrm{LiCoO}_{2}\right)$ or lithium hexafluorophosphate $\left(\mathrm{LiPF}_{6}\right)$ compounds. Cobalt and nickel most commonly occur as cobalt hydroxide $\left(\mathrm{Co}(\mathrm{OH})_{2}\right)$ or nickel hydroxide $\left(\mathrm{Ni}(\mathrm{OH})_{2}\right)$ in positive electrodes of NiCd or NiMH batteries or as material components mixed with other metals contained in negative electrodes of NiMH batteries. Cadmium occurs as cadmium hydroxide $\left(\mathrm{Cd}(\mathrm{OH})_{2}\right)$ in positive electrodes of $\mathrm{NiCd}$ batteries.

\section{Case Study 1-Cell Phones}

The goals of the cell phone case study are as follows: illustrate the material changes that have taken place in the cell phone battery industry since 1995, estimate the growth in U.S. consumption of batteries used to power cell phones during the past 10 years, and discuss the effects of that growth on disposal alternatives (household storage, incinerating, landfilling, or recycling). Estimates were developed for the amount of material contained in cell phone batteries in the United States, the amount available for disposal at municipal solid waste (MSW) facilities, and the amount that was recycled.

The types of batteries used in cell phones worldwide have changed significantly since the early 1990s, when $\mathrm{NiCd}$ batteries dominated the world market. In 1996, the first year analyzed in this study, NiMH batteries represented an estimated 40 percent of the cell phone market, NiCd batteries represented an estimated 37 percent, and Li-ion batteries represented an estimated 23 percent (Pillot, 2005b, p. 19). Since 1996, the use of NiCd batteries in the world market has decreased while Li-ion battery use has significantly increased, first at the expense of $\mathrm{NiCd}$ batteries and then at the expense 
of NiMH batteries. Estimates suggest that, by $2005, \mathrm{NiCd}$ batteries had been completely replaced by Li-ion batteries for use in cell phones and that the NiMH battery market share had decreased to about 4 percent (Pillot, 2005b, p. 19). Since 2004, the Li-ion battery market share has fallen in favor of lithiumpolymer batteries, which represented about 17 percent of cell phone batteries in use in 2005 (Pillot, 2005b, p. 19).

Figure 2 summarizes estimated U.S. cell phone battery use and disposal data for the period from 1996 through 2005. U.S. cell phone subscription data were derived from Most (2003) and Charny (2005). Estimates of the number of imported batteries (by type) were derived from ITC data (U.S. International Trade Commission, 2006) that are based on the number of cell phones imported into and exported from the United States annually; because data on the number of individual batteries traded annually could not be differentiated by chemical type, they were excluded from this assessment. Esti- mates of the number of batteries available for disposal during the 10-year period were developed based on an average cell phone life of 2 years (Environmental Literacy Council, 2004; Ramamoorthy, 2006), the assumption that cell phones may be available for recycling or disposal at the time of service contract termination, and that the average cell phone requires only one rechargeable battery during its short life. For this analysis, it was assumed that 20 percent of batteries used in cell phones entering service in any given year would be retired in that year; 70 percent of these batteries would be retired in the second year, and the remaining 10 percent would be retired in the third year. Data suggest that about 90 percent of all cell phone batteries that are considered obsolete are either placed in temporary household storage or are discarded as MSW, and about 10 percent are recycled, according to estimates derived from data reported by the Rechargeable Battery Recycling Corporation (2005).

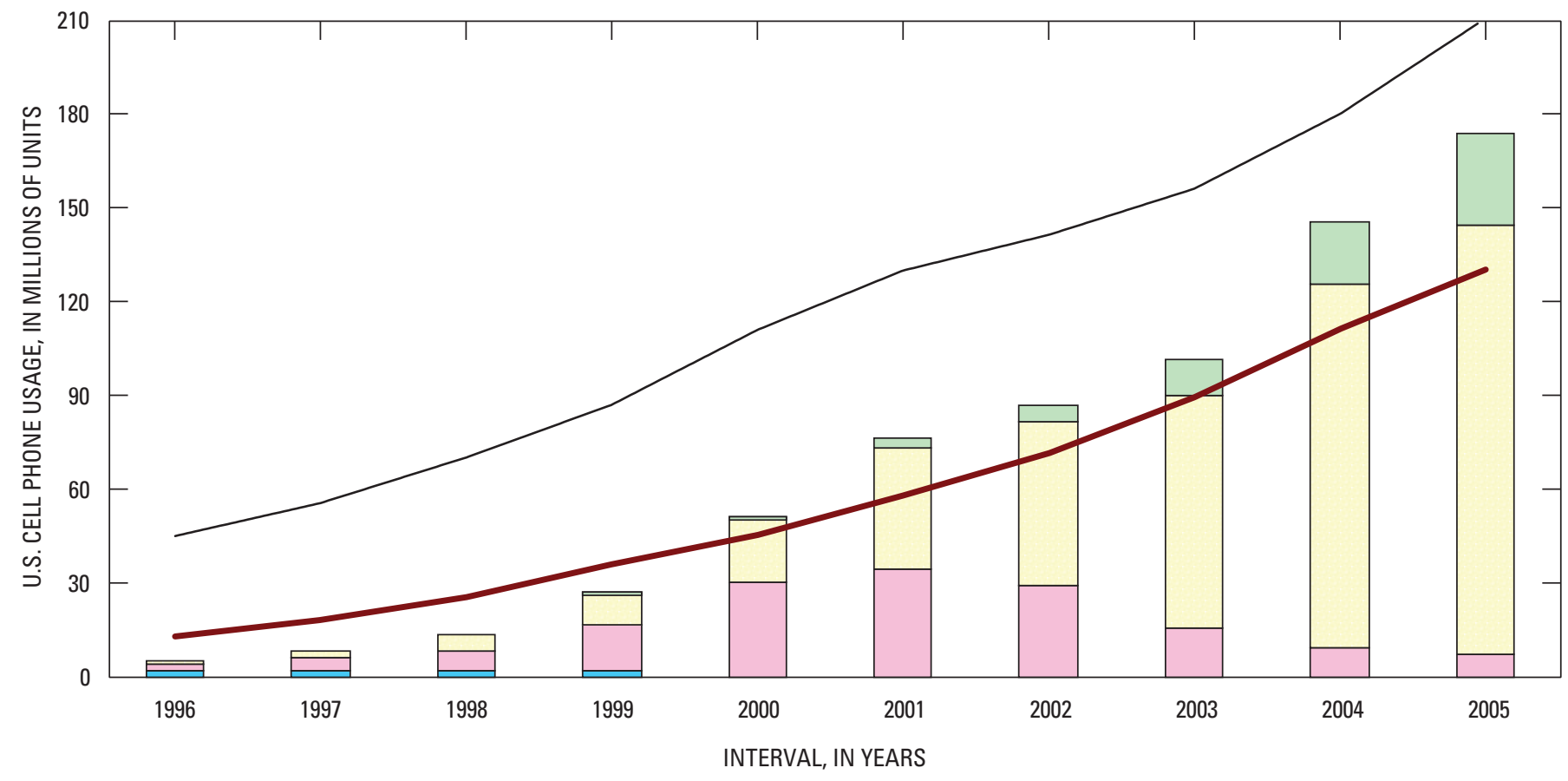

EXPLANATION

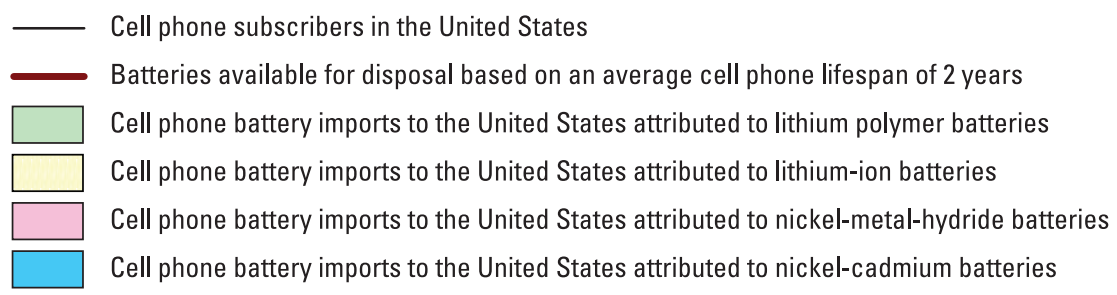

Figure 2. Graph showing U.S. cell phone subscription and import data compared with estimates for the number of cell phones available for disposal at the end of life. U.S. cell phone battery production data are not available but are to be assumed negligible when compared to the number of imported batteries. Subscriber data from Most (2003) and Charny (2005); import data from U.S. International Trade Commission (2006). Estimates for cell phone end-of-life data are based on an assumed contract life of 2 years (Fishbein, 2002), the assumption that each cell phone requires only 1 battery during its life, and the assumption that cell phones are available for disposal at the time of contract termination. 
The results of this study suggest that about 12 million cell phone batteries were available for disposal in 1996, which increased to about 130 million batteries in 2005. This increase is consistent with an estimate of 130 million cell phones anticipated to be retired by 2005, as reported by the U.S. Environmental Protection Agency (2005).

For this study, an assumption was made that the worldwide cell-phone-battery chemistry distribution, as reported by Pillot (2005b), is equivalent to the United States cell-phonebattery chemistry distribution. The material requirements reported in the appendix for the selected battery chemistries were used to develop estimates for the amount of cadmium, cobalt, lithium, and nickel contained in these batteries. The relative proportions of these materials in cell phone batteries are highly dependent on battery technology. Environmental regulations, changing cell phone technologies, and shifting consumer preferences during the 10-year study period led to substitution for $\mathrm{NiCd}$ batteries in cell phones, first by $\mathrm{NiMH}$ batteries, and then by Li-ion batteries. By 2005, lithium-polymer batteries began to erode the market share of the Li-ion batteries in cell phones. The estimates for battery distribution on an annual basis are necessary because of the rapid changes taking place in the types of batteries that were used in cell phones during the study period.

Technological innovation not only stimulated changes in cell phone battery technology, but also led to a noticeable reduction in cell phone size and weight because lithiumbased batteries are lighter than $\mathrm{NiCd}$ batteries and electronic circuitry refinements lead to increased miniaturization. The Environmental Literacy Council (2004) reported that the weight of a typical cell phone in the early 1990s was about 11 ounces and in 2000 was 7.7 ounces. In 2006, a typical cell phone weighed about 4.1 ounces (Nokia Corporation, 2006). The newest and most widely used lithium-based battery chemistries (Li-ion and lithium-polymer) weigh much less than older NiMH and NiCd batteries.

The study results suggest that about 4,700 metric tons ( $t$ ) of cobalt, 3,100 t of nickel, $580 \mathrm{t}$ of lithium, and $91 \mathrm{t}$ of cadmium were contained in cell phones that were estimated to be available for disposal from 1996 to 2005 in the United States. Estimates based on recycling data provided by the Rechargeable Battery Recycling Corporation (2005) suggest that about $410 \mathrm{t}$ of cobalt, $170 \mathrm{t}$ of nickel, and less than $10 \mathrm{t}$ each of cadmium and lithium contained in cell phone batteries may have been recovered from batteries recycled between 1999 and 2005. Thus, it is likely that about 4,300 t of cobalt, 2,900 t of nickel, $570 \mathrm{t}$ of lithium, and $83 \mathrm{t}$ of cadmium were contained in cell phone batteries discarded during the same period. Discarded material includes batteries retained in household storage for a time before entering the MSW landfills. Most of the cadmium, which is attributable to NiCd batteries, was discarded prior to 2001; most of the lithium was discarded after 2001. A significant quantity of nickel is contained in $\mathrm{NiCd}$ and NiMH batteries which were discarded during the entire 10-year period. A small amount of the discarded cell phone batteries was likely incinerated at MSW facilities.
The United States used about 28 percent of the 734 million cell phones that were sold worldwide in 2005 (Charny, 2005; Gartner, Inc., 2005). Growth in cell phone sales is taking place most rapidly in China and India; by 2008, it is estimated that these two countries may possibly account for about 45 percent of world cell phone use (Pillot, 2004, p. 26). By 2010, cell phone use in the United States may require about 250 million batteries, mostly of the $\mathrm{Li}$-ion and lithium-polymer type. If current trends in battery use continue, the tonnage of cadmium from cell phone batteries that may potentially enter landfills in 2010 will be very small, the amount of lithium and nickel that may potentially enter landfills will likely be similar to what was entered in 2005, and the amount of cobalt destined for landfills or household storage is likely to increase. These estimates assume that the recycling rate for cell phone batteries will increase at a rate similar to that forecasted for total battery recycling in the United States; the estimates do not account for an increased rate of substitution of cobalt by nickel and other metals. It is assumed that State regulations will continue to govern the types of batteries that will be allowed in MSW landfills in the States.

\section{Case Study 2-Cameras and Camcorders}

The focus of the camera and camcorder (video recording camera) case study is to show how the growth in the use of batteries that power these popular business and consumer products during the past 10 years in the United States has changed and to discuss the effects of this change on materials use and disposal. Estimates were developed for the amount of cadmium, cobalt, lithium, and nickel contained in camera and camcorder batteries that are used in the United States for each of the principal battery chemistries associated with these products, as summarized in the study methodology section and shown in the appendix.

The quantity and composition of materials used in nonrechargeable (primary) and rechargeable camera batteries and in analog and digital camcorder batteries have changed during the past 10 years because of technological developments associated with the products. Imports of still-image cameras (digital and film-based types) into the United States have grown to about 38 million in 2005 from about 680,000 in 1996 (U.S. International Trade Commission, 2006) because more cameras are manufactured outside the United States. Imports of video cameras and camcorders (both digital and analog types) into the United States also have increased, but at a slower rate- to about 5.9 million units in 2005 from about 3.7 million units in 1996. Figure 3 shows the quantity of U.S. net imports (imports minus exports) of cameras (fig. $3 A$ ) and camcorders (fig. $3 B$ ) for the period from 1996 through 2005. In 1996, about 90 percent of cameras used various types of primary (nonrechargeable) batteries, and about 10 percent used rechargeable $\mathrm{NiCd}$ batteries; by 2005, however, worldwide sales data suggest that 


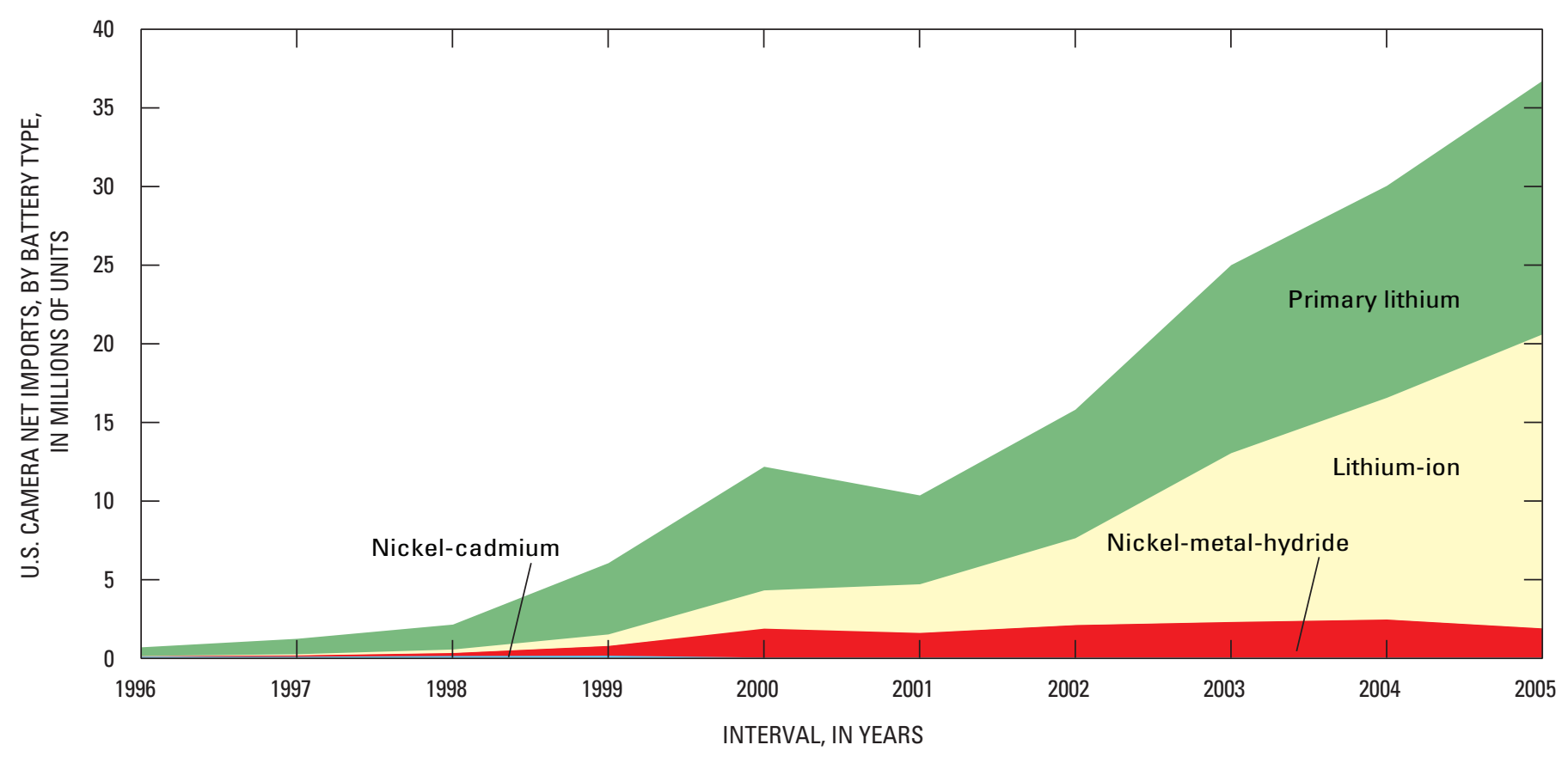

$A$

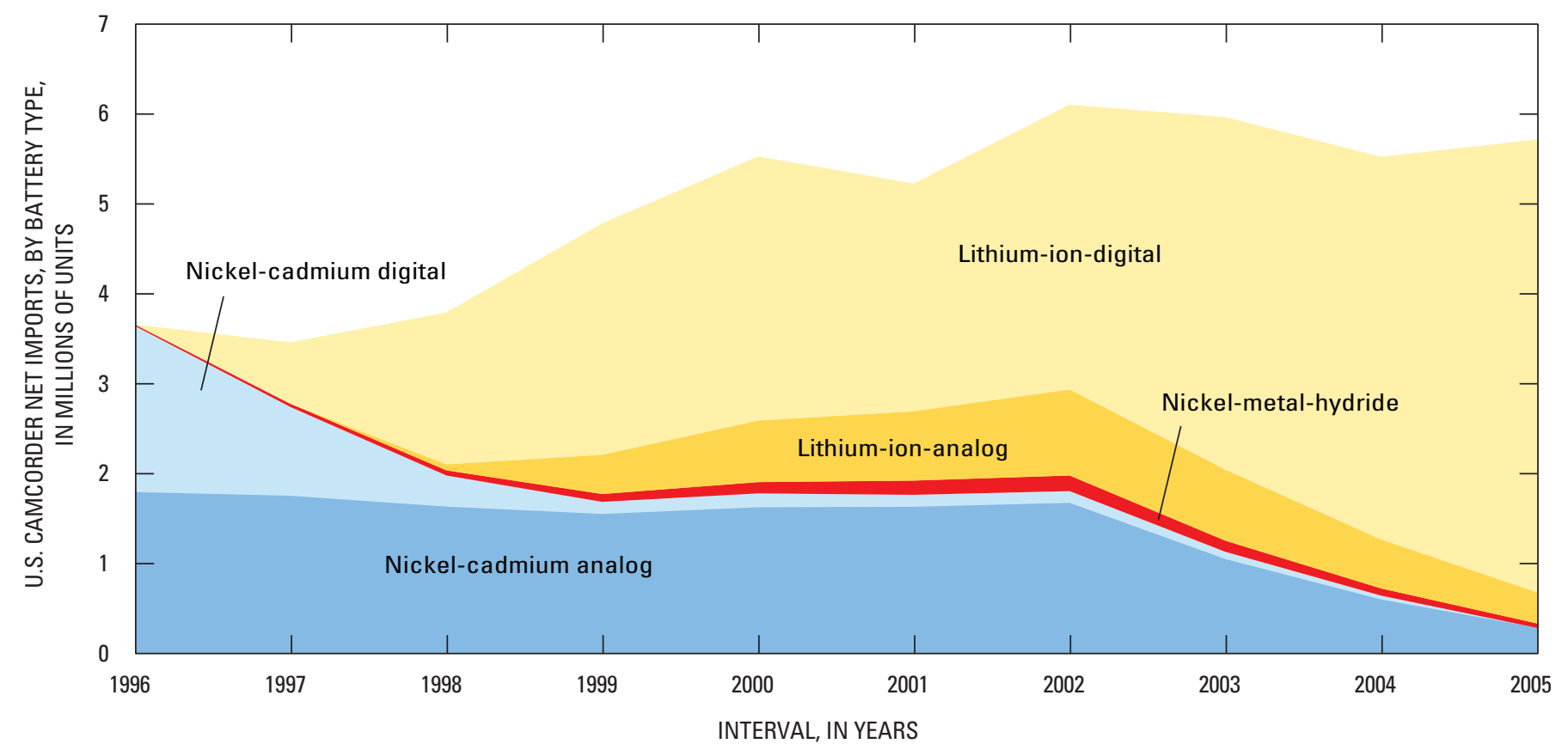

$B$

Figure 3. Graphs showing estimated U.S. net imports of $A$, cameras, and $B$, camcorders by battery type, in millions of units. Estimates were developed based on trade data from U.S. International Trade Commission (2006), net import data (imported products minus exported products) for each year, and percentage allocations by product type for each given year. World estimates for the camera and camcorder markets (Pillot, 2005a, p. 7) were assumed to apply to the United States. 
about 51 percent of camera batteries were Li-ion rechargeable batteries, 44 percent were primary batteries, and about 5 percent were NiMH rechargeable batteries (Pillot, 2004, p. 27). In 1996, about one-half of all U.S. camcorders were analog (8-millimeter) types; by 2005 , about 88 percent of all camcorders imported into the United States were digital types (U.S. International Trade Commission, 2006). Modern cameras and camcorders have become much more compact than those produced in the 1990s, primarily because of circuitry miniaturization; additionally, batteries contained in newer products have become more energy efficient, although most batteries used in these applications are similar in size to those used in 1996.

Significant material consumption patterns have changed within the camera sector as a result of cheaper prices, shifts in consumer preferences, and technological improvements. The changes are based on the assumption that observed variations in the quantity of selected U.S. imported products over time indicate trends. The increase in the use of camera batteries containing lithium (fig. $3 \mathrm{~A}$ ) represents the most significant change for the camera sector during the 10 -year study period. The estimate for the aggregated total lithium content of batteries contained in digital and film-based cameras sold in the United States has increased to more than $19 \mathrm{t}$ of lithium in 2005 from 100 kilograms of lithium in 1996. The NiCd batteries used in this application were phased out by 2000 . The total cobalt content of camera batteries used in the United States increased to almost $50 \mathrm{t}$ in 2005 from a negligible amount in 1996. The total nickel content of batteries used in this sector increased slightly to about $10 \mathrm{t}$ in 2005 (attributed primarily to NiMH batteries) from about $2 \mathrm{t}$ in 1996 (attributed to both $\mathrm{NiCd}$ and NiMH battery chemistries).

Although figure 3 shows a more modest growth pattern overall for the U.S. camcorder sector, the pattern of change in battery chemistry used during the 1996-2005 period is quite significant. Within this modest growth, some rather dramatic changes can be seen. Figure $3 A$ shows that growth within the camera battery sector happened mainly with primary lithium and rechargeable Li-ion batteries. Figure $3 B$ suggests that most of the growth in imports within the camcorder sector occurred during a transition from camcorders with NiCd batteries to camcorders with lithium-based batteries. In 1996, the number of camcorders using rechargeable Li-ion batteries was negligible; by 2005 , about 50 percent of analog camcorders and almost 100 percent of digital camcorders used Li-ion batteries (Pillot, 2005a, p. 7). NiCd battery use correspondingly decreased during the period to about 5 percent of camcorders (mostly analog) in 2005 from approximately 100 percent of all camcorders because of changes in consumer preference, battery availability, and technological factors. Figure $3 B$ shows the following three distinct periods of change for camcorder battery consumption:

1. From 1996 to 1998 - Characterized by a rapid decrease in NiCd battery imports for digital camcorders and a corresponding increase in Li-ion battery imports for this application.
2. From 1998 to 2002 - Characterized by an increase in Liion battery imports in analog and digital camcorders.

3. From 2002 to 2005 - Characterized by a decrease in imports of analog camcorders coupled with a decrease in imports of all principle battery chemistries except Li-ion batteries.

Since 1996, some States have placed limitations on the use of consumer batteries containing mercury, enacted guidelines for battery disposal, and encouraged increased recycling for all battery chemistries. During this same period, more efficient and powerful battery technologies have been developed that have increased the use of rechargeable batteries in a large number of end-use applications. In general, the material content of electronic consumer-product batteries used and disposed of in the United States has changed significantly in the past 10 years. Figure 4 illustrates some of the changes that have taken place since 1996 for camera and camcorder batteries. In the case of cameras and camcorders, the amount of cadmium contained in camera and camcorder batteries has decreased to about $7 \mathrm{t}$ in 2005 from about $83 \mathrm{t}$ in 1996. The amount of nickel contained in camera and camcorder batteries has similarly decreased to about $22 \mathrm{t}$ in 2005 from about $130 \mathrm{t}$ in 1996, primarily as a result of decreasing use of $\mathrm{NiCd}$ batteries within the sector. With the increase in use of lithiumbased batteries in the sector, the amount of lithium contained in camera and camcorder batteries has increased to about $26 \mathrm{t}$ in 2005 from about $82 \mathrm{t}$ in 1996, and the amount of contained cobalt has increased to $96 \mathrm{t}$ in 2005 from about $5 \mathrm{t}$ in 1996.

Recycling of used batteries in this sector has also increased. The net effect is that consumer preferences, government regulations, and technological advancements have combined to effectively reduce the amount of cadmium and nickel from batteries disposed of in MSW landfills because of an increase in the use of Li-ion batteries in end-use applications, such as cameras and camcorders.

\section{Case Study 3-Portable Computers}

As the price of the average portable (laptop) computer has decreased to the average price of a desktop computer 5 years ago, and as wireless Internet connections have become more available, the number of portable computers in use in the United States has grown. Net imports of portable computers into the United States have grown to about 20.6 million in 2005 from about 1.4 million in 1996 (U.S. International Trade Commission, 2006). In 2005, for the first time in U.S. history, portable computers outsold desktop computers and accounted for 51 percent of all U.S. personal computer sales (Kanellos, 2006). The focus of this case study is to show how technological advances in computers and the batteries used to power them led to the growth in portable computer use during the past 10 years, to discuss the changes in battery chemistry used in these products and the changing material 


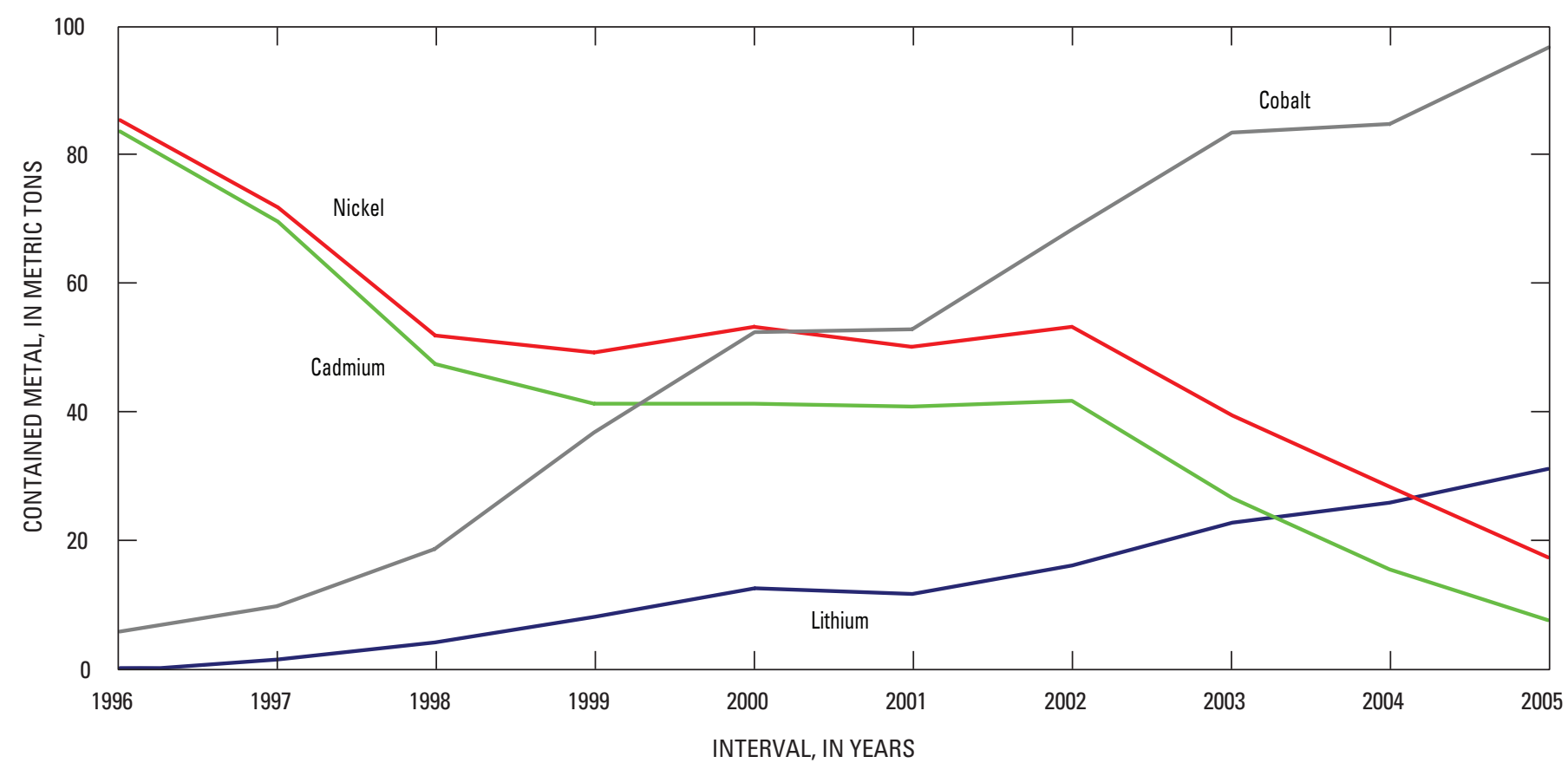

Figure 4. Graph showing estimated amounts of cadmium, cobalt, lithium, and nickel contained in rechargeable camera and camcorder batteries used in the United States from 1996 through 2005. Estimates were developed based on trade data from the U.S. International Trade Commission (2006), net import data (imported batteries minus exported batteries) for each year from the U.S. International Trade Commission (2006), assumed average metal content of batteries, and percentage allocations by battery chemistry for each given year. The worldwide rechargeable battery distribution by chemical type as reported by Pillot (2004, p. 27-31) is assumed to be equivalent to the United States rechargeable battery market distribution for cameras and camcorders.

needs of these batteries, and to discuss the ramifications of these changing growth patterns on material consumption and disposal. Estimates were developed for the amount of cobalt, lithium, and nickel contained in the Li-ion and NiMH batteries used in these computers. The estimates are based on ITC trade statistics and the average material requirements for specified battery classifications as determined by averaging the battery specifications reported by selected manufacturers.

Data for Li-ion and NiMH batteries used in portable computers show different trends. The shaded areas in figure 5 show that the use of Li-ion batteries in portable computers increased at a much faster rate than the use of NiMH batteries, primarily because of technological improvements in the Liion batteries that resulted in a lower unit price and increased energy efficiency. In 1996, NiMH batteries represented 55 percent of all net battery imports used in U.S. portable computers, as reported by the ITC; by 2005, the market share of NiMH batteries used in portable computers had dropped to about 8 percent (Pillot, 2005a, p. 6). Conversely, Li-ion batteries represented about 92 percent of the market share in 2005 and about 45 percent in 1996 (U.S. International Trade Commission, 2006).

Li-ion batteries have grown in popularity as a function of both price and efficiency relative to other principle battery chemistries. The Li-ion batteries are priced higher than other comparable battery types, but the average price of a Li-ion battery dropped from about $\$ 5$ per cell in 2000 to about $\$ 2.50$ per cell in 2005, compared with a 2005 price estimate of about $\$ 0.75$ per cell for $\mathrm{NiCd}$ and $\$ 1.00$ per cell for NiMH batteries (Pillot, 2005b, p. 18; Pillot, 2006b, p. 17). The Li-ion battery, however, has a higher energy density (greater energy storage capacity per weight) and is lighter (less dense) than $\mathrm{NiCd}$ or NiMH products, which makes it preferable as a power source for portable items such as cell phones, camcorders, and portable computers. Technological advances have improved the performance characteristics of Li-ion batteries. In 1992, when they were first introduced, the Li-ion battery had only a 10 percent higher energy density than a comparable NiMH battery; by 2005 , the Li-ion battery had an average energy density about 80 percent greater than the NiMH battery (Pillot, 2005 b, p. 16). As the price difference between these two types of batteries decreases, consumers and manufacturers may be more willing to use batteries with the higher energy density and lower weight.

Estimates of the quantity of cobalt, lithium, and nickel contained in batteries consumed by the portable computer sector from 1996 to 2005 are illustrated on figure 5. Assumptions used in developing these estimates are reported in the appendix (table A-6). ITC trade data for the United States were used to estimate the amount of net imports by battery chemistry, and battery data reported by selected manufacturer's material safety data sheets were used to assign average composition values for each of the principal rechargeable battery chemistries. HTS classifications for each battery chemistry and end 


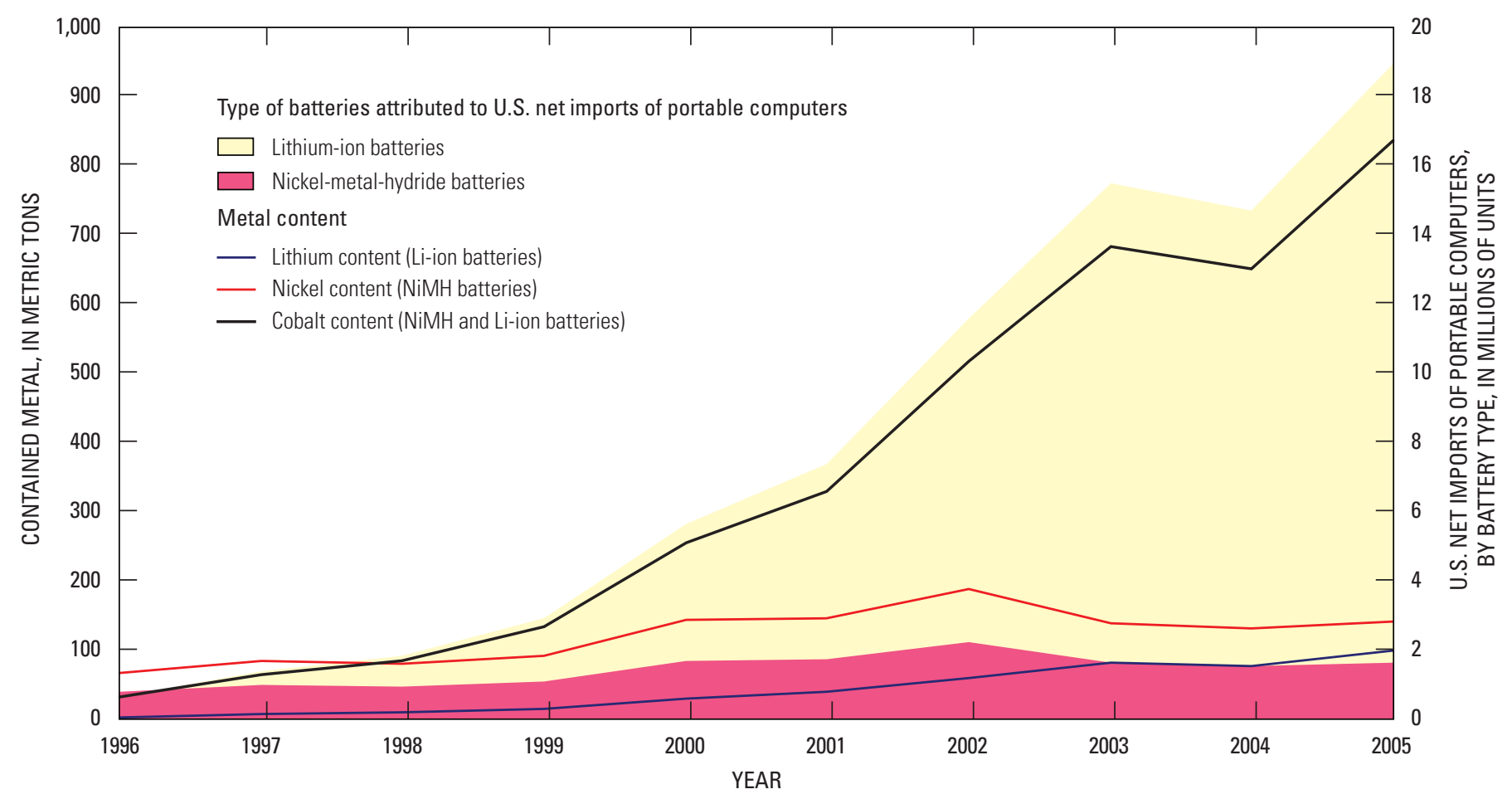

Figure 5. Graph showing estimated imports of portable computers by battery type and amounts of cobalt, lithium, and nickel contained in rechargeable portable computer batteries used in the United States from 1996 through 2005. Estimates are based on trade data from the U.S. International Trade Commission (2006), net import data (imported batteries minus exported batteries) for each year from the U.S. International Trade Commission (2006), assumed average metal contents of these batteries, and percentage allocations by battery chemistry for each given year. The worldwide personal computer rechargeable battery market distribution as reported by Pillot (2005a, p. 6) is assumed to be equivalent to the United States rechargeable battery market distribution for portable computers.

use analyzed in this study are listed in the appendix (table A-11).

The total amount of lithium contained in Li-ion batteries used by portable computers in the United States has increased to nearly $100 \mathrm{t}$ in 2005 from less than $4 \mathrm{t}$ in 1996 owing to the increased use of Li-ion batteries in portable computers. Total nickel content of NiMH batteries used in portable computers increased to about $190 \mathrm{t}$ of nickel by 2002 from about 67 $\mathrm{t}$ of nickel in 1996, then dropped to about $140 \mathrm{t}$ of nickel by 2005. Assuming that the predominant Li-ion battery chemistry is $\mathrm{LiCo}(\mathrm{OH})_{2}$, the total cobalt content of $\mathrm{Li}$-ion and $\mathrm{NiMH}$ batteries used in portable computers increased to about 840 $\mathrm{t}$ (about $8 \mathrm{t}$ in NiMH and $830 \mathrm{t}$ in Li-ion) in 2005 from 32 $\mathrm{t}(4 \mathrm{t}$ in NiMH and $28 \mathrm{t}$ in Li-ion) in 1996. The number of portable computers sold worldwide is projected to increase by 35 percent from 2005 to 2010, and estimates suggest that Li-ion batteries will hold a near 100 percent market share of rechargeable batteries used in portable computers in 2010 (Pillot, 2005a, p. 6), barring the commercial implementation of new technologies, such as fuel cells, which have different material requirements. Applying these figures to the most recent U.S. trade data suggests that in 2010 the U.S. portable computer sector may use more than $1,100 \mathrm{t}$ of cobalt and 130 $t$ of lithium for the manufacture of portable computer batteries. From 2005 through 2010, nickel consumption is expected to decrease as NiMH batteries are further replaced by Li-ion batteries in portable computers.

These estimates assume that there are no large changes in the overall chemical composition of rechargeable batteries from 2005 through 2010; it is expected, however, that continued technological improvement could result in small variations in battery composition and that some market penetration by lithium-polymer or fuel cells could take place by 2010 . Changing commodity prices could also influence substitution. Pillot (2005a, p. 14) suggests that fuel cell use in portable computer applications may well account for as much as 4 percent of the market by 2010; other researchers report that widespread use of fuel cells to power small consumer products is more likely to take place after 2010 .

Li-ion batteries used in selected models of portable computers have been recalled by various computer manufacturers since 2005 because of a possible fire hazard posed by the battery overheating. This study does not attempt to assess the effect of such recalls on future battery consumption, but it does assess the effect of these recalls on the amount of lithium that has entered recycling and disposal flows. Based on the data reported by the U.S. Consumer Product Safety Commission, approximately $235,000 \mathrm{Li}$-ion batteries were recalled in the United States in 2005, and about 4.3 million additional batteries were recalled in the United States as of November 
2006 (U.S. Consumer Product Safety Commission, 2007). If it is assumed that each of these recalled battery packs contained nine individual cells, and each cell contains an average of 4.9 grams $(\mathrm{g})$ of cobalt and $0.58 \mathrm{~g}$ of lithium per cell, then the cumulative amount of cobalt contained in the recalled batteries is estimated to be about $10 \mathrm{t}$ of cobalt and $1.2 \mathrm{t}$ of lithium in 2005 and about $190 \mathrm{t}$ of cobalt and $22 \mathrm{t}$ of lithium in 2006. However, because these recalls are voluntary, the amount of batteries actually returned by the consumer may be lower. While it is uncertain how much of this material will end up in U.S. landfills, Li-ion batteries are generally considered less toxic than $\mathrm{NiCd}$ batteries, and the environmental effect of these sudden recalls is expected to be minimal (Ames, 2006). Many of the computer manufacturers have contracts with the RBRC to recycle discarded batteries, so it is likely that most of those batteries that are returned to the manufacturers will be recycled; the recycled material is then returned to the manufacturers as feed material for new batteries. Metals recovered from battery recycling by INMETCO may be used in steelmaking. The RBRC reported a 6.4 percent increase in batteries recycled during the first 6 months of 2006 compared with the same time period in 2005; some of this increase could be attributable to Li-ion batteries that were recycled as a result of the recalls.

\section{Case Study 4-Hybrid Vehicles}

A study of rechargeable batteries would not be complete without considering the effect of the growth in the hybrid electric vehicle (HEV) industry on the rechargeable battery industry. HEVs combine the internal combustion engine of a conventional vehicle with the battery and electric motor of an electric vehicle. The first commercially produced HEV was introduced into the U.S. market in 1999; since that time, more U.S. and foreign automobile manufacturers have included HEVs in their U.S. automotive lineup, and demand for vehicles equipped with hybrid electric technology is increasing. Because this market sector for rechargeable batteries is changing rapidly, this case study evaluates not only 19962005 material use levels, as was done in the other case studies, but also assesses anticipated cobalt, lithium, and nickel use in this sector from 2005 to 2010. Material use estimates for this period were derived from U.S. HEV sales estimates reported by the U.S. Department of Transportation and the U.S. Department of Energy, Energy Information Administration, and from estimates of the percentage of vehicles that use various types of HEV batteries, as reported by Madani (2005).

Much research into improving automotive battery technology by the creation of low-cost but energy-efficient battery systems is ongoing. As of 2008, all commercially available HEVs are powered by NiMH battery systems and internal combustion engines. Li-ion battery systems, improved NiMH systems, and hydrogen-powered fuel cells are in development, but NiMH battery systems are expected to remain the predominant source of electric power for HEVs until at least 2010.

The two main hindrances to the establishment of a strong, growing HEV sector in the short term are the time required for battery development and the high price of HEV batteries. Research suggests that the period of battery development to commercial implementation is from 4.5 to 7 years (Madani, 2005, p. 15). Consequently, battery technologies undergoing initial research in 2005 are not likely to be placed in service before 2010. A number of research initiatives conducted jointly by automobile manufacturers and battery producers to develop commercially viable $\mathrm{Li}$-ion batteries for vehicles have been initiated since 2003. Batteries generated from these collaborative efforts, however, are unlikely to reach the market before 2008. Large-scale Li-ion battery production suitable for HEVs is therefore unlikely before 2010 .

Although the technology required to produce the small cells used in portable consumer electronics is transferable to the production of battery packs suitable for HEVs, the optimum energy storage characteristics of HEV batteries are different and make these batteries more costly. One firstgeneration HEV battery weighed about $50 \mathrm{~kg}$ and required 228 D-size NiMH cells. Another first-generation HEV battery used 240 to 250 D-size NiMH cells that weigh a combined $144 \mathrm{~kg}$ (Madani, 2005, p. 9). The higher cost of such battery packs requires automobile manufacturers to charge a premium for their HEVs over conventionally powered automobiles that use lead-acid batteries to power internal combustion engines.

Battery electrical energy requirements vary by battery chemistry and the intended battery use. The more popular HEVs use batteries primarily designed to provide rapid acceleration rather than as the primary source of motive power. One desirable attribute of this kind of battery is high specific energy [the amount of energy stored in watthours (Wh) per unit mass in kilograms (kg)] or energy density [energy stored in Wh per unit volume in liters (L)]. A main advantage of the Li-ion battery technology is its ability to provide a high energy density that ranges from 175 to $310 \mathrm{Wh} / \mathrm{L}$ (144 to $255 \mathrm{Wh} / \mathrm{kg}$ ). A conventional lead-acid battery designed to be the primary power source for a vehicle typically achieves only $89 \mathrm{Wh} / \mathrm{L}$ $(73 \mathrm{Wh} / \mathrm{kg}$ ) (Gaines and Cuenca, 2000, p. 6). The specific energy for a NiMH battery system used in HEVs is about 56 Wh/L (46 Wh/kg) (Panasonic EV Energy Co., Ltd., 2006).

The cost to provide the high level of specific energy necessary for an HEV battery is significant. In 2005, the cost of a typical NiMH battery was $\$ 0.50$ per watthour, while the cost of a Li-ion battery was about $\$ 2.20$ per watthour (Madani, 2005 , p. 18). At an average energy requirement of 1,300 watts (W), this translates to an average cost of about $\$ 650$ per NiMH battery and about $\$ 2,860$ per Li-ion battery. Battery costs are projected to drop to an estimated $\$ 0.28$ per watthour for a NiMH battery and $\$ 0.80$ per watthour for a Li-ion battery by 2010 (Madani, 2005, p. 19). If so, the typical cost of an 1,800 -W battery in 2010 would be about $\$ 500$ for a NiMH battery and about $\$ 1,400$ for a Li-ion battery. Improvements in battery technology could result in further cost reductions. 
Given the cost and technology constraints, what effect did the changing vehicle battery market have on the use of cobalt, lithium, and nickel in hybrid vehicle batteries for the period 1996 through 2005 and their projected use for 2006 through 2010? Vehicle production statistics reported by the U.S. Department of Transportation, vehicle sales projections reported by the U.S. Department of Energy, trade statistics reported by the ITC, HEV sales forecasts provided by Pillot, (2006a, p. 17), Paumanok Publications, Inc. (2006), and the National Renewable Energy Laboratory (Pesaran, 2006) were used to estimate the relative amount of these materials consumed in vehicle batteries through 2005 to provide estimates of selected material use based on projections of HEV vehicle sales for the period from 2005 through 2010.

Table 1 provides estimates of the amount of cobalt, nickel, and lithium contained in batteries from domestic and imported HEVs in the United States from 1996 to 2010. The estimates are based on the number of HEVs reported as sold or leased from 1996 to 2003 and projections of U.S. vehicle sales from both domestic and foreign manufacturers to 2010 (U.S. Department of Energy, 2006; U.S. Department of Transportation, 2006). These estimates assume one battery pack per vehicle sold during the period considered for this study and do not take into account defective or replacement batteries. HEVs were first introduced commercially to the U.S. market in 1999. Since that year, HEV vehicle imports to the United States gradually increased until 2004, when some U.S. automobile manufacturers added HEVs to their product lines. Available data suggest that the rate of HEV vehicle sales after 2004 will grow more rapidly, such that the quantity of HEVs sold in the United States may reach 550,000 units in 2010. Projections by Madani (2005), Paumanok Publications (2006), and The Freedonia Group Inc. (2006) suggest a higher level of future HEV sales than do estimates from the U.S. Department of Energy (2006) used in this analysis, because they include sales of replacement HEV batteries in their estimates. Projections, however, can be affected by changes in energy prices, technological breakthroughs, and other unanticipated factors.

Estimates for the amount of nickel contained in NiMH batteries used in HEV passenger vehicles and light trucks is expected to increase by a factor of 10 between 2003 and 2010, reaching about 7,300 $\mathrm{t}$, as demand for HEVs that use this type of battery increases. Estimates for the amount of cobalt used in HEV batteries are likely to increase gradually from 2003 to 2008 , at which time commercial production of Li-ion batteries for HEVs is expected to come online. If this takes place, then cobalt use in HEV batteries is projected to increase to about $210 \mathrm{t}$ in 2010 from about $7 \mathrm{t}$ in 2007, including both NiMH and Li-ion HEV batteries. Data suggest that in 2010, NiMH batteries would still be found in about 95 percent of HEVs, or more than 3 percent of the vehicles sold in the United States. The amount of lithium in HEV batteries is expected to remain at low levels until 2010, a function of low HEV battery production levels, the small percentage of HEVs that use Li-ion batteries, and the small amount of lithium contained within a Li-ion battery.

\section{Summary and Conclusions}

Consumer preferences, decreasing battery costs, environmental regulation, increasing fuel costs, new end-use markets, and technological advances have all played a role in the changing consumption and substitution patterns of rechargeable batteries, particularly in automotive and consumer electronic product applications. Table 2 summarizes cadmium, cobalt, lithium, and nickel consumption estimates for batteries used in selected consumer products assessed in this report for the period from 1996 through 2005. For each of the four mineral-based commodities evaluated, the amount of material used in selected end-use applications is given along with reference values of total annual U.S. apparent consumption for these metals as reported by the USGS. Although comparison of such data may be used to suggest gross trends in material consumption, direct comparison is not recommended because calculations of total U.S. apparent consumption do not include material contained in manufactured products imported to or exported from the United States, so total material consumption may be underestimated (Wilburn and Buckingham, 2006).

Total U.S. apparent consumption of cadmium appeared to decrease in a manner similar to that of the overall decline for the analyzed end-use sectors. U.S. apparent consumption of cobalt remained generally constant during the 10-year study period. In contrast, cobalt use attributed to rechargeable cell phone and portable computer batteries increased. In 2005, the cobalt content of cell phone batteries in use in the United States was estimated to be $1,400 \mathrm{t}$, or about 12 percent of the calculated 2005 U.S. apparent consumption value. Similarly, the estimated 2005 cobalt content of portable computer batteries in use in the United States was $840 \mathrm{t}$, or about 7 percent of the calculated 2005 U.S. apparent consumption value. U.S. apparent consumption of lithium decreased from 2001 through 2004 primarily as a result of decreased U.S. aluminum production (Ober, 2002). Lithium use in the United States that is attributable to the rechargeable battery sector, however, increased since 2002, primarily in such popular consumer products as cell phones and portable computers. The most noticeable trends in nickel use in rechargeable batteries relate to the decrease in the amount of nickel used in cell phone batteries as Li-ion batteries have increasingly replaced $\mathrm{NiMH}$ batteries in cell phones, and the increasing amount of nickel used in HEV batteries. As the number of hybrid vehicles in use increases, the use of nickel in NiMH batteries that power such vehicles also will increase, until such time as alternative technology supplants the use of NiMH in batteries.

U.S. cadmium use in consumer electronic batteries has generally declined (table 2 ) since cadmium was recognized as a possible human carcinogen in 1992. This finding resulted in the implementation of regulations affecting battery recycling and disposal and the introduction of technological advancements in other battery chemistries that are increasingly used as alternatives. For the period 1996 through 2000, camcorder batteries imported into the United States used more cadmium (up to $82 \mathrm{t}$ ) 


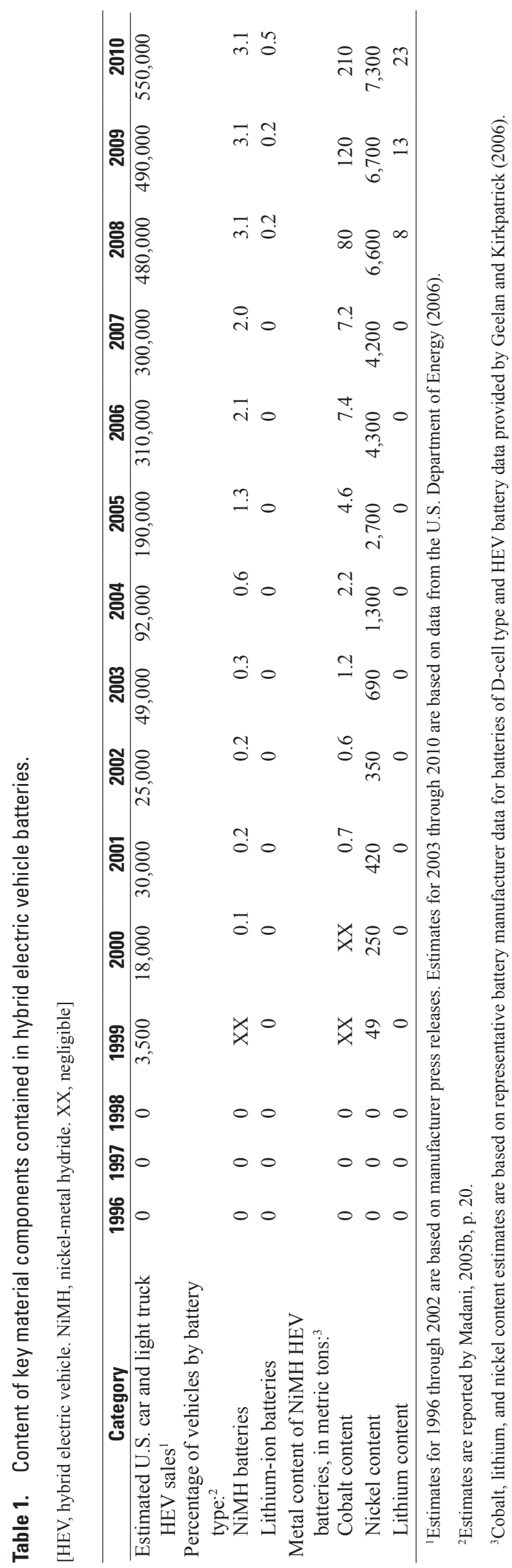


Table 2. Reported U.S. apparent consumption for selected metals and the content of these metals in batteries used in popular consumer products for the period 1996 through 2005.

[Units expressed as metric tons. XX, negligible]

\begin{tabular}{|c|c|c|c|c|c|c|c|c|c|c|}
\hline & 1996 & 1997 & 1998 & 1999 & 2000 & 2001 & 2002 & 2003 & 2004 & 2005 \\
\hline \multicolumn{11}{|c|}{ Cadmium } \\
\hline U.S. apparent consumption ${ }^{1}$ & 2,250 & 2,510 & 2,100 & 1,850 & 2,010 & 1,000 & 1,460 & 637 & 1,170 & 656 \\
\hline Camcorder batteries $^{3}$ & 82 & 68 & 45 & 38 & 41 & 40 & 41 & 26 & 15 & 6.9 \\
\hline Camera batteries $^{3}$ & 1.2 & 1.1 & 2 & 2.3 & 0 & 0 & 0 & 0 & 0 & 0 \\
\hline \multicolumn{11}{|c|}{ Cobalt } \\
\hline U.S. apparent consumption ${ }^{4}$ & 9,380 & 11,200 & 11,500 & 10,700 & 11,600 & 11,800 & 9,830 & 10,000 & 9,920 & 11,900 \\
\hline \multicolumn{11}{|l|}{ Cobalt content, by battery type: ${ }^{2}$} \\
\hline Camcorder batteries ${ }^{3}$ & 5.2 & 9 & 17 & 33 & 43 & 43 & 52 & 52 & 47 & 47 \\
\hline Portable computer batteries ${ }^{3}$ & 32 & 65 & 84 & 130 & 260 & 330 & 520 & 690 & 650 & 840 \\
\hline Total & 55 & 120 & 170 & 330 & 620 & 760 & 1,100 & 1,500 & 1,800 & 2,300 \\
\hline \multicolumn{11}{|c|}{ Lithium } \\
\hline U.S. apparent consumption ${ }^{6}$ & 2,700 & 2,800 & 2,800 & 2,800 & 2,800 & 1,400 & 1,100 & 1,400 & 1,900 & 2,500 \\
\hline \multicolumn{11}{|l|}{ Lithium content, by battery type: ${ }^{2}$} \\
\hline Camcorder batteries ${ }^{3}$ & 82 & 68 & 45 & 38 & 40 & 40 & 43 & 26 & 15 & 6.9 \\
\hline Camera batteries $^{3}$ & 0.1 & 0.3 & 0.5 & 1.7 & 4.1 & 3.9 & 6.5 & 12 & 15 & 19 \\
\hline Cell phone batteries ${ }^{3}$ & 1.8 & 4.9 & 8 & 18 & 34 & 45 & 62 & 92 & 140 & 170 \\
\hline Portable computer batteries ${ }^{3}$ & 3.3 & 7.1 & 10 & 15 & 29 & 38 & 60 & 81 & 77 & 99 \\
\hline Camera batteries $^{3}$ & 1.8 & 2.2 & 3.6 & 6.5 & 9.3 & 7.9 & 10 & 11 & 12 & 9.4 \\
\hline Cell phone batteries ${ }^{3}$ & 84 & 120 & 210 & 430 & 830 & 540 & 450 & 230 & 140 & 110 \\
\hline Hybrid vehicle batteries ${ }^{5}$ & $\mathrm{XX}$ & $\mathrm{XX}$ & $\mathrm{XX}$ & 49 & 250 & 420 & 350 & 690 & 1,300 & 2,700 \\
\hline Portable computer batteries ${ }^{3}$ & 67 & 84 & 79 & 92 & 140 & 150 & 190 & 140 & 130 & 140 \\
\hline Total & 280 & 310 & 370 & 640 & 1,300 & 1,200 & 1,100 & 1,100 & 1,600 & 3,000 \\
\hline
\end{tabular}

${ }^{1}$ Source data for 1996-2003, U.S. Geological Survey (2005); source data for 2004-05, Cooper and Kuck (2007). Apparent consumption is reported here for reference only, as it does not include materials contained in manufactured products imported to or exported from the United States.

${ }^{2}$ Sum of the metal contained in net imports of batteries applicable to each end use evaluated in this study. Values rounded to 2 significant digits and totaled to nearest whole number.

${ }^{3}$ Estimates derived from U.S. International Trade Commission (2006).

${ }^{4}$ Source data for 1996-2003, U.S. Geological Survey (2005); source data for 2004-05, Shedd (2007).

${ }^{5}$ Estimates derived from U.S. Department of Energy (2006), U.S. Department of Transportation (2006), U.S. International Trade Commission (2006).

${ }^{6}$ Source data for 1996-2005, Ober (1997-2007), Ober (2002), Ober (2003), Ober (2004), Ober (2005), Ober (2006), Ober (2007).

${ }^{7}$ Source data for 1996-2003, U.S. Geological Survey (2005); source data for 2004, Kuck (2005); source data for 2005, Kuck (2007). 
than any other application examined in this study. Cadmium use in camcorder batteries declined to about $7 \mathrm{t}$ in 2005 from $82 \mathrm{t}$ in 1996. NiCd rechargeable batteries have been replaced by $\mathrm{Li}$-ion and $\mathrm{NiMH}$ rechargeable batteries in cameras since about 2000 and in cell phones since about 2001. In contrast to the decline in $\mathrm{NiCd}$ battery usage, the number of spent $\mathrm{NiCd}$ batteries that end up in landfills has increased in the past 10 years. Study data suggest that about $91 \mathrm{t}$ of cadmium was contained in cell phone batteries available for recovery or disposal from 1996 through 2005, although much of this material was discarded prior to 2001. Efforts to recycle NiCd batteries have increased. The percentage of cadmium metal recovered from the reservoir of available NiCd batteries of all types was estimated by the USGS to range from 10 to 27 percent for the 1996 to 2007 period. The collection rate for large industrial NiCd batteries in the United States was reported to be approximately 80 percent, while the collection rate for small portable rechargeable batteries in the United States was reported to range from 5 to 21 percent (Hawkins and others, 2006).

During the period from 1996 through 2005, cobalt use in rechargeable batteries grew in all the end-use applications assessed in this study (table 2). Cell phones and portable computers consumed the greatest amount of cobalt in 1996, the former because of the large number of battery cells in circulation and the latter because of the larger cobalt content in computer battery packs. Estimates suggest that in 1996, cell phone batteries accounted for about 18 t of cobalt; by 2005 , the amount of cobalt contained in cell phone batteries had increased to about $1,400 \mathrm{t}$. The use of cobalt in portable computer batteries similarly increased to about $840 \mathrm{t}$ in 2005 from about $32 \mathrm{t}$ in 1996 because of increased use of Li-ion batteries in portable computers. Of the estimated 4,700 $\mathrm{t}$ of cobalt from cell phones available for recovery or disposal between 1996 and 2005, about $410 \mathrm{t}$ was recycled, and about 4,300 t was exported, stored, or disposed of in MSW landfills.

Lithium use in rechargeable batteries has grown with the increased use of Li-ion and lithium-polymer battery chemistries in consumer electronics. Although U.S. apparent consumption of lithium (excluding materials contained in manufactured imported products) decreased from 2000 through 2004 (table 2) primarily as a result of decreased U.S. aluminum production (Ober, 2002), increased U.S. consumption of lithium as a component of rechargeable batteries contained in consumer electronic products imported to the United States may have helped offset reduced U.S. consumption from other sectors. Cell phones and portable computers consumed the greatest amount of lithium in 2005, the former because of the large number of battery cells in circulation and the latter because of the larger lithium content in computer battery packs. In 1996, cell phone batteries accounted for $1.8 \mathrm{t}$ of lithium; by 2005, the amount of lithium contained in cell phone batteries had increased to 170 t. Similarly, portable computer batteries accounted for $3.3 \mathrm{t}$ of lithium in 1996 and $99 \mathrm{t}$ in 2005. Study data suggest that up to about $580 \mathrm{t}$ of lithium was contained in cell phone batteries available for recovery or disposal from 1996 through 2005. Changes in camcorder and camera technology from 1996 through 2005 had the net effect of reducing the lithium content per battery for these applications; because the number of cameras (primarily digital) used in the United States increased during this period, however, the total quantity of lithium contained in camera batteries used in the United States increased.

The overall pattern of U.S. nickel consumption for the electronic consumer products studied changed significantly during the period from 1996 through 2005. Nickel consumption derived from $\mathrm{NiCd}$ batteries that powered cell phones increased to $830 \mathrm{t}$ in 2000 from $84 \mathrm{t}$ in 1996, then decreased to $110 \mathrm{t}$ in 2005 (table 2) as lithium-based batteries increasingly substituted for $\mathrm{NiCd}$ batteries and then for $\mathrm{NiMH}$ batteries, and as cell phone batteries became smaller and used less nickel per cell. Nickel consumption in portable computer batteries gradually increased to $140 \mathrm{t}$ in 2005 from $67 \mathrm{t}$ in 1996; nickel consumption in camera batteries remained below $13 \mathrm{t}$ for the entire period; and nickel consumption in camcorder batteries decreased to $13 \mathrm{t}$ in 2005 from $130 \mathrm{t}$ in 1996. Technological and consumer preference changes are the primary reasons for these consumption pattern changes. Of the estimated 3,100 t of nickel in cell phones available for recovery or disposal between 1996 and 2005, about 170 t of nickel was recycled and about 2,900 t was exported, stored, or disposed of in MSW landfills.

As the number of HEV vehicles increase, nickel use in HEV NiMH batteries is expected to increase by a factor of 10 by 2010 to about 7,300 t of nickel. Changes in energy prices, technological breakthroughs, and other unanticipated factors may affect the rate and size of this anticipated increase. NiMH batteries will continue to be the most widely used HEV battery in 2010. Based on available data, nickel used in HEV batteries may represent about 1.5 percent of total nickel apparent consumption in the United States in 2010.

\section{References Cited}

Advanced Automotive Batteries, 2006, Hybrid vehicle market overview: Advanced Automotive Batteries, available online at http://www.advancedautobat.com/market.html. (Accessed November 21, 2006.)

Ames, Ben, 2006, Environmental impact minimal from Dell battery recall: IDG News Service, August 21, available online at http://www.computerworld.com.au/ index.php?id=1697068571. (Accessed September 30, 2006.)

Boehme, S.E., and Panero, M.A., 2003, Pollution prevention and management strategies for cadmium in the New York/ New Jersey harbor: New York, Academy of Sciences, 64 p.

Brodd, R.J., 2005, Factors affecting U.S. production decisions - Why are there no volume lithium-ion battery manufacturers in the United States: National Institute of Standards and Technology, Economic Assessment Office, 
Advanced Technology Program Working Paper 05-01, 74 p., available online at $h t t p: / / w w w . a t p . n i s t . g o v / e a o /$ wp05-01/contents.htm. (Accessed March 12, 2007.)

Cao, Xinyu, and Mokhtarian, Patricia, 2004, The future demand for alternative fuel passenger vehicles-A diffusion of innovation approach: University of California, Davis Task Order No. 31 prepared for the California Department of Transportation, June, $117 \mathrm{p}$., available online at http://aqp.engr.ucdavis.edu/Documents/AFV SCENARIO_ June.pdf. (Accessed March 14, 2007.)

Charny, Ben, 2005, U.S. cell tally—180 million users and counting: ZD Net News, available online at http://news.com.com/U.S. + cell + tally $+180+$ million + users + and +counting/2110-1039_3-5615778.html. (Accessed March 12, 2007.)

Cooper, M.E., and Kuck, P.H., 2007, Cadmium, in Metals and minerals: U.S. Geological Survey Minerals Yearbook 2005, v. I, p. 15.1-15.8, (Also available online at http://minerals.usgs.gov/minerals/pubs/commodity/ cadmium/cadmimyb05.pdf.) (Accessed May 3, 2007.)

Environmental Literacy Council, 2004, Life cycle of a cell phone: Environmental Literacy Council Web site, available online at http://www.enviroliteracy.org/article.php/1119.php. (Accessed March 13, 2007.)

Fishbein, B.K., 2002, Waste in the wireless world-The challenge of cell phones: New York, INFORM, Inc., p. 19-23.

Freedonia Group Inc., The, 2006, Global HEV sales forecast of 6,000,000 units by 2015: The Freedonia Group Inc., available online at http://www.johnsoncontrols.com/ documents/media_bg.ppt. (Accessed September 13, 2006.)

Gaines, Linda, and Cuenca, Roy, 2000, Costs of lithium-ion batteries for vehicles: Argonne National Laboratory, Center for Transportation Research ANL/ESD-42, May, 57 p., available online at $h t t p: / / w w w . t r a n s p o r t a t i o n . a n l . g o v / p d f_{s} /$ TA/149.pdf. (Accessed March 13, 2007.)

Gartner, Inc., 2005, Gartner says mobile phone sales will exceed one billion in 2009: Gartner, Inc., avail-

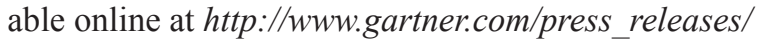
asset_132473_11.html. (Accessed March 20, 2007.)

Geelan, Aron, and Kirkpatrick, Adam [2006], Hybrid carsHow have they improved since introduction?: Corvallis, Oregon State University student presentation available online at http://www.chem.orst.edu/courses/ch407h/ CH407H project 05 adam aron Hybrid Cars.ppt. (Accessed March 20, 2007.)

Hawkins, T.R., Matthews, H.S., and Henderson, Chris, 2006, Closing the loop on cadmium-An assessment of the material cycle of cadmium in the United States: International Journal of Life Cycle Assessment, v. 11, no. 1, p. 38-48.
Kanellos, Michael, 2006, Notebooks pass desktops in U.S. retail: ZD Net News, available online at http://news.zdnet.com/2100-9584_22-6033967.html. (Accessed April 26, 2007.)

Klimasauskas, E.P., Kuck, P.H., and Plunkert, P.A., 2006, Cadmium, in Metals and minerals: U.S. Geological Survey Minerals Yearbook 2004, v. I, p. 15.1-15.8. (Also available online at http://minerals.er.usgs.gov/minerals/pubs/ commodity/cadmium/cadmimyb04.pdf.) (Accessed March 12, 2007.)

Kuck, P.H., 1996, Nickel: U.S. Geological Survey and U.S. Bureau of Mines Mineral Commodity Summaries 1996, p. 114-115. (Also available online at http://minerals.er.usgs.gov/minerals/pubs/mcs/.)

Kuck, P.H., 1997-2007, Nickel: U.S. Geological Survey Mineral Commodity Summaries 1997-2007, variously paginated. (Also available online at http://minerals.er.usgs.gov/ minerals/pubs/mcs/.)

Kuck, P.H., 1996, Cadmium: U.S. Geological Survey and U.S. Bureau of Mines Mineral Commodity Summaries 1996, p. 36-37. (Also available online at http://minerals.er.usgs.gov/ minerals/pubs/mcs/.)

Kuck, P.H., 1997-2007, Cadmium: U.S. Geological Survey Mineral Commodity Summaries 19972007, variously paginated. (Also available online at http://minerals.er.usgs.gov/minerals/pubs/mcs/.)

Kuck, P.H., 2005, Nickel, in Metals and minerals: U.S. Geological Survey Minerals Yearbook 2004, v. I, p. 52.1-52.22. (Also available online at http://minerals.usgs.gov/minerals/pubs/ commodity/nickel/nickemyb04.pdf.) (Accessed May 3, 2007.)

Kuck, P.H., 2007, Nickel: U.S. Geological Survey Mineral Commodity Summaries 2007, p. 112-113. (Also available online at http://minerals.er.usgs.gov/minerals/pubs/ commodity/nickel/nickemcs07.pdf.) (Accessed May 3, 2007.)

Linden, David, 1995, Handbook of batteries (2d ed.): New York, McGraw Hill, 1216 p.

Madani, Ali, 2005, Electric \& hybrid vehicle trends \& impact on the battery market: Paris, Avicenne Développement, Batteries 2005, Paris, June, Presentation, 25 p., available online at http://www.avicenne.com/download/batteries/Electric and Hybrid vehicle trends and impact on the battery market, Batteries 2005, June 2005, A. Madani.pdf. (Accessed November 27, 2006.)

Most, Eric, 2003, Calling all cell phones-Collection, reuse, and recycling programs in the U.S.: New York, INFORM, Inc., 48 p., available online at http://www.infominc.org/ reportpdfs/wp/Calling All Cell Phones.pdf.) (Accessed June 20, 2007.) 
National Economic Council, 2006, Advanced Energy Initiative: National Economic Council, February, 15 p., available online at http://gop.science.house.gov/hot/Competitiveness/ energy_initiative.pdf. (Accessed March 12, 2007.)

Nokia Corporation, 2006, Nokia mobile phones: Nokia U.S.A. Web site at http://nokiausa.com/phones/noflash. (Accessed March 13, 2007.)

Ober, J.A., 1996, Lithium: U.S. Geological Survey and U.S. Bureau of Mines Mineral Commodity Summaries 1996, p. 96-97. (Also available online at http://minerals.er.usgs.gov/minerals/pubs/mcs/.)

Ober, J.A., 1997-2007, Lithium: U.S. Geological Survey Mineral Commodity Summaries 1997-2007, variously paginated. (Also available online at http://minerals.er.usgs.gov/minerals/pubs/mcs/.)

Ober, J.A., 2002, Lithium, in Metals and minerals: U.S. Geological Survey Minerals Yearbook 2000, v. I, p. 47.1-47.8. (Also available online at http://minerals.usgs.gov/minerals/pubs/ commodity/lithium/450400.pdf.) (Accessed June 20, 2007.)

Ober, J.A., 2003, Lithium, in Metals and minerals: U.S. Geological Survey Minerals Yearbook 2001, v. I, p. 46.1-46.7. (Also available online at http://minerals.usgs.gov/minerals/pubs/ commodity/lithium/450401.pdf.) (Accessed June 20, 2007.)

Ober, J.A., 2004, Lithium, in Metals and minerals: U.S. Geological Survey Minerals Yearbook 2002, v. I, p. 46.1-46.7. (Also available online at http://minerals.usgs.gov/minerals/pubs/ commodity/lithium/lithmyb02.pdf.) (Accessed June 20, 2007.)

Ober, J.A., 2005, Lithium, in Metals and minerals: U.S. Geological Survey Minerals Yearbook 2003, v. I, p. 45.1-45.8. (Also available online at $h t t p: / / m i n e r a l s . u s g s . g o v / m i n e r a l s / p u b s /$ commodity/lithium/lithmyb03.pdf.) (Accessed June 20, 2007.)

Ober, J.A., 2006, Lithium, in Metals and minerals: U.S. Geological Survey Minerals Yearbook 2004, v. I, p. 45.1-45.7. (Also available online at http://minerals.usgs.gov/minerals/pubs/ commodity/lithium/lithimyb04.pdf.) (Accessed June 20, 2007.)

Ober, J.A., 2007, Lithium, in Metals and minerals: U.S. Geological Survey Minerals Yearbook 2005, v. I, p. 45.1-45.7. (Available online at http://minerals.usgs.gov/minerals/pubs/ commodity/lithium/lithimyb05.pdf.) (Accessed June 20, 2007.)

Panasonic EV Energy Co. Ltd., 2006, Plastic case prismatic module: Panasonic EV Energy Co. Ltd. Web site, available online at http://www.peve.jp/e/hevjyusi.html. (Accessed March 14, 2007.)

Paumanok Publications Inc., 2006, Global car, light truck, and heavy truck production forecasts 1995-2005, 2006F: TTI, Inc. Web site, available online at http://www.ttinc.com/ object/me_zogbi_20060710.html. (Accessed November 7, 2006.)
Pesaran, Ahmad, 2006, Battery choices for different plugin HEV configurations: Presentation at Plug-in HEV forum and technical roundtable, Diamond Bar, Calif., July 12, available online at $h t t p: / / w w w . a q m d . g o v / t a o /$ ConferencesWorkshops/PHEV_Forum-07-12-06/4AhmadPesaran-NREL-revised.pdf. (Accessed September 13, 2006.)

Pillot, Christophe, 2004, The worldwide rechargeable battery market 2003-08: Paris, Avicenne Développement, Batteries 2004, Brussels, April, Presentation, 32 p., available online at http://www.avicenne.com/download/batteries/ The Worldwide Recharge Brussels, April, 2004, Pillot.pdf. (Accessed April 24, 2006.)

Pillot, Christophe, 2005a, Growth forecasts and evolution for small fuel cells and cartridges: Paris, Avicenne Développement, 22nd Annual International Battery seminar, Fort Lauderdale, March, Presentation, 18 p., available online at http://www.avicenne.com/download/batteries/ Growth Forecasts and Evolution for Small Fuel Cells and Cartridges, The 22nd International Battery Seminar and Exhibit, Florida, March 2005, Pillot.pdf. (Accessed November 27, 2006.)

Pillot, Christophe, 2005b, Main trends for the rechargeable battery market worldwide 2004-2010: Paris, Avicenne Développement, Batteries 2005, Paris, June 14-16, Presentation, 26 p., available online at http://www.avicenne.com/download/batteries/Main Trends for the Battery Market 2004-2010, Batteries 2005, June 2005, Pillot.pdf. (Accessed November 27, 2006.)

Pillot, Christophe, 2006a, Electric \& hybrid vehicle trends \& impact on the battery market: Paris, Avicenne Développement, 23rd Annual International Battery seminar, Fort Lauderdale, March, Presentation, 25 p., available online at http://www.avicenne.com/gb/batteries_and_power_supply publications.htm\#articles_and_presentations. (Accessed April 25, 2007.)

Pillot, Christophe, 2006b, Main trends for the rechargeable battery market worldwide 2005-2015: Batteries 2006, Paris, June, Presentation, 25 p., available online at http://www.avicenne.com/gb/batteries_and_power_supply_ publications.htm. (Accessed April 25, 2007.)

Ramamoorthy, Hari, 2006, Moore's law of electronic recycling: Resource Recycling, v. 25, no. 10, October 2006, p. 31.

Rechargeable Battery Recycling Corporation, 2005, New survey reveals the 'skinny' on what Americans stockpile in their closets: Atlanta, Ga., Rechargeable Battery Recycling Corporation press release November 21, available online at http://www.rbrc.org/call2recycle/releases/ PR_11_21_05.html. (Accessed April 20, 2006)

Rydh, C.J., and Svard, Bo, 2003, Impact on global metal flows arising from the use of portable rechargeable batter- 
ies: Science of the Total Environment, v. 302, January 20, p. $167-184$.

Shedd, K.B., 2007, Cobalt, in Metals and minerals: U.S. Geological Survey Minerals Yearbook 2005, v. I, p. 19.1-19.19. (Also available online at http://minerals.usgs.gov/minerals/pubs/ commodity/cobalt/cobalmyb05.pdf.) (Accessed May 3, 2007.)

Sullivan, D.E., 2006, Recycled cell phones-A treasure trove of valuable metals: U.S. Geological Survey Fact Sheet 2006-3097, 4 p. (Also available online at http://pubs.usgs.gov/fs/2006/3097/fs2006-3097.pdf.) (Accessed March 3, 2007.)

U.S. Consumer Product Safety Commission, 2007, News from CPSC: Washington, Office of Information and Public Affairs press releases, available online at $h t t p: / / c p s c . g o v /$. (Accessed April 25, 2007.)

U.S. Department of Energy, 2006, Table 45, in Annual energy outlook 2006 with projections to 2030-Supplemental tables to the annual energy outlook 2006: U.S. Department of Energy, Energy Information Administration, available online at http://www.eia.doe.gov/oiaf/aeo/supplement/pdf/ sup_trans.pdf. (Accessed March 14, 2007.)

U.S. Department of Transportation, 2006, Tables T1-16, T1-17, T1-22, in National transportation statistics: U.S. Department of Transportation, Bureau of Transportation Statistics, , available online at http://www.bts.gov/ publications/national_transportation_statistics. (Accessed March 14, 2007.)

U.S. Environmental Protection Agency, 2000, Cadmium compounds-Hazard summary: U.S. Environmental Protection Agency, Technology Transfer Network Air Toxics Web site at http://www.epa.gov/ttn/atw/hlthef/cadmium.html. (Accessed March 12, 2007.)

U.S. Environmental Protection Agency, 2002a, The 'Battery Act'-Law creates public health, environmental safeguards through phase-out of mercury batteries and other important requirements: U.S. Environmental Protection Agency, Office of Regulatory Enforcement, Enforcement Alert Newsletter, v. 5, no. 2, March, available online at http://www.epa.gov/compliance/resources/newsletter/civil/ enfalert/battery.pdf. (Accessed March 12, 2007.)
U.S. Environmental Protection Agency, 2002b, Characterization of products containing lead and cadmium in municipal solid waste in the United States, 1970 to 2000: U.S. Environmental Protection Agency, Office of Solid Waste Final Report EPA/5S30-SW-015A, 220 p., available online at $h t t p: / / w w w . p 2 p a y s . o r g / r e f / 02062 . p d f$. (Accessed June 7, 2006.)

U.S. Environmental Protection Agency, 2005, eCycling-2005 facts and figures: U.S. Environmental Protection Agency, available online at $h t t p: / / w w w . e p a . g o v / e p a o s w e r / h a z w a s t e /$ recycle/ecycling/index.htm. (Accessed March 13, 2007.)

U.S. Geological Survey, 2005, Cadmium, cobalt, and nickel statistics, in Kelly, T.D., and Matos, G.R., comps., Historical statistics for mineral and material commodities in the United States (ver. 1.1): U.S. Geological Survey Data Series 2005-140, available online at http://pubs.usgs.gov/ ds/2005/140/. (Accessed March 21, 2007.)

U.S. International Trade Commission, 2006, Interactive tariff and trade DataWeb: U.S. International Trade Commission, available online at http://dataweb.usitc.gov/. (Accessed November 27, 2006.)

Vangheluwe, Marnix, Verdonck, Frederik, and Versonnen, Bram, 2005, Contribution of spent batteries to the metal flows of municipal solid waste: Brussels, European Academy of Standardization, October, 79 p., available online at http://www.rechargebatteries.org/RelDoc_Metals_flow_of_ MSW_2005_FL.pdf. (Accessed April 24, 2006.)

Wilburn, D.R., and Buckingham, D.A., 2006, Apparent consumption vs. total consumption-A lead-acid battery case study: U.S. Geological Survey Scientific Investigations Report 2006-5155, 9 p. (Available only online at http://pubs.usgs.gov/sir/2006/5155/sir20065155.pdf.) (Accessed March 3, 2007.)

Wilburn, D.R., 2007, U.S. materials consumption-Cadmium in rechargeable batteries-A U.S. materials flow study: U.S. Geological Survey Scientific Investigations Report 2007-5198, 32 p. (Available only online at http://pubs.usgs.gov/sir/2007/2007-5198/ SIR2007-5198-508.pdf.) (Accessed March 3, 2007.) 


\section{Appendix}

The appendix lists the assumptions and estimates used in this study. Table A-1 summarizes material content assumptions and estimates for nickel-cadmium batteries; table A-2 summarizes material content assumptions and estimates for primary lithium-based batteries; table A-3 summarizes material content assumptions and estimates for nickel-metal-hydride batteries; and table A-4 summarizes material content assumptions and estimates for lithium-ion and lithium-polymer batteries. Manufacturers' data were derived from selected Material Safety Data Sheets, which where publicly available from battery manufacturers having a sizeable U.S. presence. Average battery weights and material contents for each HTS classification applicable to each manufactured product under review were developed from these data. Table A-5 summarizes specific material content assumptions for cell phone batteries; table A-6 summarizes specific material content assumptions for portable (laptop) computer batteries; table A-7 summarizes specific material content assumptions for camera batteries; table A-8 summarizes specific material content assumptions for video camera (camcorder) batteries; and table A-9 summarizes material content assumptions for batteries designated for hybrid vehicles considered in this study.

HTS classes applied to each end use are listed for nickel-cadmium batteries in table A-10 and for lithium-ion and nickel-metal-hydride batteries in table A-11. Some classifications apply only to either export or import data; most apply to both export and import data. Tables A-10 and A-11 report the years for which each HTS class was applicable for the study period, and whether the class applies to export data, import data, or both. 
Table A-1. Selected material content assumptions and estimates for nickel-cadmium batteries used in this study to determine the flow of cadmium in the United States from 1996 through 2005.

[NA, not available; XX, not applicable; - zero]

\begin{tabular}{|c|c|c|c|c|c|c|c|c|c|c|c|}
\hline Battery class (based on end use) & $\begin{array}{l}\text { Manufacturer } \\
\text { and/or battery type }\end{array}$ & $\begin{array}{l}\text { Cell weight } \\
\text { range }^{2} \text {, in grams }\end{array}$ & $\begin{array}{l}\text { Average } \\
\text { weight of } \\
\text { cell }{ }^{2} \text {, in } \\
\text { grams }\end{array}$ & $\begin{array}{l}\text { Cadmium } \\
\text { content }{ }^{2} \text {, in } \\
\text { percent }\end{array}$ & $\begin{array}{l}\text { Cadmium } \\
\text { content/cell } \\
\text { or pack }{ }^{3} \text {, in } \\
\text { grams }\end{array}$ & $\begin{array}{l}\text { Cobalt } \\
\text { content }{ }^{2} \text {, } \\
\text { percent }\end{array}$ & $\begin{array}{c}\text { Cobalt } \\
\text { content/cell } \\
\text { or pack }{ }^{3} \text {, in } \\
\text { grams }\end{array}$ & $\begin{array}{l}\text { Nickel } \\
\text { content }{ }^{2} \text {, } \\
\text { percent }\end{array}$ & $\begin{array}{c}\text { Nickel } \\
\text { content/cell } \\
\text { or pack }{ }^{3} \text {, in } \\
\text { grams }\end{array}$ & $\begin{array}{l}\text { Nickel-cadmium, } \\
\text { in percentage of } \\
\text { total estimate }^{4}\end{array}$ & $\begin{array}{l}\text { Years for } \\
\text { which data } \\
\text { applied }\end{array}$ \\
\hline $\begin{array}{l}\text { General nickel-cadmium storage batterv }{ }^{5} \\
\text { Storage batteries, separate: }\end{array}$ & NA & $\mathrm{NA}$ & NA & 14 & NA & 0 & NA & 22 & NA & $\mathrm{NA}$ & $1996-2005$ \\
\hline Electrically-powered vehicle batteries & Saft STM & $12,900-17,000$ & 14,400 & 16 & 2,300 & 1 & 100 & 22 & 3,200 & 100 & 1996-2005 \\
\hline \multirow{2}{*}{ Sealed consumer batteries } & Saft VRE & 19-150 & 60 & $10-15$ & 8.4 & $0.4-1$ & 0.4 & $20-28$ & 13.2 & 100 & 1996-2005 \\
\hline & Sanyo Cadnica & NA & NA & $11-26$ & NA & 0 & 0 & $13-29$ & NA & 100 & 1996-2005 \\
\hline \multirow[t]{2}{*}{ Industrial batteries } & Saft SLM & $1,000-45,000$ & 14,900 & 8 & 1,200 & 0.2 & 30 & 9 & 1,300 & 100 & 1996-2005 \\
\hline & Saft SPH & NA & NA & 16 & NA & 1 & 0 & 22 & NA & 100 & 1996-2005 \\
\hline \multicolumn{12}{|l|}{ Batteries enclosed in products: } \\
\hline Power tools & Saft VRE-C & NA & 43 & $10-15$ & 6 & $0.4-1$ & 0.3 & $20-28$ & 9.5 & 91 & 1996-2005 \\
\hline Cordless phones & Batterv selection $^{6}$ & $63-113$ & 80 & 14 & 11.2 & 0.9 & 0.7 & 22 & 17.6 & 40 & 1996-2005 \\
\hline \multirow[t]{3}{*}{ Camcorders } & Batterv selection ${ }^{6}$ & $59-376$ & 160 & 14 & 22 & 0.9 & 1.4 & 22 & 35 & 30 & 1996-2003 \\
\hline & $\mathrm{XX}$ & $\mathrm{XX}$ & $\mathrm{XX}$ & $\mathrm{XX}$ & $\mathrm{XX}$ & $\mathrm{XX}$ & $\mathrm{XX}$ & $\mathrm{XX}$ & $\mathrm{XX}$ & 18 & 2004 \\
\hline & $\mathrm{XX}$ & XX & $\mathrm{XX}$ & $\mathrm{XX}$ & $\mathrm{XX}$ & $\mathrm{XX}$ & $\mathrm{XX}$ & $\mathrm{XX}$ & $\mathrm{XX}$ & 6 & 2005 \\
\hline Cameras & Batterv selection ${ }^{6}$ & $20-318$ & 130 & 14 & 19 & 0.5 & 0.5 & 22 & 29 & 30 & 1996-1999 \\
\hline \multirow[t]{2}{*}{ Portable radios } & Saft VRE-AA & $14-32$ & 21 & $10-15$ & 2.9 & $0.4-1$ & 0.1 & $20-28$ & 4.6 & 6 & 1996-2005 \\
\hline & Sanyo Cadnica-AA & NA & NA & $11-26$ & NA & 0 & 0 & $13-29$ & NA & 6 & 1996-2005 \\
\hline \multirow[t]{3}{*}{ Shavers } & Saft VRE-AA & $14-32$ & 21 & $10-15$ & 2.9 & $0.4-1$ & 0.1 & $20-28$ & 4.6 & 45 & 1996-2003 \\
\hline & Sanyo Cadnica-AA & NA & NA & $11-26$ & $\mathrm{NA}$ & 0 & 0 & $13-29$ & $\mathrm{NA}$ & 34 & 2004 \\
\hline & $\mathrm{XX}$ & $\mathrm{XX}$ & $\mathrm{XX}$ & $\mathrm{XX}$ & $\mathrm{XX}$ & $\mathrm{XX}$ & $\mathrm{xX}$ & $\mathrm{XX}$ & $\mathrm{XX}$ & 22 & 2005 \\
\hline \multirow[t]{3}{*}{ Electric toothbrushes } & Saft VRE-AA & $14-32$ & 21 & $10-15$ & 2.9 & $0.4-1$ & 0.1 & $20-28$ & 4.6 & 45 & 1996-2003 \\
\hline & Sanyo Cadnica-AA & NA & NA & $11-26$ & $\mathrm{NA}$ & 0 & 0 & $13-29$ & NA & 34 & 2004 \\
\hline & $\mathrm{XX}$ & $\mathrm{XX}$ & $\mathrm{XX}$ & $\mathrm{XX}$ & $\mathrm{XX}$ & $\mathrm{XX}$ & $\mathrm{xX}$ & $\mathrm{XX}$ & $\mathrm{XX}$ & 22 & 2005 \\
\hline \multirow[t]{3}{*}{ Portable vacuum cleaners } & Saft VRE-Cs & $43-150$ & 97 & $10-15$ & 13.6 & $0.4-1$ & 0.7 & $20-28$ & 21.3 & 45 & 1996-2003 \\
\hline & Saft VRE-D & NA & NA & $10-15$ & NA & $0.4-1$ & NA & $20-28$ & NA & 34 & 2004 \\
\hline & $\mathrm{XX}$ & XX & $\mathrm{XX}$ & $\mathrm{XX}$ & $\mathrm{XX}$ & $\mathrm{XX}$ & $\mathrm{XX}$ & $\mathrm{XX}$ & $\mathrm{XX}$ & 22 & 2005 \\
\hline \multirow[t]{5}{*}{ Flashlights } & Sanyo Cadnica & $19-145$ & 49 & $11-26$ & 6.9 & 0 & 0 & $13-29$ & 10.8 & 4 & 1996-2003 \\
\hline & $\mathrm{XX}$ & $\mathrm{XX}$ & $\mathrm{XX}$ & $\mathrm{XX}$ & $\mathrm{XX}$ & $\mathrm{XX}$ & $\mathrm{xX}$ & $\mathrm{XX}$ & $\mathrm{XX}$ & 3 & 2004 \\
\hline & $\mathrm{XX}$ & $\mathrm{xX}$ & $\mathrm{XX}$ & $\mathrm{XX}$ & $\mathrm{XX}$ & $\mathrm{XX}$ & $\mathrm{xX}$ & $\mathrm{XX}$ & $\mathrm{xX}$ & 2 & 2005 \\
\hline & Energizer & NA & NA & $13-22$ & NA & $0.5-2$ & NA & $20-32$ & NA & - & 1996-2005 \\
\hline & Panasonic & $26-51$ & 40 & NA & NA & NA & NA & NA & $\mathrm{NA}$ & - & 1996-2005 \\
\hline \multirow{3}{*}{$\begin{array}{l}\text { Portable electric lamps (bicycle lamps, for } \\
\text { example) }\end{array}$} & Saft VE & $18-150$ & 64 & $10-15$ & 9 & $0.4-1$ & 0.4 & $20-28$ & 14 & 24 & 1996-2003 \\
\hline & $\mathrm{XX}$ & $\mathrm{XX}$ & $\mathrm{XX}$ & $\mathrm{XX}$ & $\mathrm{XX}$ & $\mathrm{XX}$ & $\mathrm{xX}$ & $\mathrm{XX}$ & $\mathrm{XX}$ & 18 & 2004 \\
\hline & $\mathrm{XX}$ & $\mathrm{XX}$ & $\mathrm{XX}$ & $\mathrm{XX}$ & $\mathrm{XX}$ & $\mathrm{XX}$ & $\mathrm{xX}$ & $\mathrm{XX}$ & $\mathrm{XX}$ & 12 & 2005 \\
\hline \multirow[t]{3}{*}{ Clock batteries, reported separately } & Saft VRE-AA & $14-32$ & 21 & $10-15$ & 2.9 & $0.4-1$ & 0.1 & $20-28$ & 4.6 & 4 & 1996-2003 \\
\hline & Sanyo Cadnica-AA & NA & NA & $11-26$ & NA & 0 & 0 & $13-29$ & NA & 3 & 2004 \\
\hline & $\mathrm{XX}$ & $\mathrm{XX}$ & $\mathrm{XX}$ & $\mathrm{XX}$ & $\mathrm{XX}$ & $\mathrm{XX}$ & $\mathrm{xX}$ & $\mathrm{XX}$ & $\mathrm{XX}$ & 2 & 2005 \\
\hline \multirow[t]{2}{*}{ Military batteries, reported separately } & Saft VRE-AA & $14-32$ & 21 & $10-15$ & 2.9 & $0.4-1$ & 0.1 & $20-28$ & 4.6 & 16 & 1996-2005 \\
\hline & Sanyo Cadnica-AA & $\mathrm{NA}$ & NA & $11-26$ & $\mathrm{NA}$ & 0 & 0 & $13-29$ & $\mathrm{NA}$ & 16 & 1996-2005 \\
\hline
\end{tabular}

Manufacturer was selected based on the volume of production and the availability of data. Battery selection was based on the applicability to the end-use category. Batteries selected are assumed to be representative for the given classification.

Based on reported weights given by the manufacturer for all batteries in that classification. Data were obtained from the specified manufacturer's Web site.

${ }^{3}$ Calculated using (average weight of cell or pack) $\times$ (specified commodity content). When a percent range is shown, the average percentage reported by Vangheluwe, Verdonck, and Versonnen (2005) was used for calculations.

${ }^{4}$ Percent allocation of the number of batteries listed as nickel-cadmium batteries, based on end-use distributions reported by Pillot (2004, p. 29-31; 2005a, p. 5-8). In some cases, the 2004 and 2005 percentages were reported to be lower than the percentages of previous years. Where no years are reported, value applies to entire study period.

${ }^{5}$ Vangheluwe, Verdonck, and Versonnen (2005).

${ }^{6}$ Based on a random selection of batteries used for each of these applications (Zbattery.com, written commun., November 22, 2006). 
Table A-2. Selected material content assumptions and estimates for primary lithium-based batteries used in this study.

\begin{tabular}{|c|c|c|c|c|c|c|}
\hline Battery class (based on chemistry) & Battery type ${ }^{1}$ & Manufacturer $^{1}$ & $\begin{array}{c}\text { Cell weight/range }{ }^{2} \text {, in } \\
\text { grams }\end{array}$ & $\begin{array}{c}\text { Average weight of } \\
\text { cell }^{2} \text {, in grams }\end{array}$ & $\begin{array}{l}\text { Lithium content }{ }^{2} \text {, } \\
\text { in percent }\end{array}$ & $\begin{array}{l}\text { Lithium content per } \\
\text { cell }^{3} \text {, in grams }\end{array}$ \\
\hline Manganese-dioxide-lithium primary (alkaline & CR coin type & Sanyo Electric Co. Ltd. & $0.8-6.9$ & 3.2 & $\sim 3$ & 0.065 \\
\hline \multirow[t]{24}{*}{ type) } & $\mathrm{CR}$ coin type & Energizer Battery Manufacturing Inc. & $0.7-6.9$ & 2.4 & $1-6$ & 0.051 \\
\hline & $\mathrm{CR}$ coin type & Sony Corporation & $0.7-10$ & 3.2 & NA & 0.096 \\
\hline & $\mathrm{CR}$ coin type & Panasonic Corp. & $0.7-6.8$ & 2.6 & NA & 0.078 \\
\hline & Button/coin type & AA Portable Power Corp. & $0.7-10.5$ & 2.8 & NA & 0.084 \\
\hline & BR cylindrical type & Sanyo Electric Co. Ltd. & $3.3-38$ & 20.7 & $\sim 3$ & 0.64 \\
\hline & SE cylindrical type & Sanyo Electric Co. Ltd. & $9-42$ & 21 & NA & 0.69 \\
\hline & CR cylindrical type & Energizer Battery Manufacturing Inc. & $3-40$ & 23 & NA & 0.73 \\
\hline & LM series cylindrical type $3.2 \mathrm{~V}$ & Saft Group SA & $2.9-6$ & 4.3 & $\sim 3.3$ & 0.142 \\
\hline & AAA size cylindrical type & Panasonic Corp. & 11 & 11 & NA & NA \\
\hline & AAA size & U.S. average (1996) & NA & 12 & NA & NA \\
\hline & AA size & U.S. average (1996) & NA & 30 & NA & NA \\
\hline & AA size cylindrical type & Panasonic Corp. & 23 & 23 & NA & 0.69 \\
\hline & C size & U.S. average (1996) & NA & 70 & NA & NA \\
\hline & C size cylindrical type & Panasonic Corp. & 70 & 70 & NA & NA \\
\hline & C size cylindrical type & Ultralife Batteries Inc. & 61 & 61 & $1-4$ & 1.52 \\
\hline & LM series cylindrical type C-cell & Saft Group SA & 55 & 55 & $\sim 3.3$ & 1.81 \\
\hline & D size & U.S. average (1996) & NA & 140 & NA & NA \\
\hline & D size cylindrical type & Panasonic Corp. & 141 & 141 & NA & NA \\
\hline & D size cylindrical type & Ultralife Batteries Inc. & 115 & 115 & $3-4$ & 4 \\
\hline & LM series cylindrical type D-cell & Saft Group SA & 116 & 116 & $\sim 3.3$ & 3.8 \\
\hline & $9 \mathrm{~V}$ type & Ultralife Batteries Inc. & $33.8-36.4$ & 35 & $1-4$ & 0.87 \\
\hline & $9 \mathrm{~V}$ size & U.S. average (1996) & NA & 50 & NA & NA \\
\hline & Prismatic type & Ultralife Batteries Inc. & $3.5-15$ & 9 & $5-8$ & 0.59 \\
\hline & Military type & Ultralife Batteries Inc. & $10-61$ & 44 & $1-4$ & 1.1 \\
\hline Lithium iron disulfide primary & Cylindrical type & Energizer Battery Manufacturing Inc. & $34-36$ & 35 & $5-8$ & 1.35 \\
\hline \multirow[t]{2}{*}{ Lithium thionyl chloride primary } & LS/LST series cylindrical type & Saft Group SA & $8.9-23.5$ & 14.4 & $3.5-5$ & 0.61 \\
\hline & LSH series cylindrical type & Saft Group SA & $24-100$ & 65 & $3.5-5$ & 2.76 \\
\hline Lithium sulfur dioxide primary & LO/G series cylindrical type & Saft Group SA & $8-300$ & 72 & $<3$ & 2.1 \\
\hline
\end{tabular}

${ }^{1}$ Manufacturer was selected based on the volume of production and the availability of data. Battery selection was based on the applicability to the end-use category. Batteries selected are assumed to be representative for the given classification.

${ }^{2}$ Based on reported weights of cell or pack given by the manufacturer for all batteries in that classification. Data were obtained from the specified manufacturer's Web site.

${ }^{3}$ Calculated from (average weight of cell or pack) $\times$ (specified commodity content). When a percent range is shown, the average weight percentage was derived by averaging all batteries of similar type. 
Table A-3. Selected material content assumptions and estimates for nickel-metal-hydride batteries used in this study. [e, estimate; NA, not available]

\begin{tabular}{|c|c|c|c|c|c|c|c|}
\hline Battery type ${ }^{1}$ & Manufacturer $^{1}$ & $\begin{array}{l}\text { Cell weight } \\
\text { range }^{2} \text {, in } \\
\text { grams }\end{array}$ & $\begin{array}{c}\text { Average } \\
\text { weight of cell } \\
\text { or pack }{ }^{2} \text { in } \\
\text { grams }\end{array}$ & $\begin{array}{l}\text { Cobalt content } \\
\text { from Co or } \\
\mathrm{LiCo}(\mathrm{OH})_{2}{ }^{2} \text {, in } \\
\text { percent }\end{array}$ & $\begin{array}{l}\text { Cobalt } \\
\text { content/ } \\
\text { cell }{ }^{3} \text {, in } \\
\text { grams }\end{array}$ & $\begin{array}{l}\text { Nickel } \\
\text { content }^{2} \text {, } \\
\text { in } \\
\text { percent }\end{array}$ & $\begin{array}{l}\text { Nickel } \\
\text { content/c } \\
\text { ell or } \\
\text { pack }^{3} \text {, in } \\
\text { grams }\end{array}$ \\
\hline AA size cylindrical type & Saft Group SA & $25-26$ & 25.5 & $0.6-3$ & 0.56 & $30-45$ & 9.4 \\
\hline $\mathrm{C}$ size cylindrical type & Saft Group SA & 59 & 59 & $0.6-3$ & 1.3 & $30-45$ & 22 \\
\hline D size cylindrical type & Saft Group SA & 160 & 160 & $0.6-3$ & 3.5 & $30-45$ & 59 \\
\hline D size hybrid vehicle type & Sanyo/Saft & NA & 43,600 & $0.4-1 \mathrm{e}$ & 300 & 40 & 17,000 \\
\hline D size hybrid vehicle type & Matsushita/Panasonic & NA & 39,500 & NA & NA & 35.5 & 14,000 \\
\hline Cylindrical type battery pack & Panasonic Corp. & $12-170$ & 51 & NA & NA & NA & NA \\
\hline Cylindrical type & Energizer Battery Manufacturing Inc. & NA & NA & $1.5-3.6$ & NA & $30-50$ & NA \\
\hline Button type & AA Portable Power Corp. & $1.8-13$ & 6.9 & NA & NA & NA & NA \\
\hline Prismatic type & AA Portable Power Corp. & $9-26$ & 18 & NA & NA & NA & NA \\
\hline Button type & Linden, David, 1995: Handbook of Batteries, 1995, p. 33.28 & NA & NA & NA & NA & NA & NA \\
\hline Cylindrical type & Linden, David, 1995: Handbook of Batteries, 1995, p. 33.28 & $25-52$ & 37 & NA & NA & NA & NA \\
\hline Prismatic type & Linden, David, 1995: Handbook of Batteries, 1995, p. 33.28 & $17-24$ & 21 & NA & NA & NA & NA \\
\hline Average of all types & $\begin{array}{l}\text { Rydh and Svard, 2003, Impact on global metal flows arising from the } \\
\text { use of portable rechargeable batteries: table 3, p. } 172 \text {. }\end{array}$ & NA & NA & $2.5-4.3$ & NA & $25-46$ & NA \\
\hline
\end{tabular}

${ }^{1}$ Manufacturer was selected based on the volume of production and the availability of data. Battery selection was based on the applicability to the end-use category. Batteries selected are assumed to be representative for the given classification.

${ }^{2}$ Based on reported weights of cell or pack given by the manufacturer for all batteries in that classification. Data were obtained from the specified manufacturer's Web site.

${ }^{3}$ Calculated from (average weight of cell or pack) $\times$ (specified commodity content). When a percent range is shown, the average weight percentage was derived by averaging all batteries of similar type. 
Table A-4. Selected material content assumptions and estimates for lithium-ion and lithium-polymer batteries used in this study.

[AH, amp-hours; g, grams; NA, not available]

\begin{tabular}{|c|c|c|c|c|c|c|c|c|}
\hline $\begin{array}{l}\text { Battery class (based on } \\
\text { chemistry) }\end{array}$ & Battery type $^{1}$ & Manufacturer $^{1}$ & $\begin{array}{c}\text { Cell or pack } \\
\text { weight range }{ }^{2} \text {, in } \\
\text { grams }\end{array}$ & $\begin{array}{l}\text { Average } \\
\text { weight of } \\
\text { cell or } \\
\text { pack }^{2} \text {, in } \\
\text { grams }\end{array}$ & $\begin{array}{c}\text { Cobalt } \\
\text { content from } \\
\text { Co or } \\
\text { LiCo }(\mathrm{OH})_{2}{ }_{2} \text {, in } \\
\text { percent }\end{array}$ & $\begin{array}{c}\text { Cobalt } \\
\text { content/c } \\
\text { ell }{ }^{3} \text {, in } \\
\text { grams }\end{array}$ & $\begin{array}{l}\text { Lithium } \\
\text { content } \\
\text { from Li or } \\
\mathrm{LiCoO}_{2}{ }^{2} \text {, in } \\
\text { percent }\end{array}$ & $\begin{array}{l}\text { Lithium } \\
\text { content/cel } \\
\text { I or pack } \\
\text { in grams }\end{array}$ \\
\hline \multirow[t]{14}{*}{$\begin{array}{l}\text { Lithium cobalt dioxide ion } \\
\text { rechargeable }\end{array}$} & $\begin{array}{l}\text { Theoretical equivalent } \\
\text { lithium content }\end{array}$ & Source: Linden, 1995 , p. 36.48 & NA & NA & $\mathrm{NA}$ & NA & NA & $\begin{array}{r}0.3 \times \\
\text { capacity } \\
(\mathrm{AH})\end{array}$ \\
\hline & Cylindrical type & Panasonic Corp. & $42-46.5$ & 44.8 & NA & NA & NA & NA \\
\hline & Cylindrical type & Sanyo Electric Co. Ltd. & $15-21$ & 18.6 & 15 & 2.8 & 1.8 & $0.34 \mathrm{~g} /$ cell \\
\hline & Cylindrical type & Sanyo Electric Co. Ltd. & $15-80$ & 36.7 & 15 & 5.5 & 1.8 & $0.66 \mathrm{~g} /$ cell \\
\hline & Cylindrical type & Ultralife Batteries Inc. & $15-41$ & 22.6 & 20 & 4.5 & 2.4 & $0.55 \mathrm{~g} /$ cell \\
\hline & Cylindrical type & Source: Linden, 1995 , p. 36.48 & $18-39$ & 30 & NA & NA & NA & NA \\
\hline & LC cylindrical type & AA Portable Power Corp. & $5.6-53$ & 26 & $15-24$ & 5.1 & $1.8-2.8$ & $0.6 \mathrm{~g} /$ cell \\
\hline & LC cylindrical type & Sanyo Electric Co. Ltd. & $11.5-46$ & 22.2 & $15-24$ & 4.3 & $1.8-2.8$ & $0.51 \mathrm{~g} /$ cell \\
\hline & Prismatic type & Source: Linden, 1995 , p. 36.48 & $20-65$ & 41.5 & NA & NA & NA & NA \\
\hline & Prismatic type & Panasonic Corp. & $15-40$ & 25 & NA & NA & NA & NA \\
\hline & Prismatic type & AA Portable Power Corp. & $13.5-39.6$ & 25 & NA & NA & NA & NA \\
\hline & Prismatic type & $\begin{array}{l}\text { Energizer Battery } \\
\text { Manufacturing Inc. }\end{array}$ & NA & NA & $9-18$ & NA & $1.1-2.1$ & NA \\
\hline & MP series prismatic type & Saft Group SA & $68-153$ per pack & $\begin{array}{r}117 \text { per } \\
\text { pack }\end{array}$ & 18 & $\begin{array}{r}21 \text { per } \\
\text { pack }\end{array}$ & $\sim 2.1 \%$ & $2.46 \mathrm{~g} /$ cell \\
\hline & $\begin{array}{l}\text { VLE series hybrid vehicle } \\
\text { battery pack }\end{array}$ & Saft Group SA & $\begin{array}{r}8,000 \text { per module } \times \\
5 \text { modules }\end{array}$ & $\begin{array}{r}40,000 \text { per } \\
\text { pack }\end{array}$ & 18 & $\begin{array}{r}7,200 \text { per } \\
\text { pack }\end{array}$ & $\sim 2.1 \%$ & $860 \mathrm{~g} /$ pack \\
\hline \multirow[t]{4}{*}{$\begin{array}{l}\text { Lithium-ion industrial battery } \\
\text { pack }\end{array}$} & VLM series & Saft Group SA & $770-1070$ per pack & $\begin{array}{r}920 \text { per } \\
\text { pack }\end{array}$ & 18 & $\begin{array}{r}166 \text { per } \\
\text { pack }\end{array}$ & $\sim 2.1 \%$ & $19 \mathrm{~g} /$ cell \\
\hline & VLP series & Saft Group SA & $\begin{array}{r}370-1,100 \text { per } \\
\text { pack }\end{array}$ & $\begin{array}{r}760 \text { per } \\
\text { pack }\end{array}$ & 18 & $\begin{array}{r}137 \text { per } \\
\text { pack }\end{array}$ & $\sim 2.1 \%$ & $16 \mathrm{~g} /$ cell \\
\hline & Military type & Ultralife Batteries Inc. & $925-1440$ & 1146 & $15-24$ & 223 & $1.8-2.8$ & $26 \mathrm{~g} / \mathrm{cell}$ \\
\hline & Military type & $\begin{array}{l}\text { Matsushita Battery Industrial } \\
\text { Co. Ltd. }\end{array}$ & NA & NA & $12-19$ & NA & $1.4-2.5$ & NA \\
\hline \multirow{3}{*}{$\begin{array}{l}\text { Lithium cobalt dioxide polymer } \\
\text { rechargeable }\end{array}$} & UPF series prismatic type & Sanyo Electric Co. Ltd. & $8.3-46$ & 21.7 & $6-12$ & $0.5-5.5$ & $1.1-2.2$ & $0.36 \mathrm{~g} /$ cell \\
\hline & Prismatic type & Ultralife Batteries Inc. & $3-85$ & 17 & $1.8-2.6$ & 0.37 & $15-21$ & $3.1 \mathrm{~g} /$ cell \\
\hline & Prismatic type & Ascent Battery Supply Corp. & NA & NA & $15-18$ & NA & $1.8-2.1$ & NA \\
\hline
\end{tabular}

${ }^{1}$ Manufacturer was selected based on the volume of production and the availability of data. Battery selection was based on the applicability to the end-use category. Batteries selected are assumed to be representative for the given classification.

${ }^{2}$ Based on reported weights of cell or pack given by the manufacturer for all batteries in that classification. Data were obtained from the specified manufacturer's Web site.

${ }^{3}$ Calculated from (average weight of cell or pack) $\times$ (specified commodity content). When a percent range is shown, the average weight percentage was derived by averaging all batteries of similar tvpe. 
Table A-5. Material content assumptions for selected metals and materials in batteries designated for cell phones, by year.

[Li, lithium; Li-ion, lithium-ion battery; Li-polymer, lithium-polymer battery; NiCd, nickel-cadmium battery; NiMH, nickel-metal-hydride battery. Estimates were derived from U.S. International Trade Commission data and material distribution data provided by Pillot (2004, p. 23; 2005a, p. 5; 2005b, p. 19). Values may not add to totals shown owing to rounding]

\begin{tabular}{|c|c|c|c|c|c|c|c|c|c|c|c|}
\hline Year & Cell chemistry & $\begin{array}{c}\text { Number of } \\
\text { units }\end{array}$ & $\begin{array}{c}\text { Cell mass, } \\
\text { grams per } \\
\text { battery }\end{array}$ & $\begin{array}{l}\text { Cadmium } \\
\text { fraction, in } \\
\text { percent }\end{array}$ & $\begin{array}{c}\text { Cobalt } \\
\text { fraction, in } \\
\text { percent }\end{array}$ & $\begin{array}{l}\text { Lithium } \\
\text { fraction, in } \\
\text { percent }\end{array}$ & $\begin{array}{c}\text { Nickel } \\
\text { fraction, in } \\
\text { percent }\end{array}$ & $\begin{array}{l}\text { Cadmium } \\
\text { mass, in } \\
\text { kilograms }\end{array}$ & $\begin{array}{c}\text { Cobalt } \\
\text { mass, in } \\
\text { kilograms }\end{array}$ & $\begin{array}{c}\text { Lithium } \\
\text { mass, in } \\
\text { kilograms }\end{array}$ & $\begin{array}{c}\text { Nickel } \\
\text { mass, in } \\
\text { kilograms }\end{array}$ \\
\hline \multirow[t]{4}{*}{1996} & $\mathrm{NiCd}$ & $1,800,000$ & 80 & 14 & 0.9 & 0 & 22 & 20,000 & 1,300 & 0 & 31,000 \\
\hline & $\mathrm{NiMH}$ & $1,900,000$ & 74 & 0 & 2.2 & 0 & 37 & 0 & 3,100 & 0 & 53,000 \\
\hline & Li-ion & $1,100,000$ & 72 & 0 & 17.6 & 2.3 & 0 & 0 & 14,000 & 1,800 & 0 \\
\hline & Li-polymer & 0 & 47 & 0 & 15.9 & 1.7 & 0 & 0 & 0 & 0 & 0 \\
\hline \multirow[t]{4}{*}{1997} & $\mathrm{NiCd}$ & $2,000,000$ & 80 & 14 & 0.9 & 0 & 22 & 22,000 & 1,400 & 0 & 34,000 \\
\hline & NiMH & $3,300,000$ & 74 & 0 & 2.2 & 0 & 37 & 0 & 5,300 & 0 & 89,000 \\
\hline & Li-ion & $2,900,000$ & 72 & 0 & 17.6 & 2.3 & 0 & 0 & 37,000 & 4,900 & 0 \\
\hline & Li-polymer & 0 & 47 & 0 & 15.9 & 1.7 & 0 & 0 & 0 & 0 & 0 \\
\hline \multirow[t]{4}{*}{1998} & $\mathrm{NiCd}$ & $1,700,000$ & 80 & 14 & 0.9 & 0 & 22 & 19,000 & 1,200 & 0 & 30,000 \\
\hline & $\mathrm{NiMH}$ & $6,500,000$ & 74 & 0 & 2.2 & 0 & 37 & 0 & 11,000 & 0 & 180,000 \\
\hline & Li-ion & $4,800,000$ & 72 & 0 & 17.6 & 2.3 & 0 & 0 & 61,000 & 8,000 & 0 \\
\hline & Li-polymer & 0 & 47 & 0 & 15.9 & 1.7 & 0 & 0 & 0 & 0 & 0 \\
\hline \multirow[t]{4}{*}{1999} & $\mathrm{NiCd}$ & $1,600,000$ & 80 & 14 & 0.9 & 0 & 22 & 18,000 & 1,200 & 0 & 29,000 \\
\hline & $\mathrm{NiMH}$ & $15,000,000$ & 74 & 0 & 2.2 & 0 & 37 & 0 & 24,000 & 0 & 400,000 \\
\hline & Li-ion & $10,000,000$ & 72 & 0 & 17.6 & 2.3 & 0 & 0 & 130,000 & 17,000 & 0 \\
\hline & Li-polymer & 270,000 & 47 & 0 & 15.9 & 1.7 & 0 & 0 & 2,000 & 220 & 0 \\
\hline \multirow[t]{4}{*}{2000} & $\mathrm{NiCd}$ & $1,000,000$ & 80 & 14 & 0.9 & 0 & 22 & 12,000 & 700 & 0 & 18,000 \\
\hline & $\mathrm{NiMH}$ & $30,000,000$ & 74 & 0 & 2.2 & 0 & 37 & 0 & 48,000 & 0 & 810,000 \\
\hline & Li-ion & $20,000,000$ & 72 & 0 & 17.6 & 2.3 & 0 & 0 & 260,000 & 33,000 & 0 \\
\hline & Li-polymer & $1,000,000$ & 47 & 0 & 15.9 & 1.7 & 0 & 0 & 7,700 & 830 & 0 \\
\hline \multirow[t]{4}{*}{2001} & $\mathrm{NiCd}$ & 0 & 80 & 14 & 0.9 & 0 & 22 & 0 & 0 & 0 & 0 \\
\hline & $\mathrm{NiMH}$ & $35,000,000$ & 42 & 0 & 2.2 & 0 & 37 & 0 & 32,000 & 0 & 540,000 \\
\hline & Li-ion & $39,000,000$ & 48 & 0 & 17.6 & 2.3 & 0 & 0 & 330,000 & 43,000 & 0 \\
\hline & Li-polymer & $3,100,000$ & 42 & 0 & 15.9 & 1.7 & 0 & 0 & 21,000 & 2,200 & 0 \\
\hline \multirow[t]{4}{*}{2002} & $\mathrm{NiCd}$ & 0 & 80 & 14 & 0.9 & 0 & 22 & 0 & 0 & 0 & 0 \\
\hline & $\mathrm{NiMH}$ & $29,000,000$ & 42 & 0 & 2.2 & 0 & 37 & 0 & 27,000 & 0 & 450,000 \\
\hline & Li-ion & $52,000,000$ & 48 & 0 & 17.6 & 2.3 & 0 & 0 & 440,000 & 58,000 & 0 \\
\hline & Li-polymer & $6,100,000$ & 42 & 0 & 15.9 & 1.7 & 0 & 0 & 41,000 & 4,400 & 0 \\
\hline \multirow[t]{4}{*}{2003} & $\mathrm{NiCd}$ & 0 & 80 & 14 & 0.9 & 0 & 22 & 0 & 0 & 0 & 0 \\
\hline & $\mathrm{NiMH}$ & $15,000,000$ & 42 & 0 & 2.2 & 0 & 37 & 0 & 14,000 & 0 & 230,000 \\
\hline & Li-ion & $75,000,000$ & 48 & 0 & 17.6 & 2.3 & 0 & 0 & 630,000 & 83,000 & 0 \\
\hline & Li-polymer & $12,000,000$ & 42 & 0 & 15.9 & 1.7 & 0 & 0 & 83,000 & 8,800 & 0 \\
\hline \multirow[t]{4}{*}{2004} & $\mathrm{NiCd}$ & 0 & 80 & 14 & 0.9 & 0 & 22 & 0 & 0 & 0 & 0 \\
\hline & NiMH & $8,800,000$ & 42 & 0 & 2.2 & 0 & 37 & 0 & 8,100 & 0 & 140,000 \\
\hline & Li-ion & $120,000,000$ & 48 & 0 & 17.6 & 2.3 & 0 & 0 & 990,000 & 130,000 & 0 \\
\hline & Li-polymer & $20,000,000$ & 42 & 0 & 15.9 & 1.7 & 0 & 0 & 140,000 & 15,000 & 0 \\
\hline \multirow[t]{4}{*}{2005} & $\mathrm{NiCd}$ & 0 & 80 & 14 & 0.9 & 0 & 22 & 0 & 0 & 0 & 0 \\
\hline & $\mathrm{NiMH}$ & $7,000,000$ & 42 & 0 & 2.2 & 0 & 37 & 0 & 6,400 & 0 & 110,000 \\
\hline & Li-ion & $140,000,000$ & 48 & 0 & 17.6 & 2.3 & 0 & 0 & $1,200,000$ & 150,000 & 0 \\
\hline & Li-polymer & $30,000,000$ & 42 & 0 & 15.9 & 1.7 & 0 & 0 & 200,000 & 21,000 & 0 \\
\hline
\end{tabular}


Table A-6. Material content assumptions for selected metals and materials in batteries designated for portable (laptop) computers, by year.

[Li-ion, lithium-ion battery; NiMH, nickel-metal-hydride battery. Estimates were derived from U.S. International Trade Commission data and material distribution data provided by Pillot (2004, p. 29; 2005a, p. 6 ). Values may not add to totals shown owing to rounding]

\begin{tabular}{|c|c|c|c|c|c|c|c|c|}
\hline Year & $\begin{array}{c}\text { Cell } \\
\text { chemistry }\end{array}$ & $\begin{array}{c}\text { Number of } \\
\text { units }\end{array}$ & $\begin{array}{c}\text { Cobalt } \\
\text { mass, in } \\
\text { grams per } \\
\text { battery } \\
\text { pack }\end{array}$ & $\begin{array}{c}\text { Lithium } \\
\text { mass, in } \\
\text { grams per } \\
\text { battery } \\
\text { pack }\end{array}$ & $\begin{array}{c}\text { Nickel } \\
\text { mass, in } \\
\text { grams per } \\
\text { battery } \\
\text { pack }\end{array}$ & $\begin{array}{c}\text { Cobalt } \\
\text { mass, in } \\
\text { kilograms }\end{array}$ & $\begin{array}{c}\text { Lithium } \\
\text { mass, in } \\
\text { kilograms }\end{array}$ & $\begin{array}{c}\text { Nickel } \\
\text { mass, in } \\
\text { kilograms }\end{array}$ \\
\hline \multicolumn{9}{|c|}{ U.S. import data } \\
\hline \multirow[t]{2}{*}{1996} & NiMH & $1,000,000$ & 5 & 0 & 85 & 5,100 & 0 & 86,000 \\
\hline & Li-ion & 830,000 & 46 & 5.2 & 0 & 36,000 & 4,300 & 0 \\
\hline \multirow[t]{2}{*}{1997} & NiMH & $1,200,000$ & 5 & 0 & 85 & 6,300 & 0 & 110,000 \\
\hline & Li-ion & $1,700,000$ & 46 & 5.2 & 0 & 75,000 & 8,900 & 0 \\
\hline \multirow[t]{2}{*}{1998} & $\mathrm{NiMH}$ & $1,200,000$ & 5 & 0 & 85 & 5,900 & 0 & 99,000 \\
\hline & Li-ion & $2,300,000$ & 46 & 5.2 & 0 & 99,000 & 12,000 & 0 \\
\hline \multirow[t]{2}{*}{1999} & $\mathrm{NiMH}$ & $1,300,000$ & 5 & 0 & 85 & 6,500 & 0 & 110,000 \\
\hline & Li-ion & $3,500,000$ & 46 & 5.2 & 0 & 150,000 & 18,000 & 0 \\
\hline \multirow[t]{2}{*}{2000} & $\mathrm{NiMH}$ & $1,900,000$ & 5 & 0 & 85 & 9,700 & 0 & 160,000 \\
\hline & Li-ion & $6,400,000$ & 46 & 5.2 & 0 & 280,000 & 33,000 & 0 \\
\hline \multirow[t]{2}{*}{2001} & $\mathrm{NiMH}$ & $1,900,000$ & 5 & 0 & 85 & 9,800 & 0 & 160,000 \\
\hline & Li-ion & $8,300,000$ & 46 & 5.2 & 0 & 360,000 & 43,000 & 0 \\
\hline \multirow[t]{2}{*}{2002} & $\mathrm{NiMH}$ & $2,400,000$ & 5 & 0 & 85 & 12,000 & 0 & 200,000 \\
\hline & Li-ion & $13,000,000$ & 46 & 5.2 & 0 & 550,000 & 66,000 & 0 \\
\hline \multirow[t]{2}{*}{2003} & NiMH & $1,800,000$ & 5 & 0 & 85 & 8,900 & 0 & 150,000 \\
\hline & Li-ion & $17,000,000$ & 46 & 5.2 & 0 & 740,000 & 88,000 & 0 \\
\hline \multirow[t]{2}{*}{2004} & $\mathrm{NiMH}$ & $1,900,000$ & 5 & 0 & 85 & 9,500 & 0 & 160,000 \\
\hline & Li-ion & $18,000,000$ & 46 & 5.2 & 0 & 790,000 & 94,000 & 0 \\
\hline \multirow[t]{2}{*}{2005} & $\mathrm{NiMH}$ & $1,900,000$ & 5 & 0 & 85 & 9,600 & 0 & 160,000 \\
\hline & Li-ion & $22,000,000$ & 46 & 5.2 & 0 & 960,000 & 110,000 & 0 \\
\hline \multicolumn{9}{|c|}{ U.S. export data } \\
\hline \multirow[t]{2}{*}{1996} & NiMH & 230,000 & 5 & 0 & 85 & 1,100 & 0 & 19,000 \\
\hline & Li-ion & 190,000 & 46 & 5.2 & 0 & 8,100 & 1,000 & 0 \\
\hline \multirow[t]{2}{*}{1997} & $\mathrm{NiMH}$ & 250,000 & 5 & 0 & 85 & 1,300 & 0 & 21,000 \\
\hline & Li-ion & 350,000 & 46 & 5.2 & 0 & 15,000 & 1,800 & 0 \\
\hline \multirow[t]{2}{*}{1998} & NiMH & 230,000 & 5 & 0 & 85 & 1,200 & 0 & 19,000 \\
\hline & Li-ion & 440,000 & 46 & 5.2 & 0 & 19,000 & 2,300 & 0 \\
\hline \multirow[t]{2}{*}{1999} & NiMH & 200,000 & 5 & 0 & 85 & 1,000 & 0 & 17,000 \\
\hline & Li-ion & 540,000 & 46 & 5.2 & 0 & 24,000 & 2,800 & 0 \\
\hline \multirow[t]{2}{*}{2000} & $\mathrm{NiMH}$ & 230,000 & 5 & 0 & 85 & 1,200 & 0 & 19,000 \\
\hline & Li-ion & 770,000 & 46 & 5.2 & 0 & 34,000 & 4,000 & 0 \\
\hline \multirow[t]{2}{*}{2001} & $\mathrm{NiMH}$ & 210,000 & 5 & 0 & 85 & 1,100 & 0 & 18,000 \\
\hline & Li-ion & 910,000 & 46 & 5.2 & 0 & 40,000 & 4,800 & 0 \\
\hline \multirow[t]{2}{*}{2002} & NiMH & 200,000 & 5 & 0 & 85 & 1,000 & 0 & 17,000 \\
\hline & Li-ion & $1,000,000$ & 46 & 5.2 & 0 & 46,000 & 5,500 & 0 \\
\hline \multirow[t]{2}{*}{2003} & $\mathrm{NiMH}$ & 150,000 & 5 & 0 & 85 & 700 & 0 & 13,000 \\
\hline & Li-ion & $1,400,000$ & 46 & 5.2 & 0 & 61,000 & 7,300 & 0 \\
\hline \multirow[t]{2}{*}{2004} & $\mathrm{NiMH}$ & 350,000 & 5 & 0 & 85 & 1,700 & 0 & 29,000 \\
\hline & Li-ion & $3,300,000$ & 46 & 5.2 & 0 & 140,000 & 17,000 & 0 \\
\hline \multirow[t]{2}{*}{2005} & $\mathrm{NiMH}$ & 260,000 & 5 & 0 & 85 & 1,300 & 0 & 22,000 \\
\hline & Li-ion & $3,000,000$ & 46 & 5.2 & 0 & 130,000 & 15,000 & 0 \\
\hline
\end{tabular}


Table A-6. Material content assumptions for selected metals and materials in batteries designated for portable (laptop) computers, by year.-Continued

[Li-ion, lithium-ion battery; NiMH, nickel-metal-hydride battery. Estimates were derived from U.S. International Trade Commission data and material distribution data provided by Pillot (2004, p. 29; 2005a, p. 6 ). Values may not add to totals shown owing to rounding]

\begin{tabular}{|c|c|c|c|c|c|c|c|c|}
\hline Year & $\begin{array}{c}\text { Cell } \\
\text { chemistry }\end{array}$ & $\begin{array}{c}\text { Number of } \\
\text { units }\end{array}$ & $\begin{array}{c}\text { Cobalt } \\
\text { mass, in } \\
\text { grams per } \\
\text { battery } \\
\text { pack }\end{array}$ & $\begin{array}{l}\text { Lithium } \\
\text { mass, in } \\
\text { grams per } \\
\text { battery } \\
\text { pack }\end{array}$ & $\begin{array}{c}\text { Nickel } \\
\text { mass, in } \\
\text { grams per } \\
\text { battery } \\
\text { pack }\end{array}$ & $\begin{array}{c}\text { Cobalt } \\
\text { mass, in } \\
\text { kilograms }\end{array}$ & $\begin{array}{c}\text { Lithium } \\
\text { mass, in } \\
\text { kilograms }\end{array}$ & $\begin{array}{c}\text { Nickel } \\
\text { mass, in } \\
\text { kilograms }\end{array}$ \\
\hline \multicolumn{9}{|c|}{ Net import data } \\
\hline \multirow[t]{2}{*}{1996} & NiMH & 770,000 & 5 & 0 & 85 & 4,000 & 0 & 67,000 \\
\hline & Li-ion & 640,000 & 46 & 5.2 & 0 & 28,000 & 3,300 & 0 \\
\hline \multirow[t]{2}{*}{1997} & $\mathrm{NiMH}$ & 990,000 & 5 & 0 & 85 & 5,000 & 0 & 84,000 \\
\hline & Li-ion & $1,400,000$ & 46 & 5.2 & 0 & 60,000 & 7,100 & 0 \\
\hline \multirow[t]{2}{*}{1998} & NiMH & 940,000 & 5 & 0 & 85 & 4,700 & 0 & 79,000 \\
\hline & Li-ion & $1,800,000$ & 46 & 5.2 & 0 & 79,000 & 9,500 & 0 \\
\hline \multirow[t]{2}{*}{1999} & NiMH & $1,100,000$ & 5 & 0 & 85 & 5,500 & 0 & 92,000 \\
\hline & Li-ion & $2,900,000$ & 46 & 5.2 & 0 & 130,000 & 15,000 & 0 \\
\hline \multirow[t]{2}{*}{2000} & $\mathrm{NiMH}$ & $1,700,000$ & 5 & 0 & 85 & 8,500 & 0 & 140,000 \\
\hline & Li-ion & $5,600,000$ & 46 & 5.2 & 0 & 250,000 & 29,000 & 0 \\
\hline \multirow[t]{2}{*}{2001} & $\mathrm{NiMH}$ & $1,700,000$ & 5 & 0 & 85 & 8,700 & 0 & 150,000 \\
\hline & Li-ion & $7,400,000$ & 46 & 5.2 & 0 & 320,000 & 38,000 & 0 \\
\hline \multirow[t]{2}{*}{2002} & $\mathrm{NiMH}$ & $2,200,000$ & 5 & 0 & 85 & 11,000 & 0 & 190,000 \\
\hline & Li-ion & $12,000,000$ & 46 & 5.2 & 0 & 510,000 & 60,000 & 0 \\
\hline \multirow[t]{2}{*}{2003} & NiMH & $1,600,000$ & 5 & 0 & 85 & 8,200 & 0 & 140,000 \\
\hline & Li-ion & $15,000,000$ & 46 & 5.2 & 0 & 680,000 & 81,000 & 0 \\
\hline \multirow[t]{2}{*}{2004} & NiMH & $1,500,000$ & 5 & 0 & 85 & 7,800 & 0 & 130,000 \\
\hline & Li-ion & $15,000,000$ & 46 & 5.2 & 0 & 640,000 & 77,000 & 0 \\
\hline \multirow[t]{2}{*}{2005} & $\mathrm{NiMH}$ & $1,600,000$ & 5 & 0 & 85 & 8,300 & 0 & 140,000 \\
\hline & Li-ion & $19,000,000$ & 46 & 5.2 & 0 & 830,000 & 99,000 & 0 \\
\hline
\end{tabular}


Table A-7. Material content assumptions for selected metals and materials in batteries designated for cameras, by year.

[Li-ion, lithium-ion battery; NA, not available; XX, not applicable; NiCd, nickel-cadmium battery; NiMH, nickel-metal-hydride battery; Primary Li, primary lithium battery. Estimates were derived from U.S. International Trade Commission data and material distribution data provided by Pillot $(2004$, p. 27, 30; 2005a, p. 7). Number of units reflects the number of net camera imports to the United States. Net export situations are represented by a 0 value. Domestic camera battery production is assumed negligible. Values may not add to totals shown owing to rounding]

\begin{tabular}{|c|c|c|c|c|c|c|c|c|c|c|}
\hline Year & $\begin{array}{c}\text { Cell } \\
\text { chemistry/ } \\
\text { product type }\end{array}$ & $\begin{array}{c}\text { Number of } \\
\text { units }\end{array}$ & $\begin{array}{l}\text { Cadmium } \\
\text { mass, in } \\
\text { grams per } \\
\text { pack }\end{array}$ & $\begin{array}{c}\text { Cobalt } \\
\text { mass, in } \\
\text { grams per } \\
\text { pack }\end{array}$ & $\begin{array}{l}\text { Lithium } \\
\text { mass, in } \\
\text { grams per } \\
\text { pack }\end{array}$ & $\begin{array}{c}\text { Nickel } \\
\text { mass, in } \\
\text { grams per } \\
\text { pack }\end{array}$ & $\begin{array}{c}\text { Cadmium } \\
\text { mass, in } \\
\text { kilograms }\end{array}$ & $\begin{array}{c}\text { Cobalt } \\
\text { mass, in } \\
\text { kilograms }\end{array}$ & $\begin{array}{c}\text { Lithium } \\
\text { mass, in } \\
\text { kilograms }\end{array}$ & $\begin{array}{c}\text { Nickel } \\
\text { mass, in } \\
\text { kilograms }\end{array}$ \\
\hline \multirow[t]{12}{*}{1996} & $\mathrm{NiCd}$ & 61,000 & 19 & 0.5 & 0 & 29 & 1,200 & 31 & $\overline{X X}$ & $\overline{1,800}$ \\
\hline & Analog & 61,000 & 19 & NA & 0 & 29 & 1,200 & NA & XX & 1,800 \\
\hline & Digital & 0 & 0 & NA & 0 & 0 & 0 & NA & $\mathrm{XX}$ & 0 \\
\hline & NiMH & 0 & 0 & NA & 0 & NA & XX & 0 & $\mathrm{XX}$ & 0 \\
\hline & Analog & 0 & 0 & 1.1 & 0 & 19 & XX & 0 & XX & 0 \\
\hline & Digital & 0 & 0 & 0.3 & 0 & 5.2 & XX & 0 & XX & 0 \\
\hline & Li-ion & 0 & 0 & NA & NA & 0 & XX & 0 & 0 & $\mathrm{XX}$ \\
\hline & Analog & 0 & 0 & 9 & 1.1 & 0 & XX & 0 & 0 & XX \\
\hline & Digital & 0 & 0 & 2.4 & 0.72 & 0 & XX & 0 & 0 & XX \\
\hline & Primary Li & 550,000 & 0 & 0 & 1.3 & 0 & XX & 0 & 110 & $\mathrm{XX}$ \\
\hline & Analog & 550,000 & 0 & 0 & 1.3 & 0 & XX & 0 & 110 & $\mathrm{XX}$ \\
\hline & Digital & 0 & 0 & 0 & 1.3 & 0 & XX & 0 & 0 & $\mathrm{XX}$ \\
\hline \multirow[t]{12}{*}{1997} & $\mathrm{NiCd}$ & 58,000 & 19 & 0.5 & 0 & 29 & 1,100 & 29 & $\mathrm{XX}$ & 1,700 \\
\hline & Analog & 32,000 & 19 & NA & 0 & 29 & 620 & NA & $\mathrm{XX}$ & 950 \\
\hline & Digital & 26,000 & 0 & NA & 0 & 0 & 480 & NA & $\mathrm{XX}$ & 750 \\
\hline & NiMH & 58,000 & 0 & NA & 0 & NA & XX & 41 & $\mathrm{XX}$ & 700 \\
\hline & Analog & 32,000 & 0 & 1.1 & 0 & 19 & XX & NA & $\mathrm{XX}$ & 580 \\
\hline & Digital & 26,000 & 0 & 0.3 & 0 & 5.2 & XX & NA & $\mathrm{XX}$ & 120 \\
\hline & Li-ion & 58,000 & 0 & NA & NA & 0 & XX & 330 & 54 & $\mathrm{XX}$ \\
\hline & Analog & 32,000 & 0 & 9 & 1.1 & 0 & XX & NA & 36 & XX \\
\hline & Digital & 26,000 & 0 & 2.4 & 0.72 & 0 & XX & NA & 18 & $\mathrm{XX}$ \\
\hline & Primary Li & 990,000 & 0 & 0 & 1.3 & 0 & XX & 0 & 220 & $\mathrm{XX}$ \\
\hline & Analog & 550,000 & 0 & 0 & 1.3 & 0 & XX & 0 & 120 & $\mathrm{XX}$ \\
\hline & Digital & 440,000 & 0 & 0 & 1.3 & 0 & XX & 0 & 100 & XX \\
\hline \multirow[t]{12}{*}{1998} & $\mathrm{NiCd}$ & 100,000 & 19 & 0.5 & 0 & 29 & 2,000 & 52 & $\mathrm{XX}$ & 3,000 \\
\hline & Analog & 28,000 & 19 & NA & 0 & 29 & 530 & NA & XX & 820 \\
\hline & Digital & 75,000 & 0 & NA & 0 & 0 & 1,400 & NA & $\mathrm{XX}$ & 2,200 \\
\hline & NiMH & 160,000 & 0 & NA & 0 & NA & XX & 76 & $\mathrm{XX}$ & 1,300 \\
\hline & Analog & 45,000 & 0 & 1.1 & 0 & 19 & XX & NA & $\mathrm{XX}$ & 740 \\
\hline & Digital & 120,000 & 0 & 0.3 & 0 & 5.2 & XX & NA & $\mathrm{XX}$ & 530 \\
\hline & Li-ion & 210,000 & 0 & NA & NA & 0 & XX & 750 & 170 & XX \\
\hline & Analog & 56,000 & 0 & 9 & 1.1 & 0 & XX & NA & 50 & $\mathrm{XX}$ \\
\hline & Digital & 150,000 & 0 & 2.4 & 0.72 & 0 & XX & NA & 120 & XX \\
\hline & Primary Li & $1,600,000$ & 0 & 0 & 1.3 & 0 & XX & 0 & 370 & $\mathrm{XX}$ \\
\hline & Analog & 430,000 & 0 & 0 & 1.3 & 0 & XX & 0 & 100 & $\mathrm{XX}$ \\
\hline & Digital & $1,200,000$ & 0 & 0 & 1.3 & 0 & XX & 0 & 270 & XX \\
\hline \multirow[t]{12}{*}{1999} & $\mathrm{NiCd}$ & 120,000 & 19 & 0.5 & 0 & 29 & 2,300 & 61 & $\mathrm{XX}$ & 3,500 \\
\hline & Analog & 25,000 & 19 & NA & 0 & 29 & 480 & NA & $\mathrm{XX}$ & 730 \\
\hline & Digital & 95,000 & 0 & NA & 0 & 0 & 1,800 & NA & $\mathrm{XX}$ & 2,700 \\
\hline & NiMH & 600,000 & 0 & NA & 0 & NA & XX & 270 & $\mathrm{XX}$ & 4,600 \\
\hline & Analog & 130,000 & 0 & 1.1 & 0 & 19 & XX & NA & $\mathrm{XX}$ & 1,000 \\
\hline & Digital & 470,000 & 0 & 0.3 & 0 & 5.2 & XX & NA & $\mathrm{XX}$ & 3,600 \\
\hline & $\mathrm{Li}$-ion & 720,000 & 0 & NA & NA & 0 & XX & 2,600 & 580 & XX \\
\hline & Analog & 150,000 & 0 & 9 & 1.1 & 0 & XX & NA & 120 & $\mathrm{XX}$ \\
\hline & Digital & 570,000 & 0 & 2.4 & 0.72 & 0 & XX & NA & 460 & XX \\
\hline & Primary $\mathrm{Li}$ & $4,500,000$ & 0 & 0 & 1.3 & 0 & XX & 0 & 1,100 & $\mathrm{XX}$ \\
\hline & Analog & 950,000 & 0 & 0 & 1.3 & 0 & XX & 0 & 230 & XX \\
\hline & Digital & $3,600,000$ & 0 & 0 & 1.3 & 0 & XX & 0 & 870 & XX \\
\hline
\end{tabular}


Table A-7. Material content assumptions for selected metals and materials in batteries designated for cameras, by year.-Continued [Li-ion, lithium-ion battery; NA, not available; XX, not applicable; NiCd, nickel-cadmium battery; NiMH, nickel-metal-hydride battery; Primary Li, primary lithium battery. Estimates were derived from U.S. International Trade Commission data and material distribution data provided by Pillot (2004, p. 27, 30; 2005a, p. 7). Number of units reflects the number of net camera imports to the United States. Net export situations are represented by a 0 value. Domestic camera battery production is assumed negligible. Values may not add to totals shown owing to rounding]

\begin{tabular}{|c|c|c|c|c|c|c|c|c|c|c|}
\hline Year & $\begin{array}{c}\text { Cell } \\
\text { chemistry/ } \\
\text { product type }\end{array}$ & $\begin{array}{c}\text { Number of } \\
\text { units }\end{array}$ & $\begin{array}{c}\text { Cadmium } \\
\text { mass, in } \\
\text { grams per } \\
\text { pack }\end{array}$ & $\begin{array}{c}\text { Cobalt } \\
\text { mass, in } \\
\text { grams per } \\
\text { pack }\end{array}$ & $\begin{array}{c}\text { Lithium } \\
\text { mass, in } \\
\text { grams per } \\
\text { pack }\end{array}$ & $\begin{array}{c}\text { Nickel } \\
\text { mass, in } \\
\text { grams per } \\
\text { pack }\end{array}$ & $\begin{array}{l}\text { Cadmium } \\
\text { mass, in } \\
\text { kilograms }\end{array}$ & $\begin{array}{c}\text { Cobalt } \\
\text { mass, in } \\
\text { kilograms }\end{array}$ & $\begin{array}{l}\text { Lithium } \\
\text { mass, in } \\
\text { kilograms }\end{array}$ & $\begin{array}{c}\text { Nickel } \\
\text { mass, in } \\
\text { kilograms }\end{array}$ \\
\hline \multirow[t]{12}{*}{2000} & $\mathrm{NiCd}$ & 0 & 19 & 0.5 & 0 & 29 & 0 & 0 & $\mathrm{XX}$ & 0 \\
\hline & Analog & 0 & 19 & NA & 0 & 29 & 0 & 0 & XX & 0 \\
\hline & Digital & 0 & 0 & NA & 0 & 0 & 0 & 0 & XX & 0 \\
\hline & NiMH & $1,800,000$ & 0 & NA & 0 & NA & XX & 740 & $X X$ & 12,000 \\
\hline & Analog & 250,000 & 0 & 1.1 & 0 & 19 & XX & NA & XX & 4,600 \\
\hline & Digital & $1,600,000$ & 0 & 0.3 & 0 & 5.2 & XX & NA & $\mathrm{XX}$ & 7,800 \\
\hline & Li-ion & $2,400,000$ & 0 & NA & NA & 0 & $\mathrm{XX}$ & 7,900 & 1,800 & XX \\
\hline & Analog & 340,000 & 0 & 9 & 1.1 & 0 & $\mathrm{XX}$ & NA & 250 & $\mathrm{XX}$ \\
\hline & Digital & $2,100,000$ & 0 & 2.4 & 0.72 & 0 & XX & NA & 1,500 & XX \\
\hline & Primary Li & $7,900,000$ & 0 & 0 & 1.3 & 0 & $\mathrm{XX}$ & 0 & 2,200 & XX \\
\hline & Analog & $1,100,000$ & 0 & 0 & 1.3 & 0 & XX & 0 & 310 & $\mathrm{XX}$ \\
\hline & Digital & $6,800,000$ & 0 & 0 & 1.3 & 0 & XX & 0 & 1,900 & XX \\
\hline \multirow[t]{12}{*}{2001} & $\mathrm{NiCd}$ & 0 & 19 & 0.5 & 0 & 29 & 0 & 0 & XX & 0 \\
\hline & Analog & 0 & 19 & NA & 0 & 29 & 0 & 0 & XX & 0 \\
\hline & Digital & 0 & 0 & NA & 0 & 0 & 0 & 0 & XX & 0 \\
\hline & NiMH & $1,500,000$ & 0 & NA & 0 & NA & XX & 580 & XX & 9,700 \\
\hline & Analog & 150,000 & 0 & 1.1 & 0 & 19 & XX & NA & XX & 2,800 \\
\hline & Digital & $1,400,000$ & 0 & 0.3 & 0 & 5.2 & XX & NA & XX & 6,900 \\
\hline & Li-ion & $3,100,000$ & 0 & NA & NA & 0 & XX & 9,200 & 2,300 & XX \\
\hline & Analog & 310,000 & 0 & 9 & 1.1 & 0 & $\mathrm{XX}$ & NA & 230 & XX \\
\hline & Digital & $2,800,000$ & 0 & 2.4 & 0.72 & 0 & $\mathrm{XX}$ & NA & 2,100 & XX \\
\hline & Primary Li & $5,700,000$ & 0 & 0 & 1.3 & 0 & $\mathrm{XX}$ & 0 & 1,600 & XX \\
\hline & Analog & 570,000 & 0 & 0 & 1.3 & 0 & $\mathrm{XX}$ & 0 & 160 & XX \\
\hline & Digital & $5,100,000$ & 0 & 0 & 1.3 & 0 & $\mathrm{XX}$ & 0 & 1,500 & XX \\
\hline \multirow[t]{12}{*}{2002} & $\mathrm{NiCd}$ & 0 & 19 & 0.5 & 0 & 29 & 0 & 0 & XX & 0 \\
\hline & Analog & 0 & 19 & NA & 0 & 29 & 0 & 0 & XX & 0 \\
\hline & Digital & 0 & 0 & NA & 0 & 0 & 0 & 0 & XX & 0 \\
\hline & NiMH & $2,100,000$ & 0 & NA & 0 & NA & XX & 690 & XX & 12,000 \\
\hline & Analog & 100,000 & 0 & 1.1 & 0 & 19 & XX & NA & XX & 1,800 \\
\hline & Digital & $1,900,000$ & 0 & 0.3 & 0 & 5.2 & XX & NA & XX & 9,700 \\
\hline & Li-ion & $5,500,000$ & 0 & NA & NA & 0 & XX & 15,000 & 4,100 & XX \\
\hline & Analog & 280,000 & 0 & 9 & 1.1 & 0 & XX & NA & 200 & XX \\
\hline & Digital & $5,200,000$ & 0 & 2.4 & 0.72 & 0 & XX & NA & 3,900 & XX \\
\hline & Primary Li & $8,200,000$ & 0 & 0 & 1.3 & 0 & $\mathrm{XX}$ & 0 & 2,400 & XX \\
\hline & Analog & 410,000 & 0 & 0 & 1.3 & 0 & $\mathrm{XX}$ & 0 & 120 & XX \\
\hline & Digital & $7,800,000$ & 0 & 0 & 1.3 & 0 & $\mathrm{XX}$ & 0 & 2,300 & XX \\
\hline \multirow[t]{12}{*}{2003} & $\mathrm{NiCd}$ & 0 & 19 & 0.5 & 0 & 29 & 0 & 0 & XX & 0 \\
\hline & Analog & 0 & 19 & NA & 0 & 29 & 0 & 0 & XX & 0 \\
\hline & Digital & 0 & 0 & NA & 0 & 0 & 0 & 0 & XX & 0 \\
\hline & NiMH & $2,200,000$ & 0 & NA & 0 & NA & XX & 780 & XX & 13,000 \\
\hline & Analog & 130,000 & 0 & 1.1 & 0 & 19 & XX & NA & XX & 900 \\
\hline & Digital & $2,100,000$ & 0 & 0.3 & 0 & 5.2 & $\mathrm{XX}$ & NA & XX & 12,000 \\
\hline & Li-ion & $11,000,000$ & 0 & NA & NA & 0 & $\mathrm{XX}$ & 30,000 & 8,000 & $\mathrm{XX}$ \\
\hline & Analog & 640,000 & 0 & 9 & 1.1 & 0 & XX & NA & 480 & XX \\
\hline & Digital & $10,000,000$ & 0 & 2.4 & 0.72 & 0 & XX & NA & 7,500 & XX \\
\hline & Primary Li & $12,000,000$ & 0 & 0 & 1.3 & 0 & XX & 0 & 3,800 & XX \\
\hline & Analog & 720,000 & 0 & 0 & 1.3 & 0 & XX & 0 & 230 & XX \\
\hline & Digital & $11,000,000$ & 0 & 0 & 1.3 & 0 & XX & 0 & 3,600 & XX \\
\hline
\end{tabular}


Table A-7. Material content assumptions for selected metals and materials in batteries designated for cameras, by year.—Continued

[Li-ion, lithium-ion battery; NA, not available; XX, not applicable; NiCd, nickel-cadmium battery; NiMH, nickel-metal-hydride battery; Primary Li, primary lithium battery. Estimates were derived from U.S. International Trade Commission data and material distribution data provided by Pillot (2004, p. 27, 30; 2005a, p. 7). Number of units reflects the number of net camera imports to the United States. Net export situations are represented by a 0 value. Domestic camera battery production is assumed negligible. Values may not add to totals shown owing to rounding]

\begin{tabular}{|c|c|c|c|c|c|c|c|c|c|c|}
\hline Year & $\begin{array}{c}\text { Cell } \\
\text { chemistry/ } \\
\text { product type }\end{array}$ & $\begin{array}{c}\text { Number of } \\
\text { units }\end{array}$ & $\begin{array}{c}\text { Cadmium } \\
\text { mass, in } \\
\text { grams per } \\
\text { pack }\end{array}$ & $\begin{array}{c}\text { Cobalt } \\
\text { mass, in } \\
\text { grams per } \\
\text { pack }\end{array}$ & $\begin{array}{c}\text { Lithium } \\
\text { mass, in } \\
\text { grams per } \\
\text { pack }\end{array}$ & $\begin{array}{c}\text { Nickel } \\
\text { mass, in } \\
\text { grams per } \\
\text { pack }\end{array}$ & $\begin{array}{l}\text { Cadmium } \\
\text { mass, in } \\
\text { kilograms }\end{array}$ & $\begin{array}{c}\text { Cobalt } \\
\text { mass, in } \\
\text { kilograms }\end{array}$ & $\begin{array}{c}\text { Lithium } \\
\text { mass, in } \\
\text { kilograms }\end{array}$ & $\begin{array}{c}\text { Nickel } \\
\text { mass, in } \\
\text { kilograms }\end{array}$ \\
\hline \multirow[t]{12}{*}{2004} & $\mathrm{NiCd}$ & 0 & 19 & 0.5 & 0 & 29 & 0 & 0 & $\mathrm{XX}$ & 0 \\
\hline & Analog & 0 & 19 & NA & 0 & 29 & 0 & 0 & $\mathrm{XX}$ & 0 \\
\hline & Digital & 0 & 0 & NA & 0 & 0 & 0 & 0 & XX & 0 \\
\hline & $\mathrm{NiMH}$ & $2,400,000$ & 0 & NA & 0 & NA & $\mathrm{XX}$ & 780 & XX & 13,000 \\
\hline & Analog & 100,000 & 0 & 1.1 & 0 & 19 & $\mathrm{XX}$ & NA & XX & 1,900 \\
\hline & Digital & $2,300,000$ & 0 & 0.3 & 0 & 5.2 & XX & NA & XX & 11,000 \\
\hline & Li-ion & $14,000,000$ & 0 & NA & NA & 0 & XX & 36,000 & 11,000 & XX \\
\hline & Analog & 560,000 & 0 & 9 & 1.1 & 0 & $\mathrm{XX}$ & NA & 720 & XX \\
\hline & Digital & $13,000,000$ & 0 & 2.4 & 0.72 & 0 & XX & NA & 10,000 & XX \\
\hline & Primary Li & $14,000,000$ & 0 & 0 & 1.3 & 0 & XX & 0 & 3,900 & $\mathrm{XX}$ \\
\hline & Analog & 540,000 & 0 & 0 & 1.3 & 0 & $\mathrm{XX}$ & 0 & 160 & XX \\
\hline & Digital & $13,000,000$ & 0 & 0 & 1.3 & 0 & XX & 0 & 3,700 & XX \\
\hline \multirow[t]{12}{*}{2005} & $\mathrm{NiCd}$ & 0 & 19 & 0.5 & 0 & 29 & 0 & 0 & XX & 0 \\
\hline & Analog & 0 & 19 & NA & 0 & 29 & 0 & 0 & XX & 0 \\
\hline & Digital & 0 & 0 & NA & 0 & 0 & 0 & 0 & XX & 0 \\
\hline & NiMH & $1,800,000$ & 0 & NA & 0 & NA & XX & 600 & $\mathrm{XX}$ & 10,000 \\
\hline & Analog & 83,000 & 0 & 1.1 & 0 & 19 & $\mathrm{XX}$ & NA & XX & 1,500 \\
\hline & Digital & $1,800,000$ & 0 & 0.3 & 0 & 5.2 & XX & NA & XX & 9,500 \\
\hline & Li-ion & $19,000,000$ & 0 & NA & NA & 0 & $\mathrm{XX}$ & 49,000 & 14,000 & XX \\
\hline & Analog & 840,000 & 0 & 9 & 1.1 & 0 & $\mathrm{XX}$ & NA & 570 & XX \\
\hline & Digital & $18,000,000$ & 0 & 2.4 & 0.72 & 0 & $\mathrm{XX}$ & NA & 13,000 & XX \\
\hline & Primary Li & $16,000,000$ & 0 & 0 & 1.3 & 0 & XX & 0 & 5,400 & XX \\
\hline & Analog & 730,000 & 0 & 0 & 1.3 & 0 & XX & 0 & 260 & XX \\
\hline & Digital & $15,000,000$ & 0 & 0 & 1.3 & 0 & $\mathrm{XX}$ & 0 & 5,100 & $\mathrm{XX}$ \\
\hline
\end{tabular}


Table A-8. Material content assumptions for selected metals and materials in batteries designated for video cameras (camcorders), by year.

[Li-ion, lithium-ion battery; NA, Not available; XX, Not applicable; NiCd, nickel-cadmium battery; NiMH, nickel-metal-hydride battery. Estimates were derived from U.S. International Trade Commission data and material distribution data provided by Pillot (2004, p. 27, 30 ). Values may not add to totals shown owing to rounding]

\begin{tabular}{|c|c|c|c|c|c|c|c|c|c|c|}
\hline Year & Cell type & $\begin{array}{c}\text { Number of } \\
\text { units }\end{array}$ & $\begin{array}{l}\text { Cadmium } \\
\text { mass, in } \\
\text { grams per } \\
\text { pack }\end{array}$ & $\begin{array}{c}\text { Cobalt } \\
\text { mass, in } \\
\text { grams per } \\
\text { pack }\end{array}$ & $\begin{array}{l}\text { Lithium } \\
\text { mass, in } \\
\text { grams per } \\
\text { pack }\end{array}$ & $\begin{array}{c}\text { Nickel } \\
\text { mass, in } \\
\text { grams per } \\
\text { pack }\end{array}$ & $\begin{array}{l}\text { Cadmium } \\
\text { mass, in } \\
\text { kilograms }\end{array}$ & $\begin{array}{c}\text { Cobalt } \\
\text { mass, in } \\
\text { kilograms }\end{array}$ & $\begin{array}{l}\text { Lithium } \\
\text { mass, in } \\
\text { kilograms }\end{array}$ & $\begin{array}{c}\text { Nickel } \\
\text { mass, in } \\
\text { kilograms }\end{array}$ \\
\hline \multirow[t]{8}{*}{1996} & $\mathrm{NiCd}$ & $3,700,000$ & 22 & 1.4 & 0 & 35 & 82,000 & 5,100 & $\mathrm{XX}$ & 130,000 \\
\hline & Analog & $1,800,000$ & 22 & 1.4 & 0 & 35 & 41,000 & 2,600 & $X X$ & 64,000 \\
\hline & Digital & $1,900,000$ & 22 & 1.4 & 0 & 35 & 41,000 & 2,600 & $X X$ & 65,000 \\
\hline & NiMH & 18,000 & 0 & 3.4 & 0 & NA & XX & 62 & XX & 1,000 \\
\hline & Analog & 18,000 & 0 & 3.4 & 0 & 57 & $\mathrm{XX}$ & 62 & $X X$ & 1,000 \\
\hline & Li-ion & 0 & 0 & NA & NA & 0 & XX & 0 & 0 & XX \\
\hline & Analog & 0 & 0 & 27 & 3.3 & 0 & $\mathrm{XX}$ & 0 & 0 & $\mathrm{XX}$ \\
\hline & Digital & 0 & 0 & 7.3 & 2.2 & 0 & XX & 0 & 0 & $\mathrm{XX}$ \\
\hline \multirow[t]{8}{*}{1997} & $\mathrm{NiCd}$ & $2,800,000$ & 22 & 1.4 & 0 & 35 & 68,000 & 3,900 & $X X$ & 98,000 \\
\hline & Analog & $1,800,000$ & 22 & 1.4 & 0 & 35 & 40,000 & 2,500 & XX & 63,000 \\
\hline & Digital & 990,000 & 22 & 1.4 & 0 & 35 & 28,000 & 1,400 & $X X$ & 35,000 \\
\hline & NiMH & 36,000 & 0 & 3.4 & 0 & NA & $\mathrm{XX}$ & 120 & $\mathrm{XX}$ & 2,100 \\
\hline & Analog & 36,000 & 0 & 3.4 & 0 & 19 & XX & 120 & XX & 2,100 \\
\hline & Li-ion & 690,000 & 0 & NA & NA & 0 & XX & 5,000 & 1,500 & XX \\
\hline & Analog & 0 & 0 & 27 & 3.3 & 0 & $\mathrm{XX}$ & 0 & 0 & XX \\
\hline & Digital & 690,000 & 0 & 7.3 & 2.2 & 0 & XX & 5,000 & 1,500 & XX \\
\hline \multirow[t]{8}{*}{1998} & $\mathrm{NiCd}$ & $2,000,000$ & 22 & 1.4 & 0 & 35 & 45,000 & 2,800 & XX & 71,000 \\
\hline & Analog & $1,700,000$ & 22 & 1.4 & 0 & 35 & 37,000 & 2,300 & XX & 58,000 \\
\hline & Digital & 350,000 & 22 & 1.4 & 0 & 35 & 7,800 & 500 & $\mathrm{XX}$ & 12,000 \\
\hline & NiMH & 54,000 & 0 & 3.4 & 0 & NA & XX & 180 & XX & 3,000 \\
\hline & Analog & 54,000 & 0 & 3.4 & 0 & 19 & XX & 180 & XX & 3,000 \\
\hline & Li-ion & $1,800,000$ & 0 & NA & NA & 0 & XX & 14,000 & 3,900 & XX \\
\hline & Analog & 71,000 & 0 & 27 & 3.3 & 0 & XX & 1,900 & 240 & $\mathrm{XX}$ \\
\hline & Digital & $1,700,000$ & 0 & 7.3 & 2.2 & 0 & XX & 12,000 & 3,700 & XX \\
\hline \multirow[t]{8}{*}{1999} & $\mathrm{NiCd}$ & $1,800,000$ & 22 & 1.4 & 0 & 35 & 38,000 & 2,400 & XX & 60,000 \\
\hline & Analog & $1,600,000$ & 22 & 1.4 & 0 & 35 & 35,000 & 2,200 & XX & 56,000 \\
\hline & Digital & 140,000 & 22 & 1.4 & 0 & 35 & 3,100 & 190 & $\mathrm{XX}$ & 4,800 \\
\hline & NiMH & 80,000 & 0 & 3.4 & 0 & NA & XX & 280 & $X X$ & 4,800 \\
\hline & Analog & 80,000 & 0 & 3.4 & 0 & 19 & $\mathrm{XX}$ & 280 & XX & 4,800 \\
\hline & Li-ion & $3,000,000$ & 0 & NA & NA & 0 & $\mathrm{XX}$ & 31,000 & 7,100 & XX \\
\hline & Analog & 440,000 & 0 & 27 & 3.3 & 0 & XX & 12,000 & 1,500 & XX \\
\hline & Digital & $2,600,000$ & 0 & 7.3 & 2.2 & 0 & XX & 19,000 & 5,600 & XX \\
\hline \multirow[t]{8}{*}{2000} & $\mathrm{NiCd}$ & $1,800,000$ & 22 & 1.4 & 0 & 35 & 41,000 & 2,500 & XX & 64,000 \\
\hline & Analog & $1,700,000$ & 22 & 1.4 & 0 & 35 & 37,000 & 2,300 & XX & 58,000 \\
\hline & Digital & 160,000 & 22 & 1.4 & 0 & 35 & 3,500 & 220 & $X X$ & 5,500 \\
\hline & NiMH & 120,000 & 0 & 3.4 & 0 & NA & XX & 420 & $\mathrm{XX}$ & 7,000 \\
\hline & Analog & 120,000 & 0 & 3.4 & 0 & 19 & XX & 420 & XX & 7,000 \\
\hline & Li-ion & $3,700,000$ & 0 & NA & NA & 0 & $\mathrm{XX}$ & 40,000 & 8,700 & XX \\
\hline & Analog & 690,000 & 0 & 27 & 3.3 & 0 & XX & 19,000 & 2,300 & $\mathrm{XX}$ \\
\hline & Digital & $3,000,000$ & 0 & 7.3 & 2.2 & 0 & $\mathrm{XX}$ & 22,000 & 6,400 & $\mathrm{XX}$ \\
\hline \multirow[t]{8}{*}{2001} & $\mathrm{NiCd}$ & $1,800,000$ & 22 & 1.4 & 0 & 35 & 40,000 & 2,500 & XX & 63,000 \\
\hline & Analog & $1,700,000$ & 22 & 1.4 & 0 & 35 & 37,000 & 2,300 & $X X$ & 59,000 \\
\hline & Digital & 140,000 & 22 & 1.4 & 0 & 35 & 3,000 & 190 & $X X$ & 4,800 \\
\hline & NiMH & 160,000 & 0 & 3.4 & 0 & NA & XX & 520 & $X X$ & 8,800 \\
\hline & Analog & 160,000 & 0 & 3.4 & 0 & 19 & $\mathrm{XX}$ & 520 & XX & 8,800 \\
\hline & Li-ion & $3,400,000$ & 0 & NA & NA & 0 & $\mathrm{XX}$ & 40,000 & 8,100 & $\mathrm{XX}$ \\
\hline & Analog & 780,000 & 0 & 27 & 3.3 & 0 & XX & 21,000 & 2,600 & $X X$ \\
\hline & Digital & $2,600,000$ & 0 & 7.3 & 2.2 & 0 & XX & 19,000 & 5,500 & XX \\
\hline \multirow[t]{8}{*}{2002} & $\mathrm{NiCd}$ & $1,800,000$ & 22 & 1.4 & 0 & 35 & 41,000 & 2,600 & XX & 65,000 \\
\hline & Analog & $1,700,000$ & 22 & 1.4 & 0 & 35 & 39,000 & 2,400 & XX & 60,000 \\
\hline & Digital & 130,000 & 22 & 1.4 & 0 & 35 & 2,000 & 190 & $X X$ & 4,700 \\
\hline & NiMH & 170,000 & 0 & 3.4 & 0 & NA & XX & 570 & $X X$ & 9,600 \\
\hline & Analog & 170,000 & 0 & 3.4 & 0 & 19 & $\mathrm{XX}$ & 570 & XX & 9,600 \\
\hline & Li-ion & $4,200,000$ & 0 & NA & NA & 0 & XX & 49,000 & 10,000 & $\mathrm{XX}$ \\
\hline & Analog & 970,000 & 0 & 27 & 3.3 & 0 & $\mathrm{XX}$ & 26,000 & 3,200 & $X X$ \\
\hline & Digital & $3,200,000$ & 0 & 7.3 & 2.2 & 0 & $\mathrm{XX}$ & 23,000 & 6,900 & $\mathrm{XX}$ \\
\hline
\end{tabular}


Table A-8. Material content assumptions for selected metals and materials in batteries designated for video cameras (camcorders), by year.-Continued

[Li-ion, lithium-ion battery; NA, Not available; XX, Not applicable; NiCd, nickel-cadmium battery; NiMH, nickel-metal-hydride battery. Estimates were derived from U.S. International Trade Commission data and material distribution data provided by Pillot (2004, p. 27, 30 ). Values may not add to totals shown owing to rounding]

\begin{tabular}{|c|c|c|c|c|c|c|c|c|c|c|}
\hline Year & Cell type & $\begin{array}{c}\text { Number of } \\
\text { units }\end{array}$ & $\begin{array}{l}\text { Cadmium } \\
\text { mass, in } \\
\text { grams per } \\
\text { pack }\end{array}$ & $\begin{array}{c}\text { Cobalt } \\
\text { mass, in } \\
\text { grams per } \\
\text { pack }\end{array}$ & $\begin{array}{c}\text { Lithium } \\
\text { mass, in } \\
\text { grams per } \\
\text { pack }\end{array}$ & $\begin{array}{c}\text { Nickel } \\
\text { mass, in } \\
\text { grams per } \\
\text { pack }\end{array}$ & $\begin{array}{l}\text { Cadmium } \\
\text { mass, in } \\
\text { kilograms }\end{array}$ & $\begin{array}{c}\text { Cobalt } \\
\text { mass, in } \\
\text { kilograms }\end{array}$ & $\begin{array}{c}\text { Lithium } \\
\text { mass, in } \\
\text { kilograms }\end{array}$ & $\begin{array}{c}\text { Nickel } \\
\text { mass, in } \\
\text { kilograms }\end{array}$ \\
\hline \multirow[t]{8}{*}{2003} & $\mathrm{NiCd}$ & $1,200,000$ & 22 & 1.4 & 0 & 35 & 26,000 & 1,600 & $\mathrm{XX}$ & 41,000 \\
\hline & Analog & $1,100,000$ & 22 & 1.4 & 0 & 35 & 25,000 & 1,500 & XX & 39,000 \\
\hline & Digital & 81,000 & 22 & 1.4 & 0 & 35 & 1,800 & 110 & XX & 2,000 \\
\hline & $\mathrm{NiMH}$ & 120,000 & 0 & 3.4 & 0 & NA & XX & 400 & $X X$ & 6,800 \\
\hline & Analog & 120,000 & 0 & 3.4 & 0 & 19 & $\mathrm{XX}$ & 400 & XX & 6,800 \\
\hline & Li-ion & $4,800,000$ & 0 & NA & NA & 0 & XX & 50,000 & 11,000 & XX \\
\hline & Analog & 810,000 & 0 & 27 & 3.3 & 0 & XX & 22,000 & 2,700 & XX \\
\hline & Digital & $4,000,000$ & 0 & 7.3 & 2.2 & 0 & XX & 28,000 & 8,600 & XX \\
\hline \multirow[t]{8}{*}{2004} & $\mathrm{NiCd}$ & 690 & 22 & 1.4 & 0 & 35 & 15,000 & 930 & XX & 24,000 \\
\hline & Analog & 650,000 & 22 & 1.4 & 0 & 35 & 14,000 & 870 & $\mathrm{XX}$ & 23,000 \\
\hline & Digital & 44,000 & 22 & 1.4 & 0 & 35 & 1,000 & 61 & $\mathrm{XX}$ & 1,500 \\
\hline & $\mathrm{NiMH}$ & 78,000 & 0 & 3.4 & 0 & NA & XX & 250 & $\mathrm{XX}$ & 4,200 \\
\hline & Analog & 78,000 & 0 & 3.4 & 0 & 19 & XX & 250 & $\mathrm{XX}$ & 4,200 \\
\hline & Li-ion & $4,900,000$ & 0 & NA & NA & 0 & XX & 46,000 & 11,000 & XX \\
\hline & Analog & 570,000 & 0 & 27 & 3.3 & 0 & XX & 15,000 & 1,900 & XX \\
\hline & Digital & $4,300,000$ & 0 & 7.3 & 2.2 & 0 & XX & 31,000 & 9,400 & XX \\
\hline \multirow[t]{8}{*}{2005} & $\mathrm{NiCd}$ & 320,000 & 22 & 1.4 & 0 & 35 & 6,900 & 430 & XX & 11,000 \\
\hline & Analog & 320,000 & 22 & 1.4 & 0 & 35 & 6,900 & 430 & $\mathrm{XX}$ & 11,000 \\
\hline & Digital & 0 & 22 & 1.4 & 0 & 35 & 0 & 0 & $\mathrm{XX}$ & 0 \\
\hline & $\mathrm{NiMH}$ & 44,000 & 0 & 3.4 & 0 & NA & $X X$ & 140 & $\mathrm{XX}$ & 2,400 \\
\hline & Analog & 44,000 & 0 & 3.4 & 0 & 19 & XX & 140 & XX & 2,400 \\
\hline & Li-ion & $5,600,000$ & 0 & NA & NA & 0 & $\mathrm{XX}$ & 46,000 & 12,000 & XX \\
\hline & Analog & 360,000 & 0 & 27 & 3.3 & 0 & $\mathrm{XX}$ & 9,000 & 1,200 & $\mathrm{XX}$ \\
\hline & Digital & $5,200,000$ & 0 & 7.3 & 2.2 & 0 & $\mathrm{XX}$ & 37,000 & 11,000 & $\mathrm{XX}$ \\
\hline
\end{tabular}


Table A-9. Material content assumptions for selected metals and materials in batteries designated for hybrid vehicles, by year.

[Co, cobalt; HEV, hybrid-electric vehicle; kg, kilograms; Li-ion, lithium-ion battery; NA, not available; Ni, nickel; NiMH, nickel-metal-hydride battery; \%, percent]

\begin{tabular}{|c|c|c|c|c|c|c|c|c|c|c|}
\hline \multirow{3}{*}{$\begin{array}{l}\text { Manufacturer } \\
\text { Matsushita/Panasonic } \\
\text { Sanyo Electric Co. Ltd. }\end{array}$} & \multicolumn{2}{|c|}{$\begin{array}{l}2005 \text { market share, in } \\
\text { percent }\end{array}$} & \multicolumn{2}{|c|}{$\begin{array}{l}\text { Cell mass, in grams } \\
\text { per cell }\end{array}$} & \multicolumn{2}{|c|}{ Number of cells } & \multicolumn{2}{|c|}{$\begin{array}{l}\text { Battery mass, in } \\
\text { kilograms }\end{array}$} & \multicolumn{2}{|c|}{$\begin{array}{l}\text { Nickel fraction, in } \\
\text { percent }\end{array}$} \\
\hline & & 92 & & 173 & & 228 & & 39.5 & & 35.5 \\
\hline & & 8 & & 178 & & 245 & & 43.6 & & 40 \\
\hline \multicolumn{11}{|c|}{$\begin{array}{l}\text { 2. Calculation: } 0.92 \times[39.5 \mathrm{~kg} / \text { battery } \times 35.5 \% \mathrm{Ni}]+0.08 \times[43.6 \mathrm{~kg} / \text { battery } \times 40 \% \mathrm{Ni}]=14 \mathrm{~kg} \mathrm{Ni} \\
0.92 \times[39.5 \mathrm{~kg} / \text { battery } \times 0 \% \mathrm{Co}]+0.08 \times[43.6 \mathrm{~kg} / \text { battery } \times 0.7 \% \mathrm{Co}]=24 \mathrm{~g} \mathrm{Co}\end{array}$} \\
\hline \multicolumn{11}{|l|}{ Li-ion type battery } \\
\hline Manufacturer & \multicolumn{2}{|c|}{ Market share, in percent } & \multicolumn{2}{|c|}{$\begin{array}{l}\text { Cell mass, in grams } \\
\text { per module }\end{array}$} & \multicolumn{2}{|c|}{ Number of modules } & \multicolumn{2}{|c|}{$\begin{array}{l}\text { Battery mass, in } \\
\text { kilograms }\end{array}$} & \multicolumn{2}{|c|}{$\begin{array}{l}\text { Lithium fraction, in } \\
\text { percent }\end{array}$} \\
\hline Saft/Johnson Controls & & 0 & & 8,000 & & 5 & & 40 & & 2.15 \\
\hline \multicolumn{11}{|c|}{$\begin{array}{l}\text { 3. Calculation: } 40 \mathrm{~kg} / \mathrm{battery} \times 2.15 \% \mathrm{Li}=0.86 \mathrm{~kg} \mathrm{Li} ; 40 \mathrm{~kg} / \mathrm{battery} \times 18 \% \mathrm{Co}=7.2 \mathrm{~kg} \mathrm{Co} \\
\text { 4. Hybrid vehicle sales and sales projections from selected sources }\end{array}$} \\
\hline Data source & Units $\times 1,000$ & 2002 & 2003 & 2004 & 2005 & 2006 & 2007 & 2008 & 2009 & 2010 \\
\hline \multirow{2}{*}{ NREL/Avicenne (2006) ${ }^{1}$} & World sales & NA & NA & NA & 200 & 300 & 900 & 1,200 & 1,700 & 2,050 \\
\hline & $\%$ Li-ion & NA & NA & NA & 0 & 0 & 1 & 2 & 3 & 4 \\
\hline Johnson Controls $(2006)^{2}$ & World sales & NA & 100 & 150 & 200 & 340 & 510 & 780 & 1,100 & 1,600 \\
\hline TTI. Inc. $(2006)^{3}$ & World sales & NA & NA & NA & NA & NA & NA & NA & NA & 3,000 \\
\hline Advanced Automotive $(2006)^{4}$ & World sales & NA & NA & NA & NA & 400 & NA & NA & 1,000 & NA \\
\hline \multirow{3}{*}{ Avicenne $(2005)^{5}$} & World sales & NA & NA & 160 & 320 & 550 & 860 & 1,220 & 1,650 & 2,100 \\
\hline & $\%$ Li-ion & NA & NA & NA & 0 & 0 & 0 & 2 & 3 & 5 \\
\hline & U.S. HEV sales & 61 & 81 & 166 & 190 & 240 & 370 & 500 & 650 & 800 \\
\hline Caltrans/UC Davis (2004) ${ }^{6}$ & U.S. HEV sales & NA & NA & NA & 200 & 300 & 400 & $500-700$ & $750-1,000$ & $1,200-1,500$ \\
\hline U.S. Department of Transportation ${ }^{7}$ & U.S. HEV sales & 25 & 49 & 92 & 190 & 310 & 300 & 480 & 490 & 550 \\
\hline \multicolumn{11}{|c|}{ 5. Summary estimates used in this study } \\
\hline U.S. HEV sales & & 25 & 49 & 92 & 190 & 310 & 300 & 480 & 490 & 550 \\
\hline NiMH percent of U.S. HEV sales & & 100 & 100 & 100 & 100 & 100 & 100 & 98 & 97 & 95 \\
\hline Li-ion percent of U.S. HEV sales & & 0 & 0 & 0 & 0 & 0 & 0 & 2 & 3 & 5 \\
\hline NiMH units $x 1000$ & & 25 & 49 & 92 & 190 & 310 & 300 & 470 & 470 & 520 \\
\hline Li-ion units x 1000 & & 0 & 0 & 0 & 0 & 0 & 0 & 10 & 20 & 30 \\
\hline Metric tons of contained cobalt & & 1 & 1 & 2 & 5 & 7 & 7 & 80 & 120 & 210 \\
\hline Metric tons of contained nickel & & 350 & 690 & 1,300 & 2,700 & 4,300 & 4,200 & 6,600 & 6,700 & 7,300 \\
\hline Metric tons of contained lithium & & 0 & 0 & 0 & 0 & 0 & 0 & 8 & 13 & 24 \\
\hline
\end{tabular}

${ }^{6} \mathrm{Cao}$ and Mokhtarian (2004). $\quad{ }^{7}$ U.S. Department of Transportation (2006). 
Table A-10. Harmonized Tariff Schedule (HTS) classes applied to selected end uses of nickel-cadmium batteries for this study.

\begin{tabular}{|c|c|c|c|}
\hline Battery class (based on end use) & $\begin{array}{l}\text { HTS numbers } \\
\text { applied to this } \\
\text { battery } \\
\text { classification }\end{array}$ & $\begin{array}{c}\text { Years } \\
\text { classification } \\
\text { was used }\end{array}$ & $\begin{array}{l}\text { Trade source } \\
\text { (import or } \\
\text { export) }\end{array}$ \\
\hline \multicolumn{4}{|l|}{ Storage batteries, separate: } \\
\hline Electrically-powered vehicle batteries & 8507304000 & 1996-2005 & Import \\
\hline \multirow[t]{3}{*}{ Sealed consumer batteries } & 8507308010 & 1996-2005 & Import \\
\hline & 8507300050 & 1996 & Export \\
\hline & 8507300000 & 1997-2005 & Export \\
\hline Industrial batteries & 8507308090 & 1996-2005 & Import \\
\hline \multicolumn{4}{|l|}{ Batteries enclosed in products: } \\
\hline \multirow{2}{*}{ Power tools } & 8508100010 & 1996-2001 & Import/Export \\
\hline & 8467210010 & $2002-2005$ & Import/Export \\
\hline Cordless phones & 8517110000 & 1996-2005 & Import/Export \\
\hline \multirow[t]{4}{*}{ Camcorders } & 8525408020 & $1997-2005$ & Import/Export \\
\hline & 8525400020 & 1996-1997 & Import \\
\hline & 8525408050 & $1997-2005$ & Import/Export \\
\hline & 8525400050 & 1996-1997 & Import \\
\hline \multirow[t]{4}{*}{ Cameras } & 8525400000 & 1996-1998 & Export \\
\hline & 8525400090 & 1996-1997 & Import \\
\hline & 8525404000 & 1997-1999 & Import/Export \\
\hline & 8525408085 & $1997-1999$ & Import/Export \\
\hline Portable radios & 8527120000 & 1996-2005 & Import/Export \\
\hline Shavers & 8510100000 & 1996-2005 & Import/Export \\
\hline Electric toothbrushes & 8509800045 & $1996-2005$ & Import \\
\hline Portable vacuum cleaners & 8509100020 & $1996-2005$ & Import/Export \\
\hline Flashlights & 8513102000 & 1996-2005 & Import \\
\hline \multirow[t]{2}{*}{ Portable electric lamps (bicycle lamps, for example) } & 8513104000 & $1996-2005$ & Import \\
\hline & 8513100000 & 1996-2005 & Export \\
\hline Watch batteries, reported separately & 9101110000 & 1996-2005 & Export \\
\hline \multirow[t]{24}{*}{ Clock batteries, reported separately } & 9103100000 & $1996-2005$ & Export \\
\hline & 9103102020 & 1996-2005 & Import \\
\hline & 9103102040 & 1996-2005 & Import \\
\hline & 9103104030 & 1996-2005 & Import \\
\hline & 9103104060 & $1996-2005$ & Import \\
\hline & 9103108030 & 1996-2005 & Import \\
\hline & 9103108060 & 1996-2005 & Import \\
\hline & 9105114030 & 1996-2005 & Import \\
\hline & 9105114050 & 1996-2005 & Import \\
\hline & 9105108040 & 1996-2005 & Import \\
\hline & 9105118070 & $1996-2005$ & Import \\
\hline & 9105214030 & 1996-2005 & Import \\
\hline & 9105218050 & 1996-2005 & Import \\
\hline & 9105914030 & $1996-2005$ & Import \\
\hline & 9105918050 & 1996-2005 & Import \\
\hline & 9106905520 & 1996-2005 & Import \\
\hline & 9109111030 & $1996-2005$ & Import \\
\hline & 9109112030 & 1996-2005 & Import \\
\hline & 9109114030 & 1996-2005 & Import \\
\hline & 9109116030 & $1996-2005$ & Import \\
\hline & 9109191030 & 1996-2005 & Import \\
\hline & 9109192030 & $1996-2005$ & Import \\
\hline & 9109194030 & 1996-2005 & Import \\
\hline & 9109196030 & $1996-2005$ & Import \\
\hline \multirow[t]{7}{*}{ Military batteries, reported separately } & 9104000000 & 1996-2005 & Export \\
\hline & 9104000520 & $1996-2005$ & Import \\
\hline & 9104001020 & 1996-2005 & Import \\
\hline & 9104002520 & 1996-2005 & Import \\
\hline & 9104003020 & 1996-2005 & Import \\
\hline & 9104004520 & 1996-2005 & Import \\
\hline & 9104005030 & $1996-2005$ & Import \\
\hline
\end{tabular}


Table A-11. Harmonized Tariff Schedule of the United States (HTS) classes applied to selected end uses of lithium-ion and nickel-metal-hydride batteries for this study.

\begin{tabular}{|c|c|c|c|c|}
\hline General battery class ${ }^{1}$ & Specific battery class (based on end use) ${ }^{1}$ & $\begin{array}{l}\text { HTS number } \\
\text { applied to } \\
\text { this battery } \\
\text { class }\end{array}$ & $\begin{array}{l}\text { Years HTS } \\
\text { class used }\end{array}$ & $\begin{array}{c}\text { Trade source } \\
\text { (import or export) }\end{array}$ \\
\hline Lithium batteries, separate & Primary batteries, lithium & 8506500000 & $1996-2005$ & Import and export \\
\hline Lithium storage batteries, separate & $\begin{array}{l}\text { Rechargeable storage batteries used as the } \\
\text { primary source of electrical power for electrically- } \\
\text { powered vehicles of subheading } 8703.90\end{array}$ & 8507804000 & 1996-2005 & Import \\
\hline $\begin{array}{l}\text { Lithium storage batteries, separate } \\
\text { (rechargeable) }\end{array}$ & $\begin{array}{l}\text { Other storage batteries, not otherwise specified or } \\
\text { indicated (NESOI) }\end{array}$ & 8507800000 & 1996-2005 & Export \\
\hline Do. & Other storage batteries, NESOI & 8507808000 & 1996-2005 & Import \\
\hline $\begin{array}{l}\text { Enclosed in electrically-powered } \\
\text { vehicles }\end{array}$ & Passenger motor vehicles, NESOI & 8703900000 & 1996-2005 & Import and export \\
\hline Enclosed in cell phones & $\begin{array}{l}\text { Radio telephones designed for the public cellular } \\
\text { radio telecommunication service, weighing } 1 \\
\text { kilogram }(\mathrm{kg}) \text { or under }\end{array}$ & 8525209070 & 1996-2005 & Import and export \\
\hline Enclosed in portable computers & $\begin{array}{l}\text { Portable digital ADP machine weighing not more } \\
\text { than } 10 \mathrm{~kg} \text {, consisting of at least a CPU, keyboard, } \\
\text { and display unit }\end{array}$ & 8471300000 & 1996-2005 & Import and export \\
\hline $\begin{array}{l}\text { Enclosed in video cameras } \\
\text { (camcorders) }\end{array}$ & Camcorders, 8 millimeter $(\mathrm{mm})$, analog & 8525408020 & 1996-2005 & Import and export \\
\hline Do. & Camcorders, color, 8 mm, analog & 8525400020 & 1996-1997 & Import \\
\hline Do. & Camcorders, other than $8 \mathrm{~mm}$, digital & 8525408050 & 1997-2005 & Import and export \\
\hline Do. & Camcorders, color, other than $8 \mathrm{~mm}$, digital & 8525400050 & 1996-1997 & Import \\
\hline Enclosed in digital cameras & Still image video cameras & 8525400090 & 1996-1997 & Import \\
\hline Do. & $\begin{array}{l}\text { Still image video cameras and other video camera } \\
\text { recorders }\end{array}$ & 8525400000 & 1996-1998 & Export \\
\hline Do. & Digital still image video cameras & 8525404000 & 1997-2005 & Import and export \\
\hline Do. & Still image video cameras, NESOI & 8525408085 & 1997-2005 & Import and export \\
\hline Clock batteries, reported separately & $\begin{array}{l}\text { Batteries for travel clocks, battery powered with } \\
\text { opto-electronic display, excluding subheading } 9104\end{array}$ & 9103102020 & 1996-2005 & Import \\
\hline Do. & $\begin{array}{l}\text { Clocks with watch movements, electrically } \\
\text { operated, excluding subheading } 9104\end{array}$ & 9103100000 & 1996-2005 & Export \\
\hline Do. & $\begin{array}{l}\text { Batteries for clocks, except travel clocks, battery } \\
\text { powered, with opto-electronic display, excluding } \\
\text { subheading } 9104\end{array}$ & 9103102040 & 1996-2005 & Import \\
\hline Do. & $\begin{array}{l}\text { Batteries for clocks, battery powered, having no } \\
\text { jewels or only one jewel in the movement, } \\
\text { excluding subheading } 9104\end{array}$ & 9103104030 & 1996-2005 & Import \\
\hline Do. & $\begin{array}{l}\text { Batteries for clocks, except travel clocks, battery } \\
\text { powered, having no jewels or only one jewel in the } \\
\text { movement, excluding subheading } 9104\end{array}$ & 9103104060 & 1996-2005 & Import \\
\hline Do. & Batteries for travel clocks, battery powered, NESOI & 9103108030 & 1996-2005 & Import \\
\hline Do. & $\begin{array}{l}\text { Batteries for clocks, except travel clocks, battery } \\
\text { powered, NESOI }\end{array}$ & 9103108060 & 1996-2005 & Import \\
\hline Do. & $\begin{array}{l}\text { Batteries for travel alarm clocks, battery powered, } \\
\text { with opto-electronic display }\end{array}$ & 9105114030 & 1996-2005 & Import \\
\hline Do. & Alarm clocks, battery powered & 9105100000 & 1996-2005 & Export \\
\hline Do. & $\begin{array}{l}\text { Batteries for alarm clocks, except travel, battery } \\
\text { powered with opto-electronic display }\end{array}$ & 9105114050 & 1996-2005 & Import \\
\hline Do. & $\begin{array}{l}\text { Batteries for travel alarm clocks, with opto- } \\
\text { electronic display }\end{array}$ & 9105118040 & 1996-2005 & Import \\
\hline Do. & $\begin{array}{l}\text { Batteries for alarm clocks, except travel, battery } \\
\text { powered, with opto-electronic display }\end{array}$ & 9105118070 & 1996-2005 & Import \\
\hline Do. & $\begin{array}{l}\text { Batteries for wall clocks, battery powered, with opto- } \\
\text { electronic display }\end{array}$ & 9105214030 & 1996-2005 & Import \\
\hline Do. & Wall clocks, battery powered & 9105210000 & 1996-2005 & Export \\
\hline Do. & $\begin{array}{l}\text { Batteries for wall clocks, battery powered, with opto- } \\
\text { electronic display }\end{array}$ & 9105218050 & 1996-2005 & Import \\
\hline Do. & $\begin{array}{l}\text { Batteries for other clocks, battery powered, with } \\
\text { opto-electronic display only }\end{array}$ & 9105914030 & 1996-2005 & Import \\
\hline
\end{tabular}


Table A-11. Harmonized Tariff Schedule of the United States (HTS) classes applied to selected end uses of lithium-ion and nickel-metal-hydride batteries for this study.-Continued

\begin{tabular}{|c|c|c|c|c|}
\hline General battery class ${ }^{1}$ & Specific battery class (based on end use) ${ }^{1}$ & $\begin{array}{l}\text { HTS number } \\
\text { applied to } \\
\text { this battery } \\
\text { class }\end{array}$ & $\begin{array}{l}\text { Years HTS } \\
\text { class used }\end{array}$ & $\begin{array}{c}\text { Trade source } \\
\text { (import or export) }\end{array}$ \\
\hline $\begin{array}{l}\text { Clock batteries, reported separately } \\
\text { (continued) }\end{array}$ & Other clocks, battery powered & 9105910000 & $1996-2005$ & Export \\
\hline Do. & $\begin{array}{l}\text { Batteries for other clocks, battery powered, except } \\
\text { opto-electronic display }\end{array}$ & 9105918050 & 1996-2005 & Import \\
\hline Do. & $\begin{array}{l}\text { Batteries for device with opto-electronic display for } \\
\text { measuring, recording time, battery powered }\end{array}$ & 9106905520 & 1996-2005 & Import \\
\hline Do. & Other time of day device, NESOI & 9106900000 & 1996-2005 & Export \\
\hline Do. & $\begin{array}{l}\text { Batteries for clock movements of alarm clocks, } \\
\text { complete and assembled, battery powered, with } \\
\text { opto-electronic display only }\end{array}$ & 9109111030 & 1996-2005 & Import \\
\hline Do. & $\begin{array}{l}\text { Clock movements of alarm clocks, complete and } \\
\text { assembled, battery powered }\end{array}$ & 9109110000 & 1996-2005 & Export \\
\hline Do. & $\begin{array}{l}\text { Batteries for clock movements of alarm clocks, } \\
\text { complete and assembled, battery powered, } \\
\text { measuring not over } 50 \mathrm{~mm} \text { in width or diameter }\end{array}$ & 9109112030 & 1996-2005 & Import \\
\hline Do. & $\begin{array}{l}\text { Batteries for clock movements of alarm clocks, } \\
\text { complete and assembled, battery powered, } \\
\text { measuring over } 50 \mathrm{~mm} \text { in width or diameter, value } \\
\text { not over } \$ 5 \text { each }\end{array}$ & 9109114030 & 1996-2005 & Import \\
\hline Do. & $\begin{array}{l}\text { Batteries for clock movements of alarm clocks, } \\
\text { complete and assembled, battery powered, } \\
\text { measuring over } 50 \mathrm{~mm} \text { in width or diameter, valued } \\
\text { over } \$ 5 \text { each }\end{array}$ & 9109116030 & 1996-2005 & Import \\
\hline Do. & $\begin{array}{l}\text { Batteries for clock movements, complete and } \\
\text { assembled, except for alarm clocks, battery } \\
\text { powered, with opto-electronic display only }\end{array}$ & 9109191030 & 1996-2005 & Import \\
\hline Do. & $\begin{array}{l}\text { Clock movements, complete and assembled, } \\
\text { electronically powered, except for alarm clocks, } \\
\text { NESOI }\end{array}$ & 9109190000 & 1996-2005 & Export \\
\hline Do. & $\begin{array}{l}\text { Batteries for clock movements, complete and } \\
\text { assembled, except for alarm clocks, battery } \\
\text { powered, measuring not over } 50 \mathrm{~mm} \text { in width or } \\
\text { diameter }\end{array}$ & 9109192030 & 1996-2005 & Import \\
\hline Do. & $\begin{array}{l}\text { Batteries for clock movements, complete and } \\
\text { assembled, except for alarm clocks, battery } \\
\text { powered, measuring over } 50 \mathrm{~mm} \text { in width or } \\
\text { diameter, valued not over } \$ 5 \text { each }\end{array}$ & 9109194030 & 1996-2005 & Import \\
\hline Do. & $\begin{array}{l}\text { Batteries for clock movements, complete and } \\
\text { assembled, except for alarm clocks, battery } \\
\text { powered, measuring over } 50 \mathrm{~mm} \text { in width or } \\
\text { diameter, valued over } \$ 5 \text { each }\end{array}$ & 9109196030 & 1996-2005 & Import \\
\hline $\begin{array}{l}\text { Batteries for military application, } \\
\text { reported separately }\end{array}$ & $\begin{array}{l}\text { Batteries for instrument panel clocks, with clock } \\
\text { movements measuring over } 50 \text { mm in width or } \\
\text { diameter, valued not over } \$ 10 \text {, with opto-electronic } \\
\text { display only }\end{array}$ & 9104000520 & 1996-2005 & Import \\
\hline Do. & $\begin{array}{l}\text { Batteries for military application, reported } \\
\text { separately }\end{array}$ & 9104000000 & 1996-2005 & Export \\
\hline Do. & $\begin{array}{l}\text { Batteries for instrument panel clocks and similar for } \\
\text { vehicles, aircraft, spacecraft, measuring over } 50 \\
\mathrm{~mm} \text { in width or diameter, valued not over } \$ 10 \text {, } \\
\text { including battery }\end{array}$ & 9104001020 & 1996-2005 & Import \\
\hline Do. & $\begin{array}{l}\text { Batteries for instrument panel clocks and similar for } \\
\text { vehicles, aircraft, spacecraft, or vessel, measuring } \\
\text { over } 50 \mathrm{~mm} \text { in width or diameter, valued over } \$ 10 \text {, } \\
\text { with opto-electronic display }\end{array}$ & 9104002520 & 1996 & Import \\
\hline Do. & Batteries for instrument panel clocks and similar for & 9104003020 & 1996-2005 & Import \\
\hline
\end{tabular}


Table A-11. Harmonized Tariff Schedule of the United States (HTS) classes applied to selected end uses of lithium-ion and nickel-metal-hydride batteries for this study.-Continued

\begin{tabular}{|c|c|c|c|c|}
\hline General battery class ${ }^{1}$ & Specific battery class (based on end use) ${ }^{1}$ & $\begin{array}{l}\text { HTS number } \\
\text { applied to } \\
\text { this battery } \\
\text { class } \\
\end{array}$ & $\begin{array}{l}\text { Years HTS } \\
\text { class used }\end{array}$ & $\begin{array}{l}\text { Trade source } \\
\text { (import or export) }\end{array}$ \\
\hline $\begin{array}{l}\text { Watch batteries, reported } \\
\text { separately }\end{array}$ & $\begin{array}{l}\text { Batteries for instrument panel clocks and similar for } \\
\text { vehicles, aircraft, spacecraft, or vessel, with opto- } \\
\text { electronic display, NESOI }\end{array}$ & 9104004520 & $1996-2005$ & Import \\
\hline Do. & $\begin{array}{l}\text { Batteries for instrument panel clocks and similar for } \\
\text { vehicles, aircraft, spacecraft, or vessel, measuring } \\
\text { over } 50 \mathrm{~mm} \text { in width or diameter, valued over } \$ 10 \text {, } \\
\text { electric including battery, NESOI }\end{array}$ & 9104005030 & 1996-2005 & Export \\
\hline Do. & $\begin{array}{l}\text { Batteries for wrist watches, battery powered, with } \\
\text { cases of precious metal, with mechanical display } \\
\text { only, having no jewels or only one jewel }\end{array}$ & 9101114040 & 1996-2005 & Import \\
\hline Do. & $\begin{array}{l}\text { Wrist watches, cases of precious metal and } \\
\text { mechanical display }\end{array}$ & 9101110000 & 1996-2005 & Export \\
\hline Do. & $\begin{array}{l}\text { Batteries for wrist watches, battery powered, with } \\
\text { cases of precious metal, mechanical display only, } \\
\text { with more than one jewel }\end{array}$ & 9101118040 & 1996-2005 & Import \\
\hline Do. & $\begin{array}{l}\text { Batteries for wrist watches, battery powered, with } \\
\text { cases of precious metal, having no jewels or only } \\
\text { one jewel, NESOI }\end{array}$ & 9101194040 & 1996-2005 & Import \\
\hline Do. & $\begin{array}{l}\text { Wrist watches, with cases of precious metal, } \\
\text { NESOI }\end{array}$ & 9101190000 & 1996-2005 & Export \\
\hline Do. & $\begin{array}{l}\text { Batteries for wrist watches, battery powered, with } \\
\text { cases of precious metal, having more than one } \\
\text { jewel, NESOI }\end{array}$ & 9101198040 & 1996-2005 & Import \\
\hline Do. & $\begin{array}{l}\text { Batteries for wrist watches, battery powered, with } \\
\text { mechanical display only, having no jewels or one } \\
\text { jewel, with band of base metal with gold/silver case }\end{array}$ & 9102111040 & 1996-2005 & Import \\
\hline Do. & $\begin{array}{l}\text { Wrist watches, battery powered, mechanical } \\
\text { display only, with cases of base metal }\end{array}$ & 9102110000 & 1996-2005 & Export \\
\hline Do. & $\begin{array}{l}\text { Batteries for wrist watches, battery powered, with } \\
\text { mechanical display only, having no jewels or one } \\
\text { jewel, with band of textile or with base metal case }\end{array}$ & 9102112540 & 1996-2005 & Import \\
\hline Do. & $\begin{array}{l}\text { Batteries for wrist watches, battery powered, with } \\
\text { mechanical display only, having no jewels or one } \\
\text { jewel, with gold/silver-plated case }\end{array}$ & 9102113040 & 1996-2005 & Import \\
\hline Do. & $\begin{array}{l}\text { Batteries for wrist watches, battery powered, with } \\
\text { mechanical display only, having more than one } \\
\text { jewel, with base metal case }\end{array}$ & 9102114540 & 1996-2005 & Import \\
\hline Do. & $\begin{array}{l}\text { Batteries for wrist watches, battery powered, with } \\
\text { mechanical display only, having more than one } \\
\text { jewel, with band of textile or base metal, gold/silver- } \\
\text { plated case }\end{array}$ & 9102115040 & 1996-2005 & Import \\
\hline Do. & $\begin{array}{l}\text { Batteries for wrist watches, battery powered, with } \\
\text { mechanical display only, having more than one } \\
\text { jewel, with band of textile or base metal, base } \\
\text { metal case }\end{array}$ & 9102116540 & 1996-2005 & Import \\
\hline Do. & $\begin{array}{l}\text { Batteries for wrist watches, battery powered, with } \\
\text { mechanical display only, having more than one } \\
\text { jewel, with gold/silver-plated case }\end{array}$ & 9102117040 & 1996-2005 & Import \\
\hline Do. & $\begin{array}{l}\text { Batteries for wrist watches, battery powered, with } \\
\text { mechanical display only, having more than one } \\
\text { jewel, with base metal case, NESOI }\end{array}$ & 9102119540 & 1996-2005 & Import \\
\hline Do. & $\begin{array}{l}\text { Batteries for wrist watches, battery powered, with } \\
\text { other display, having no jewels or one jewel, with } \\
\text { band of textile or base metal }\end{array}$ & 9102192040 & 1996-2005 & Import \\
\hline Do. & Wrist watches, battery powered, other display, & 9102190000 & 1996-2005 & Export \\
\hline
\end{tabular}


Table A-11. Harmonized Tariff Schedule of the United States (HTS) classes applied to selected end uses of lithium-ion and nickel-metal-hydride batteries for this study.-Continued

\begin{tabular}{|c|c|c|c|c|}
\hline General battery class ${ }^{1}$ & Specific battery class (based on end use) ${ }^{1}$ & $\begin{array}{l}\text { HTS number } \\
\text { applied to } \\
\text { this battery } \\
\text { class } \\
\end{array}$ & $\begin{array}{l}\text { Years HTS } \\
\text { class used }\end{array}$ & $\begin{array}{l}\text { Trade source } \\
\text { (import or export) }\end{array}$ \\
\hline $\begin{array}{l}\text { Watch batteries, reported } \\
\text { separately (continued) }\end{array}$ & $\begin{array}{l}\text { Batteries for wrist watches, battery powered, with } \\
\text { other display, having no jewels or one jewel, } \\
\text { NESOI }\end{array}$ & 9102194040 & $1996-2005$ & Import \\
\hline Do. & $\begin{array}{l}\text { Batteries for wrist watches, battery powered, with } \\
\text { other display, having more than one jewel, with } \\
\text { band of textile or base metal }\end{array}$ & 9102196040 & 1996-2005 & Import \\
\hline Do. & $\begin{array}{l}\text { Batteries for wrist watches, battery powered, with } \\
\text { other display, having more than one jewel, NESOI }\end{array}$ & 9102198040 & 1996-2005 & Import \\
\hline Do. & $\begin{array}{l}\text { Batteries for wrist watches, battery powered, with } \\
\text { cases of precious metal, having no jewels or one } \\
\text { jewel }\end{array}$ & 9101914030 & 1996-2005 & Import \\
\hline Do. & $\begin{array}{l}\text { Other watches, with cases of precious metal, } \\
\text { battery powered, except wrist watches }\end{array}$ & 9101910000 & 1996-2005 & Export \\
\hline Do. & $\begin{array}{l}\text { Batteries for other watches, battery powered, with } \\
\text { cases of precious metal, NESOI }\end{array}$ & 9101918030 & 1996-2005 & Import \\
\hline Do. & $\begin{array}{l}\text { Batteries for other watches, battery powered, with } \\
\text { base metal case, with opto-electronic display only }\end{array}$ & 9102912020 & 1996-2005 & Import \\
\hline Do. & $\begin{array}{l}\text { Other watches, with cases of base metal, battery } \\
\text { powered, except wrist watches }\end{array}$ & 9102910000 & 1996-2005 & Export \\
\hline Do. & $\begin{array}{l}\text { Batteries for other watches, battery powered, } \\
\text { having no jewels or one jewel }\end{array}$ & 9102914030 & 1996-2005 & Import \\
\hline Do. & $\begin{array}{l}\text { Batteries for other watches, battery powered, with } \\
\text { base metal case, NESOI }\end{array}$ & 9102918030 & 1996-2005 & Import \\
\hline
\end{tabular}

${ }^{1}$ General and specific battery classification descriptions as reported by the U.S. International Trade Commission, modified where necessary for consistency. 
